1

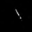





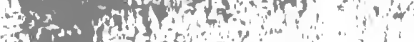
(n)

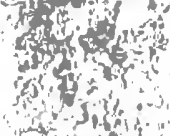
inting sidition

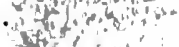

this on

A (n)

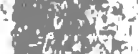
on $10=0$

ning 3 r.

(1)

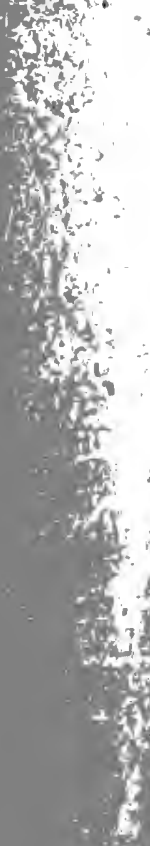
and .

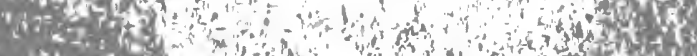

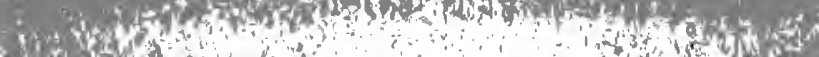


$\div$

?f

$+4 \mathrm{Cr}^{2}$

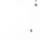


THE INTERNATIONAL TRADE BALANCE

IN

\section{THEORY AND PRACTICE}




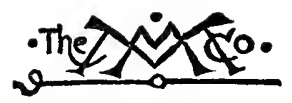

THE MACMILLAN COMPANY

NEW YORK - BOSTON - CHICAGO - DALLAS ATLANTA - SAN FRANCISCO

MACMILLAN \& CO., LMITED

LONDON - BOMBAY - CALCUTTA

MELBOURNE

THE MACMILLAN CO. OF CANADA, Lm. TORONTO 


\section{EcL
B6747i}

\section{THE INTERNATIONAL TRADE BALANCE IN}

THEORY AND PRACTICE

\section{BY \\ THEODORE H. BOGGS, Ph.D.}

PROFESSOR OF ECONOMICS IN THE UNIVERSITY OF BRITISH COLUMBIA

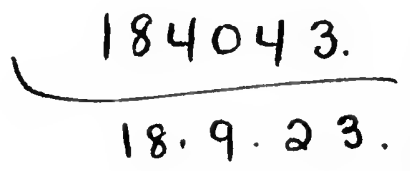

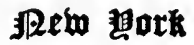 \\ THE MACMILLAN COMPANY \\ 1922}


PRINTED IN THE UNITED STATES OF AMERICA

COPYRIGHT, 1922,

BY THE MACMILLAN COMPANY.

Set up and printed. Published October, 1822.

Press of

J. J. Little \& Ives Company

New York, U. B. A. 
To

THE MEMORY OF

MY WIFE 
Digitized by the Internet Archive in 2007 with funding from Microsoft Corporation 


\section{PREFACE}

A natural and inevitable result of the vast warinduced lending and borrowing operations of recent years has been a greater popular interest in the nature and significance of the international equation of indebtedness. The question of the balance of trade had formerly but a limited appeal. It was believed to concern few other than the foreign exchange broker and the student of foreign trade. To-day it receives more general attention for the reason that its importance is far more widely recognized. Financial operations between nations are to-day conducted on so large a scale that the net position of any country as a lender or borrower may be quickly altered. A change of this nature is soon reflected in the merchandise trade balance, and this in turn serves to arrest public attention. A further factor in this new and much more widespread public interest has been the extraordinary fluctuations of foreign exchange within recent years.

This book is an attempt to set forth, with a reasonable measure of fullness, the principles underlying the theory of the balance of trade, and their practical application, as revealed in the trade 
balances of various countries. In order to facilitate a comparison of the results obtained, the writer has estimated these balances, for the several countries considered, for the same period, namely, the years 1911-13. The closely related question of foreign exchange has necessarily also received a considerable measure of attention.

The author wishes to acknowledge his personal sense of indebtedness to Professor A. G. Keller, of Yale, whose inspiration first stimulated his interest in sociology and economics. To Professor F. H. Dixon of Princeton, the late Professor G. R. Wicker of Dartmouth, Professor H. F. Angus of the University of British Columbia, and Mr. W. G. Sutcliffe, Lecturer at Simmons College, the writer is under obligation for helpful criticisms and valuable suggestions.

TheODORE H. BogGs.

\section{Vancouver, Canada, June, 1921.}




\section{CONTENTS}

CHAPTER

I. The Theory of the Balande of Trade

II. The Balance of Trade of the United

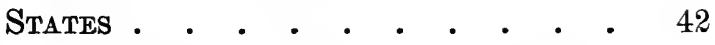

III. The Trade Balande of the United KingDOM • • • • • • • • • • • 80

IV. The Canadian Baranoe of Trade . . 119

V. The Indian Trade Balance . . . . . 159

Vi. The Balances of Trade of Australia, New Zealand, and South Africa . . . 187 



\section{INTERNATIONAL TRADE BALANCE IN THEORY AND PRACTICE}

\section{CHAPTER I}

THE THEORY OF THE BALANCE OF TRADE

The intimate relationship between foreign trade and the international ebb and flow of capital is now generally conceded. It is recognized that the commercial relations of nations comprise more than the mere exchange of commodities. The exports and imports of goods form, it is true, a major element in the aggregate of commercial transactions. Yet there are other important factors whose influence, long undetected, is now acknowledged.

Since the close of the World War the connection between foreign trade and the international movement of capital has come to enjoy a wider recognition. Many have become persuaded of the truth of the principle when confronted by the prospect of altered conditions in the foreign trade of their own country, the changes coming in large part as a result of the vast lending and borrowing operations of the war. We are beginning to see, as perhaps never before, that the foreign investment of 
capital brings in its wake many trade consequences. The axiom that "trade follows the flag" may be paraphrased to fit the present situation by saying that trade follows the foreign investment.

The important principle that finance is a pioneer of trade may be supported by evidence drawn from the experience of many countries. That of Great Britain will perhaps suffice for the purpose of illustration. Although her preëminence in international trade has been powerfully furthered by her merchant marine and extensive colonial em. pire, yet, in the final analysis, we would probably find the principal key to her commercial supremacy in the vastness of her overseas investments. British capital invested abroad has been variously estimated as amounting in 1914 to from $\$ 15,000,000,000$ to $\$ 20,000,000,000$. While functioning as a great silent factor, it none the less has served effectively to insure both imports of raw material for her industries and foreign markets for her exports. Commenting on this general principle, Sir George Paish declared, in 1909, that "the investment in the last sixty years of about $£ 2,500,000,000$ of British capital has occurred simultaneously with a vast growth of British trade and prosperity, and in my opinion this growth of our trade and prosperity is largely the result of our investment of capital in other countries." 1

Both the volume of a nation's foreign trade and

'Paish, "Great Britain's Capital Investments in Other Lands," Journal of Royal Statistical Society, September, 1909. 
the nature of its trade balance alike are affected by the international flow of capital. Generally speaking, the trade balance reflects the net position of a country as a lender of capital for overseas investment or as a borrower of foreign capital for domestic investment. This principle applies equally to countries with an excess of imports, such as the United Kingdom, France, and pre-war Germany, and to those with an excess of exports, such as the United States and the Argentine. Moreover, a nation's trade balance may in time undergo a transition to conform to changes which may appear in its position as a lender or a borrower of capital.

As generally used, the term "trade balance" is applied to a country's foreign trade in merchandise. It is used for the purpose of indicating the excess value of the merchandise exports over merchandise imports or the excess value of such imports over exports. In financial circles the term is employed to denote the condition of foreign trade which enables a country to import supplies of the precious metals, or the reverse condition which necessitates the exportation of the same.

Through the modern development of commerce and international banking we have learned to recognize the fallacy present in the "Mercantile Doctrine," so widely accepted during the sixteenth, seventeenth, and eighteenth centuries. It was then believed that a country must secure a favorable balance of trade, a balance, that is to say, of merchandise exports over imports, if it would escape 
the ruinous consequence of having its stock of the precious metals drained away. The views then current appear concisely in an essay by Josiah Tucker, the Dean of Gloucester, on the advantages and disadvantages of foreign trade, published about $1750 .^{1}$ He declared in one passage that:

"A trade may be beneficial to the nation, where the imports exceed the exports, and consequently the balance paid in specie, if that trade, directly or indirectly, is necessary for the carrying on of another more profitable and advantageous. But then it is to be observed, this trade is not beneficial considered in itself, but only as it is relative and subservient to the carrying on of another. This is the case, with respect to the greatest part of our trade to the Baltick, and the East Indies: They are instrumental in procuring a balance elsewhere, though, properly speaking, disadvantageous in themselves. Which brings the matter to the point from whence we set out; viz., 'That the science of gainful commerce consists, ultimately, in procuring a balance of gold or silver to ourselves from other nations'."

To the statesmen and financiers of that time it was accordingly a matter of supreme concern to attain and retain a balance of exports over imports. Much legislation, therefore, was passed for the purpose of restricting imports and stimulating exports. The process of estimating a country's trade relations and commercial soundness is not, however,

1 Tucker, "Essay on the Advantages and Disadvantages which respectively attend France and Great Britain in regard to Trade, with Proposals," etc. 
so simple as the mercantilist theorists supposed. They failed to see, at any rate understandingly, that the imports and exports of goods, important as they are, form but one element in the total of international exchanges. It is not, therefore, as Professor Bastable has shown, "the equivalence of imports with exports that constitutes the stable condition of trade, but the equivalence in the sum of debts due to the country, and that of debts due by it." The balance of merchandise trade became so exaggerated, in the view of the mercantilists, that the other factors were overlooked.

In modern times we have come to see, as Sir George Paish points out, "that a nation could, under certain circumstances, purchase goods of a greater aggregate value than it exported without sustaining any drain upon its stock of the precious metals or suffering any inconvenience whatsoever; and in recent time no one has paid any great amount of attention to the question of the trade balance other than for the purpose of ascertaining the factors which caused the imports of certain countries largely to exceed their exports or of discovering the reason for the exports of certain countries largely exceeding their imports." It is now recognized that a nation's foreign trade will adjust itself more or less quickly to the needs of that country and that under normal conditions the effect of some disturbing factor which may reduce temporarily its exporting ability may be counteracted by financial operations in the international 
money markets. Thus, save under the stress of some abnormal influence on the scale of the European War, little apprehension need be felt that an excessive drain can occur of the precious metals. Nevertheless, evidence still abounds that the dictum of Sir Robert Giffen that "the 'balance of trade' and 'the excess of imports over exports' are pitfalls for the amateur and unwary" has lost little of its pertinency.

Generally speaking, those countries of the world which have an excess of merchandise imports over merchandise exports are the capital-lending countries, whereas those whose exports exceed imports are the borrowing countries. This is so, because the lending country must secure payment, in the form of imports, not only for its merchandise exports, but also for the interest upon its capital invested abroad in earlier years. Similarly, if we exclude other factors from consideration, the capital-borrowing country must export more goods than it imports in order to offset the merchandise imported, as well as to meet the interest charges upon the capital which it has previously borrowed. True, during the early stages of capital investment, the lending country will normally show an excess of exports. Were these capital investments to extend over one year only, the excess of merchandise exports of the lending country during the period in question would approximately measure the amount of the capital loaned abroad. As time elapses, however, the total capital invested in 
other countries increases, although at a diminishing percentage rate, while at the same time the annual interest charges owed to the creditor nation show a more than corresponding percentage increase. Eventually the time will arrive when the annual payments which the lending country receives as interest on its foreign investments will exceed the new and additional capital which it may lend each year. The same reasoning may be employed to show that the borrowing country, during the early stages, will normally import a larger amount of merchandise than will be exported, and that here, too, the passing of time brings in its wake a change in the trade balance. Ultimately the annual interest payments of the borrowing country on account of capital previously obtained will surpass in amount the new capital which it borrows each year. Thus, in the end, its merchandise exports will overtake and then exceed its im. ports.

From the foregoing summary we note that on the basis of their capital investments and trade balances there are four general groups of countries. They are as follows:

1. Countries which have begun to invest capital abroad in other lands. These we may call the immature lending countries. Their trade will normally be marked by an excess of exports. England during the early years of the nineteenth century typified this group. At that time she regularly exported goods to a greater value than she 
imported. These represented the goods she was lending abroad. The United States, since 1917, may also be considered an immature lending country.

2. Countries which have in the past invested abroad so large a volume of capital that the annual interest payments thereon owed to them exceed the new and additional capital that they may continue to lend each year. These we may designate as mature lending countries. Their trade balance will be marked normally by an excess of imports. England for approximately a century has been the great example of this type of country. And we may anticipate that in the not remote future the United States, having become a mature lender, will find her trade balance marked also by an excess of imports.

3. Countries which are in the habit of borrowing capital from abroad, but whose volume of capital thus borrowed is not so large that the resultant annual interest charges thereon shall equal the new and additional capital that they may import each year. These countries, the immature borrowers, have trade balances marked normally by an excess of imports. Canada, prior to 1914, was in this stage of borrowing. The United States, likewise, prior to 1874 was an immature borrower.

4. Countries that have borrowed from abroad so large a volume of capital that the annual interest charges exceed in amount the new capital that they may annually procure from abroad. To such coun- 
tries we may apply the term mature borrowers. Their balance of trade will show an excess of exports. India typifies this group. The United States reached this stage about 1874, and only recently, largely as a result of the financial operations of the war, has emerged therefrom into the position of the immature lending country. Canada is now passing from the condition of an immature borrower to that of a mature borrowing country.

The above classification may perhaps be made more clear by an analogy from the field of individual investment. Let us imagine the case of an eccentric investor, A, who determines to purchase one one-hundred dollar bond of a corporation $\mathrm{X}$ each year for an indefinite period. Let us assume that the interest payable annually on the bond is at the rate of four per cent. During the first year, therefore, under these circumstances, $\mathrm{A}$ will invest $\$ 100$ in the securities of the corporation, and in turn will receive $\$ 4$ in the form of interest. During the second year A's investment again is $\$ 100$, while his interest now amounts to $\$ 8$. In the twenty-fourth year A's investment is still $\$ 100$, but his interest return has now reached $\$ 96$. From the twenty-sixth year onward the annual interest payable to $A$ is obviously larger than his new annual investment, and increasingly so.

In applying the analogy it is of course recognized that the use of the terms "mature" and "immature," as attached to investors and borrowers, is arbitrary. Yet such use, even in a restricted sense, is 
not without merit. The term "mature" is used as a convenient substitute for the clause "in the later stages," while the term "immature" implies "in the earlier stages." We may, therefore, consider our investor, A, an immature investor or lender during the first twenty-four years of the hypothetical transaction. During this period A's new annual investment exceeded the interest which he annually received. In and after the twenty-sixth year, A became a mature investor. His new investment each year was now surpassed by the annual interest received by him. It is in this sense that England is referred to above as an immature lending country during the early years of the nineteenth century, and as a mature lender in recent decades. Likewise, the status of the United States as an immature borrower prior to 1874 may be likened to the position of corporation $X$ during the first twenty-four years; a period in which the corporation borrowed, or obtained, from A, a larger amount of capital each year than the corporation was called upon to pay to $\mathbf{A}$ in the form of interest. From 1874 onward till about 1917, the United States may be looked upon as a mature borrowing country; in the same sense in which corporation $\mathrm{X}$ became a mature borrowing concern in the twentysixth year, from which time onward $\mathrm{X}$ borrowed, or obtained, from A an amount of new capital each year less in volume than the interest payable to $A$.

It is, of course, recognized that in the ebb and flow of capital internationally the process of lend- 
ing and borrowing does not proceed on so uniform and arbitrary a basis as that depicted in the above transaction. The volume of capital which a country may lend or borrow varies from year to year, and the interest rate is not uniform on all loans. And, moreover, the same country may engage in both lending and borrowing operations. Yet the essential fact remains that in the career of a lending country a time will be reached sooner or later when the new capital loaned abroad each year will be equaled and later surpassed by the amount of interest payable annually to that country on account of its earlier foreign investments. By the same form of reasoning, a point will be reached some time in the career of a borrowing country when the new annual capital borrowings will be surpassed by the volume of interest payable abroad on the capital already imported.

In view of the importance of international borrowing and lending as a factor in the determination of the balance of trade, let us consider more concretely the manner in which the lending of capital overseas works out its effects. The vast sums of capital invested by England in India, Egypt, the United States, the Argentine Republic, etc., for railway development, harbor construction, irrigation works, and other purposes are now represented by national or private debts of all kinds, such as government stocks and bonds, railway and land companies' shares, and all other forms of public and private indebtedness. 
"The method and the effect of the creation of these huge items in the balance sheet of nations are," we are reminded by Professor Todd, "of a double character. When in the first place a loan is raised in London, say for the construction of an Argentine railway, the amount of the loan is not exported in boxes of gold to the borrowing country. As a matter of fact, the bulk of the money never leaves England, but is simply placed to the credit of the foreign government or company in the books of the Bank of England, from which it is almost immediately paid out again in the form of cheques to the engineers or bridge builders who have already supplied the goods for which the loan was intended to pay. Thus the loan is given in the form of goods which appear in the customs returns of the exports of the lending country, and go to swell the statistics of exports for that year, without any corresponding entry of imports in payment therefor. There is, therefore, for the time being, an apparent excess of exports by the lending country, and a corresponding excess of imports by the borrowing country. But in subsequent years interest will require to be paid on the loan, and at some future date it must be repaid either in a lump sum or by installments spread over a period of years, and this repayment, whether of interest or capital, can only be made in the form of goods. ... Thus the effect upon the borrowing country's balance of trade is to create in the year that the loan is raised, an apparent excess of imports which is balanced by the invisible export of the debt in the form of the loan certificates. But in future years the borrowing country's exports must be in excess of its imports, to an amount sufficient to meet the interest charges on the debt, 
'which thus becomes an invisible import (of interest coupons) to that amount. Again, when the loan comes to be repaid, this also will tend to swell the exports of the debtor country for that year." 1

So far, it will be noted, we have considered in our study of trade balances but a single factor apart from trade in merchandise-namely, that of capital investments and payment of interest thereon. Were it possible to exclude all other influences, the balance of trade would be determined in accordance with the foregoing principles. There are, however, several other important factors which must be taken into account, and which will receive detailed consideration elsewhere. One of these, of great moment to Great Britain and, probably, in the future, to the United States as well, is the service of ocean transport rendered by those countries possessing great fleets of merchant ships to those which possess little or no shipping. Another class of services is that rendered by marine and other insurance companies, commission merchants, and the elaborate financial system, all of which facilitate the handling of foreign trade. Another factor, of importance to certain countries, is the item to which the term "boarding expenses" is aptly applied. This includes the expenditure of tourists and of others who have occasion to travel or live outside of their own country. Among other in-

${ }^{1}$ Todd. "The Mechanism of Exchange," p. 181. 
fluences are the ebb and flow of immigrants, the seasonal and temporary migration of workers from one country to another, and remittances by immigrants or by others.

It will be well to consider briefly the gradual evolution of ideas concerning the balance of trade. It has been stated that during the seventeenth century it was believed generally that a country should maintain an excess of merchandise exports over imports, to the end that its stock of the precious metals should be maintained if not augmented. An adverse balance, an excess of merchandise imports, was looked upon with apprehension. This attitude rested for its explanation, on the importance attached to the precious metals by the early mercantilist writers. The extraordinary importance attached to gold and silver "was perhaps justified," declares Professor William Smart, "in times when there were no bankers; when Europe was starving for a sound currency, and industry hampered by the want of it. All countries took strong measures to attract and retain gold and silver; even Spain-the depot of these metalsprohibited their export under the most drastic penalties. When in time it was seen that such measures were useless, it was conceived that there was a more natural way of effecting the same object; if encouragement were given to exports while imports were handicapped, there would tend to be a 'favorable balance'-that is, the excess of value would come in gold and silver; hence bounties on 
exports and duties on imports." 1 Referring to this policy, Adam Smith stated that "the attention of Government was turned away from guarding against the exportation of gold and silver to watch over the balance of trade as the only cause which could occasion any augmentation or diminution of these metals. From one fruitless care it was turned away to another, much more intricate, much more embarrassing, and just equally fruitless."

The mercantilist view of the balance of trade has been discarded because of the growing recognition of certain fundamental principles. In the first place, we now look upon gold as something not to be consumed, but rather as a thing or instrument for facilitating trade. No longer do we think of associating the prosperity of a country with the per capita amount of gold possessed by that country. In the second place, it is recognized that "every importation when it takes the form of a regular current, necessarily provokes and determines a corresponding exportation, and conversely." 2 This law of the balance of trade operates and exerts its influence in the first instance through the variation in the rate of foreign exchange and in the long run through its effect on general prices. We have here, therefore, two automatic checks, in the rate of exchange and general prices, which, under normal conditions, will prevent a permanent or excessive flow of gold either

${ }^{1}$ Smart, "The Return to Protection," p. 16.

"Todd, "The Mechanism of Exchange," p. 132. 
into or out of a country. As a consequence we have come to see, in the third place, that total exports and total imports of every country must approximately balance each other. The terms "total exports" and "total imports" are used advisedly. The most casual examination of the actual customs returns of exports and imports of any country will reveal the fact that they do not appear to bear out this law at all. The apparent discrepancy grows out of the practice of including among exports and imports only merchandise goods, and, at times, specie and bullion. In the ordinary statement of foreign trade no account is taken of the export and import of services, of capital, interest, boarding expenses, etc. In the interest of clearness, therefore, let us refer to these items as invisible exports and imports, as Sir Robert Giffen first called them. The term visible may quite naturally be applied to merchandise exports and imports. Now, although merchandise, or visible, exports and imports are not likely to balance for any country, we may none the less rest assured of an approximate equivalence between the total (including both visible and invisible) exports and total (both visible and invisible) imports. Under normal conditions this must inevitably be the case, on account of the operation of the automatic checks mentioned above.

Recognizing the danger of confusion that may attend the use of the terms "exports" and "imports" in this study of trade balances, and believing that the possibility of such confusion will be 
reduced through the use of the terms "credits" and "debits" the writer has in large part adopted the latter terms where ambiguity might otherwise arise. It is obvious, of course, that the reader, if he so wishes, may readily substitute the terms exports and imports as occasion demands in this and subsequent chapters.

It is perhaps scarcely necessary to emphasize the fact that both the visible and invisible factors alike have an effect upon the foreign exchange rate. An overseas investment of $\$ 500,000,000$ of capital in the course of a year would exert the same influence upon the foreign exchange situation as that imparted by the importation of $\$ 500,000,000$ worth of foreign goods. This general truth has been well put by Mr. Hartley Withers. In his explanation of the variation in the price of sterling exchange, he states that

"the only reason why anyone in New York should want to buy pounds in London is because he has payments to make on this side. He has money in hand in New York, but of course it is all in dollars, and he has to pay a debt in England, and in order to do so he must buy pounds in England with his dollars in New York, because his English creditor will, naturally, take payment only in pounds. The reasons why he may have to pay a debt in England are manifold. He may be the New York banker to a great American railroad which has a large number of its bonds or shares held in England, and has to remit hither to pay interest or dividends; or he may be an importer of English goods which he

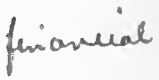


sells in America and pays for in England, or he may be the American father of an English duchess who has to remit her dowry, or he may be an Irish peasant, working and earning wages in America and sending home money to his father to help him to pay his rent. All the hundreds of reasons which make Americans pay money to England make them want to buy English money in New York with American dollars." 1

The statement above will be recalled that an equivalence of exports with imports does not in itself constitute an essential condition of stable trade, but that national commercial solvency rests instead upon an equivalence between payments by and to a country. There is a great difference generally between the balance of merchandise trade of any country and its balance of total indebtedness. In seeking to estimate a country's commercial position, therefore, attention must be directed to the balance of indebtedness; and obviously this involves in reality nothing else than an investigation of the debtor and creditor account of the country. The principal factors that appear in the international balance sheet have already been enumerated. Their position in the balance sheet may be briefly indicated. Prominent among the debit items against a country's account are merchandise imports, the interest and dividends owed abroad to foreign lenders of capital, its own capital which may be undergoing export for investment

'Withers, "War and Lombard Street," p. 41. 
abroad, freight charges due to foreign shipping companies, commissions to foreign banking and insurance companies for services rendered, and remittances and other payments which may be made abroad by immigrants and other residents within the country. Among the credits the principal elements are merchandise exports, the receipt from abroad of interest and dividends on capital already loaned and invested in other countries, the importation of foreign capital for investment within the country, the freight earnings of domestic ships, the commissions received by financial companies for services rendered abroad, and other miscellaneous payments due from other nations for a variety of reasons.

It will be well, perhaps, to offer a further word of explanation concerning the significance of loans of capital by one country to another. "The contracting of a loan by a nation makes the nations which offer the loan its debtors," Bastable states, ${ }^{1}$ "for the time being, till the loan is carried out, and it necessarily becomes their creditor. To take the most usual instance, investments of capital abroad, while being carried on, make a country a debtor, as the investment of foreign capital in a country makes it a creditor." The interest payable upon such capital, however, after it has been invested, has naturally an effect in the opposite direction. In this case, the lending or investing country is a creditor, while the country which has the interest

${ }^{1}$ Bastable, "Theory of International Trade," p. 74. 
charges to meet is a debtor. In the repayment of a loan previously incurred we find the effect to be similar to that attending the payment of interest on a loan outstanding. It is placed to the credit of the receiving country, and to the debit of the one repaying.

For support of the contention, already propounded, that the equivalence of merchandise exports and imports is not essential to commercial solvency, let us turn to the well-known fact that trade prosperity quite impartially may attend an excess of exports over imports or the reverse condition. The prosperity of the United States during the three decades preceding the World War is no more to be attributed to the excess of exports which characterized the American trade balance, than is British prosperity during the same period to be explained on the ground of an excess of imports. Moreover, a country's trade balance may undergo change in the course of time without affecting the commercial prosperity of the country. But the same is not the case with the balance of total indebtedness. A country which has against it a net balance of indebtedness must effect a modification of some of the elements in its international account, or suffer commercial losses.

Inasmuch as merchandise exports and imports, in general, are the items most easily altered or the most susceptible to change, a readjustment, therefore, will normally take effect through them. An unfavorable balance will, in the course of time, be 
discharged, through the intervention of the foreign exchange rate and general prices, in the form of reduced imports, increased exports, or a combination of both. The change which occurred about 1874 in the merchandise trade balance of the United States will serve to illustrate this principle. The excess of imports which normally marked American trade prior to 1874 was a natural resultant accompaniment of the heavy importation of foreign capital for investment in the United States. About that time, however, the annual interest and dividend charges payable to foreign lenders on earlier loans began to surpass in volume the new capital which entered the country. This prospective balance of payments against the United States was met by the readjustment in the trade balance to which reference has been made. From that time onward American trade was marked by an excess of exports, a growing excess which approximately reflected and kept pace with the increasing balance of invisible debits against the country.

A further example of the relation between foreign borrowing operations and the trade balance may be taken from the experience of the Argentine. An overturn occurred in 1891 in the trade balance of that country, when an excess of imports over exports, which till then had been the normal condition of things, was changed into an excess of exports over imports, a condition which has marked the trade of that country ever since. In the chart which follows there is depicted the relationship be- 
tween the Argentine trade balance and the volume of foreign loans contracted by that country dur-

Balance of Trade and Balance of Borrowings, 1881-1900 (Argentina) $^{1}$

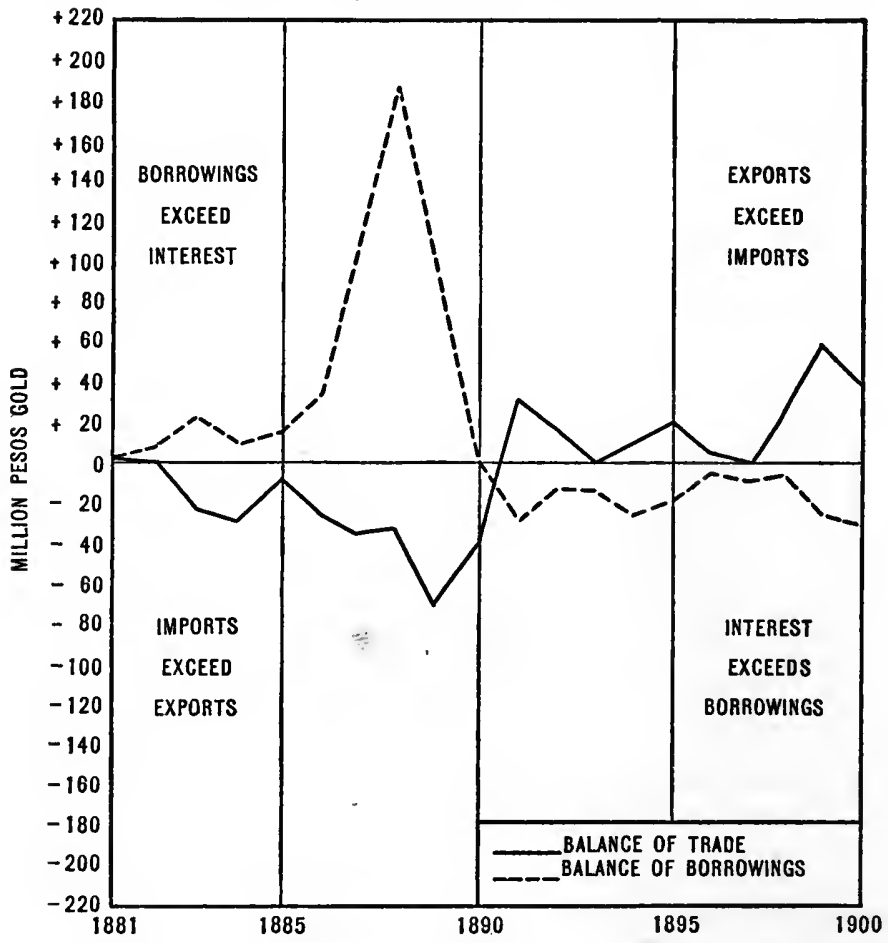

ing the last two decades of the nineteenth century. The balance of borrowings represents the difference between the volume of foreign capital in-

${ }^{1}$ Williams, "Argentine International Trade under Inconvertible Paper Money, 1880-1900," p. 186. 
vested annually in Argentina and the interest charges annually payable by that country to foreign lenders of capital. The trade balance represents exports minus imports.

It will be noted from the above chart that prior to 1890 the new annual loans from abroad exceeded the annual interest charges. During that period merchandise imports exceeded the exports. Since 1890, the case has been reversed. It is of interest to note that the transition in the balance of borrowings occurred in 1890, followed a year later by the overturn in the balance of trade. In the main, the changes in the balance of borrowings are followed very shortly by changes in the contrary direction in the trade balance.

It is, of course, true that the inconvenience of a sudden change in prices with its attendant disturbance of the merchandise trade balance may be obviated by a foreign loan. Such a loan will serve, for the time, to maintain the equation of indebtedness. Obviously, however, no nation can continue permanently to meet its foreign obligations and discharge the annual payments accruing against it by the process of incurring new debts. Eventually, it has been pointed out already, the interest charges would come to exceed the new capital annually borrowed.

Having noted that an equivalence of merchandise exports and imports is unessential, if not indeed generally non-existent, let us return to the contention that an equivalence between total credits and 
total debits, for each country, must always, under normal conditions, be approximated. The equation of indebtedness is the position toward which international trade always moves. That this is so was attributed above to the action of two socalled automatic forces-the foreign exchange rate, and international price levels. To be sure, there are certain conscious correctives which may be deliberately employed to correct the course of commerce and the exchanges, such as increasing or decreasing exports or imports, reforming the currency system, and varying the bank discount rate. While these methods are effectively employed on occasion, the fact remains that the foreign exchanges and general prices contain within them. selves a force which always tends to preserve equilibrium between the total payments to and from any country.

The mechanism of the foreign exchanges is devised to facilitate trade and financial transactions between nations. It seeks through the use of credit instruments and by the practice of offsetting claims and counter-claims to enable countries the more readily to discharge their mutual obligations. "The fluctuations which actually take place in the foreign exchanges are at once the necessary result and the certain index of the inequalities which exist in the indebtedness of different countriesinequalities either in the amount of their liabilities, or in the time within which payment must be made, or in the relation of the currency of one country to 
that of another." 1 Under normal conditions the primary cause of variations in the rate of exchange lies in the comparative amount of foreign indebtedness. In those cases, however, where an inconvertible paper circulation exists, the most important cause is found in the nature of the currencies.

In the event of divergence from equilibrium between the total credits and total debits of any country the foreign exchange rate would at once reflect the fact. Thus if merchandise imports, or any other debit item in the account, were to increase excessively the rate would rise. With this increase of the rate above par, importers in that country would at once face the necessity of paying more for goods imported from abroad. The rise in the rate would, therefore, tend to discourage imports. Obviously, too, exports would be encouraged. Quite possibly, however, this factor would not be sufficient to check the excessive buying from abroad and thus bring the rate back toward par. In this event, the rate would continue to rise until it reached the upper gold or specie point. It is at this juncture that the second automatic check would begin to function. The specie point having been reached, gold shipments would begin to be moved from the importing country.

For the purpose of illustration, let us assume that the United States and Canada are entirely cut off from commercial relations with other countries and that Canada, typifying our importing country

${ }^{1}$ Goschen, "Theory of Foreign Exchanges," pp. 4, 5. 
above, is buying heavily in the American market. Let us assume further that the Canadian people, disregarding the handicap of a heightened exchange rate, persist in their importation of American goods, that the rate of exchange on New York is forced up to the specie point, and that, in consequence, a large quantity of gold is shipped from Montreal to New York. At once Montreal bankers, finding their gold reserves reduced, would restrict credit by calling loans and granting new ones more reluctantly. New York banks, on the contrary, would be encouraged to enlarge their loans on account of their increased gold reserves. If this were continued, that is to say, if the Canadian people should still persist in buying excessively in the American market, the effect would soon be countrywide; in the United States there would be an increase in the volume of money and credit, in Canada a restriction of the same. The general price level in Canada would therefore fall, while in the United States it would rise. Obviously, as a result of these changes, Canada would now be a profitable country from which to buy and an unprofitable country to which to export. By the same token, a continuation of Canadian buying in the American market would be attended by increasingly ruinous results. Automatically, Canadian imports would be checked and exports stimulated, and the reverse movement back toward equilibrium would be initiated. The persistent tendency toward equivalence of payments to and by a country is, under normal conditions, 
based, therefore, in the first instance on the fluctuations of the rate of exchange and ultimately, if need be, on the readjustment of prices attendant upon the shipment of gold.

We are reminded by Professor Taussig that "a comparatively slight disturbance of international payments leads to a flow of specie, and sets in motion a train of forces, either in the money market in the narrower sense or in the general price market, which tend to check the flow of specie and bring about a new equilibrium." 1 In other words, so long as we have the free international movement of gold and normal conditions of trade, a rise in the exchange rate may be looked upon as a partial closing of the door through which imports flow in and a wider open door through which exports flow out. A fall in the rate would have the contrary effect. The flow of gold, under normal conditions, gives rise to its own automatic limitation.

That exchange rates normally move in sympathy with changes in the export and import trade is, of course, a commonplace. For example, in a normal year sterling exchange rates in New York move downward toward the gold import point in the autumn, in response to the heavier American exports of that season of the year. During the spring and early summer sterling rates in New York, on the contrary, rise above par and move toward the gold export point, owing to the fact that the pre-

1 Taussig, "International Trade under Depreciated Paper," Quarterly Journal of Economics, May, 1917. 
vious season's crop exports have been paid for, and the current crops have not yet been harvested. In the chart which follows there appear the results, averaged for a typical year, of a study of monthly averages of sterling sight rates in New York, from 1889 to 1919 .

Comparison of Seasonal Variation for Exports of MerchanDISE AND FOR THE RATE FOR BANKERS'

SIGH'T BILLS oN LoNDON ${ }^{1}$

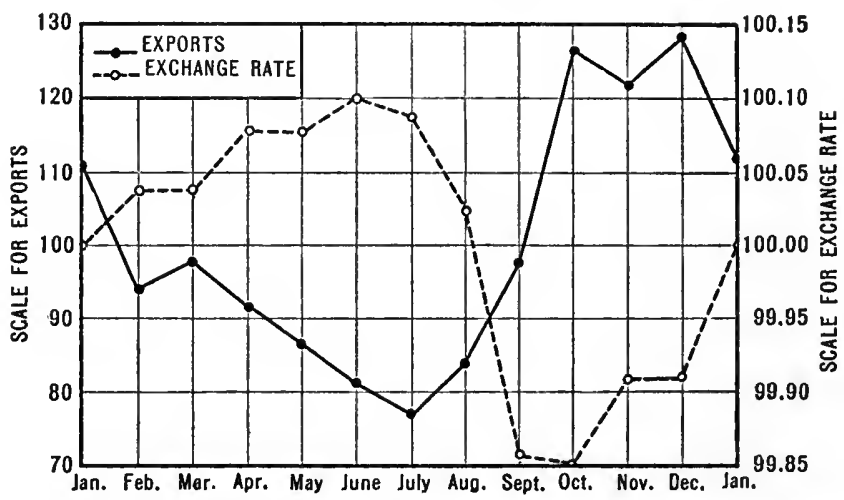

Certain of the conclusions which appear from the investigation, the results of which are embodied in the foregoing chart, are obvious at once. During the thirty years under review, the sterling rate was subject, on the average, to a seasonal increase from January to June. From the high point attained in that month the rate fell sharply to September, slowly receding further to its low point

${ }^{1}$ Bullock, Williams, and Tucker, "The Balance of Trade of the United States," The Review of Economic Statistics, July, 1919, p. 240. 
reached in October, after which it gradually moved upward again. Moreover, there was a remarkably close inverse relation between the seasonal variation of exports and that of the exchange rate, the latter rising and falling as the former diminished and increased.

The foregoing statement of the forces which tend to maintain an equilibrium between international payments is applicable under normal conditions. It cannot, however, explain the situation which has arisen as a result of the war. Thus, in August, 1914, demand sterling was quoted in New York at $\$ 6$, and cables at $\$ 7$ per $£$. Since that time it has fallen as low as $\$ 3.19$. The French franc, with a par value of 19.3 cents, was worth 33 cents in New York in August, 1914, and since that time has fallen to less than 6 cents. The Canadian dollar has had as low a value as 82 cents in the New York market, while the German mark, with a par value of 23.8 cents, has already touched, in its downward course, approximately 1 cent. ${ }^{1}$ These wide variations have resulted from the practical suspension of free gold shipments between countries. The effect has been to remove, for the time, the old limits on the possible variation of the exchange rates. The gold points have ceased to function.

Under normal conditions, as is well known, the limit to exchange fluctuations, in either direction, is determined by the cost of transporting specie. The normal upper limit is par, plus the cost of ${ }^{1}$ In June, 1921. 
shipping gold out of the country, the usual lower limit par, minus the cost of shipping gold into the country. Exchange cannot normally depart farther from par, for the reason that with the rate at the specie point it becomes cheaper to make or receive payment in gold, including the costs incidental to transportation, than by bills of exchange. The total normal fluctuation, therefore, in the exchanges between any two countries is measured by twice the cost of transporting specie. Although, in general, the value of international bills can vary only within these narrow limits set by the gold points, there are certain exceptional temporary deviations from the rule. If a favorable exchange be attended by a stringency in the domestic moneymarket, the rate may fall below the lower specie point. In such a case, the exchange rate, already depressed by the assumed favorable balance of credits over debits, would fall still further, owing to the restricted ability or willingness of money dealers to purchase foreign bills at a time of "tight" money. Thus on December 7, 1903, sight sterling bills fell in New York to so low a point as $\$ 4.8275$, notwithstanding the fact that the normal lower gold shipping point is about $\$ 4.845$. Likewise, there are circumstances under which the exchanges may rise for brief periods above the upper point. Such a condition would arise in the event of heavy imports and the prospect of a large demand for gold shipments out of the country occurring simultaneously with reduced domestic gold 


\section{THEORY OF THE BALANCE OF TRADE 31}

reserves. The rate for sight sterling in New York, for example, rose during 1896 , to $\$ 4.91$ per pound, although the normal upper gold point is but $\$ 4.885$. At that time an important banking syndicate in New York sought to safeguard the gold reserves in the United States Treasury. ${ }^{1}$

Since 1914, however, conditions have not been normal. The "dislocated exchanges" are the outcome, as already intimated, of the cessation of operation of the gold points which, in turn, is the result of deranged trade balances, the drain of gold from Europe, the gold embargoes, and the excessive issues of paper money.

The general effect upon the foreign exchanges of government restrictions upon the export of gold may be revealed by an example. After the entry of the United States into the war, in April, 1917, the American dollar suffered an extraordinary depreciation in certain of the neutral countries, while continuing to stand at a high premium in the belligerent countries. The explanation of the changes in both groups of rates is fundamentally the same, and is to be found chiefly in the gold embargoes. In the belligerenti countries, the dollar went to a premium because the balance of payments due the United States on account of goods purchased in that country was so enormous that the embargoes placed by the European belligerents on the export of gold made their task of meeting the American payments more impossible than ever. On the other ${ }^{1}$ Whitaker, "Foreign Exchange," p. 519. 
hand, the dollar went to a discount in various neutral countries, notably Sweden, the Netherlands, and Argentina, on account of the fact that the United States, while importing heavily from those countries, was unwilling to deplete its gold reserves and for that reason was unwilling to export the gold necessary to restore the unfavorable balances.

It would appear that Goschen's contention, already cited, is peculiarly applicable to the present condition of the exchanges. The fundamental cause of the extreme deviation from par probably lies in the nature of the currencies, particularly of the European countries. Gold has largely disappeared from the channels of trade in Europe and in its stead we find a bewildering array of paper currencies, issued in so large a volume that many of them lack even a semblance of stability of value. It has been estimated by Dr. O. P. Austin that the paper circulation of the fifty principal countries of the world, with a value in July, 1914, of $\$ 7,500,000,000$, had been increased by November, 1920, to a value (on a pre-war or normal basis) of $\$ 81,000,000,000 .{ }^{1}$ In this estimate no account is taken of the vast issues of Bolshevik currency. With the enormous increase in paper issues and the reduction in the production of gold, the ratio of gold to notes has naturally fallen. It was estimated that for the countries in question the ratio declined from 66.8 per cent in July, 1914, to 9.3 per cent in November,

${ }^{1}$ Austin, "World Debts and Paper Currency," The Americas, November, 1920. 
1920. Naturally, in many countries the showing is much less favorable than this average condition. In the case of Austria-Hungary the ratio of gold to notes declined from 54 per cent in 1914 to $4 / 10$ of 1 per cent in November, 1920.

The old or normal parities of exchange were stated in terms of gold, or, with respect to countries not entirely on the gold basis, upon a reasonably fixed and standardized basis of currency. With the present inflation of the currencies the old parities do not apply, and rates are at a discount approximating the discount of the currencies from gold. Under the circumstances the price of foreign exchange is a fairly sensitive indication of the state of depreciation of the paper money. This, of course, does not mean that the ordinary items in the international trade account, such as exports, imports, interest and shipping charges, etc., are to be disregarded. Their influence still is felt, although for the time greatly overshadowed by the disturbing effects of depreciated paper currencies. While exchange rates normally register changes in the currents of international payments, they also, to some extent, and especially during such abnormal periods as the present, register the value of a nation's currency, inasmuch as they present an effective comparison with foreign gold monies. Thus, quite irrespective "of whatever actual business may be going on, no one would be willing to exchange two Canadian dollars, which will buy a bushel of Manitoba wheat, for four 
rubles [approximately the pre-war or normal equivalent of two Canadian dollars], which will not buy a Russian newspaper."

The foreign exchanges, in the presence of depreciated paper money, are accordingly subject to two sets of influences-the normal one, growing out of the settlement of the balance of foreign indebtedness, and the depreciation of the paper currency. Inasmuch as British paper is subject to a depreciation of approximately 20 to 25 per cent (June 1921) while that of the United States has been maintained at its old parity with gold, it follows that a bill of exchange on New York, which represents to the London market the approximate equivalent of gold, would sell in London at a price determined mainly by the price of gold in British paper. However, the relation of imports to exports is not without its influence upon the gold premium. When, under conditions of depreciated paper, the price of foreign exchange falls or rises, in response to trade influences, the premium on gold moves in the same direction owing to the effect of possible gold shipments.

- On the other hand, the depreciation of paper, followed by a depreciation of exchange, has a reciprocal influence upon the course of foreign trade, or the relation of imports to exports. The opinion often maintained that a depreciated paper currency always serves as an incentive to exports and a check on imports is not in accord with facts. For example, the exporter, it is said, of the country 
whose exchange is depreciated, receives payment for his goods in the form of a foreign bill of exchange calling for foreign gold. This he sells to advantage in his own country for a larger quantity of the domestic (depreciated) money.

The case, however, is not so simple. In the country with depreciated paper, the specie premium may be higher or lower than the level of prices. When higher than prices, exports are stimulated, inasmuch as the foreign (gold) bill of exchange yields to the exporter more of his domestic paper money. When the specie premium, however, is lower than the range of prices, it discourages exports and stimulates imports, since the exporter's goods are now worth relatively less abroad than at home and the importer finds it easier to pay for the foreign goods. This influence "depends on the divergence between the gold premium and the real depreciation of the paper, which may be in either direction."

A notable example of this truth may be found in the conditions which prevailed throughout a large part of Europe during the years 1917-20. It appears that the rise of prices, in the local currencies, in those countries did not by any means coincide with the depreciation of the exchanges, or, what was substantially the same thing, the premium on gold. ${ }^{1}$ Instead, the price increase at one

It has already been suggested that the depreciation of the exchange in a country with depreciated paper would indicate substantially the price of gold in the local currency. 
time exceeded the fall in the exchanges, while at another time the reverse was true. And naturally the effect upon exports and imports was not uniform during the two periods. In England, France, and Italy throughout 1917, 1918, and the early part of 1919, exchange on the United States had

The Purchasing Power Parity of the British Pound and the Depreciation from Par Value of the British

Pound in New York Exchaxge

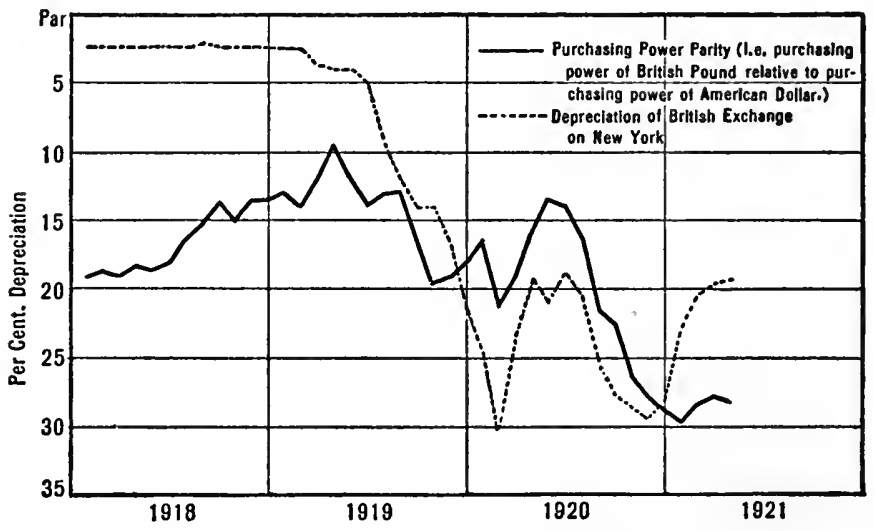

risen less than prices. ${ }^{1}$ Conditions were reversed during the latter part of 1919 and throughout-1920. During the earlier period imports from the United States to these countries were favored. During the later period imports from Europe into the United States were favored. This general reasoning will be made more clear by the diagram which follows. The internal value of the British pound,

${ }^{1}$ The Monthly Review, The Federal Reserve Bank of New York, May, 1921, p. 5. 
THEORY OF THE BALANCE OF TRADE 37

as expressed in its domestic purchasing power, is contrasted with its external value, as revealed in the New York exchange rate. The divergence between the two measures the stimulus to exports or imports as the case may be.

Under normal conditions the two curves would tend to move in the same general direction, though not necessarily together. The wide disparity between the two lines prior to March, 1919, is explained by the fact that British exchange was "pegged," or arbitrarily fixed, from October, 1915, to March, 1919. As a consequence, during that period paper prices in Britain rose faster (i. e., purchasing power of the British currency declined faster) than the controlled exchange rates were permitted to fall.

An equilibrium is reached if, and when, the increase of prices (i. e., the purchasing power of the currency) corresponds with the increase in foreign exchange rates (i. e., the depreciation of the exchange of the country concerned). In this case no artificial stimulus will be felt by either exports or imports. This was doubtless the case in the United Kingdom for a short time during December, 1920, when the two curves coincided at the point of intersection.

Both kinds of divergence or spread are essentially of a temporary character. The spread, in whichever direction it may exist, will set in motion forces that will tend to remove it. If prices, for example, are high in relation to exchange, and if im. 
ports for that reason are stimulated into the country with depreciated paper, this very factor of increased imports will have the effect of reducing the supply of foreign exchange. The price of exchange will, therefore, rise with the result that the exchange premium, already considerable it may be, will be further increased. This will reduce the disparity between prices and the exchange with which we started. Naturally, during periods of excessive inflation and of abnormal foreign trade conditions the "spread" may persist a longer time than would otherwise be the case.

It is evident that in a consideration of foreign exchange and its bearing upon trade, account must be taken of two different elements or influences. One of these is the result of inequalities in international indebtedness. This is the normal one operating at all times. The other, the result of currency inflation, is especially prominent during such abnormal periods as the present. The former operates as a bounty on exports or imports as the case may be, the latter, in the long run, does not. Thus, in the absence of a depreciated currency, a so-called unfavorable exchange which arises as a result of an adverse balance of international payments does serve as a bounty on exports from the country mak. ing the payments. In this instance, by our hypothesis, the currencies of both countries are on the same basis, gold, and there is an unrestricted movement of the means of payments, gold or merchandise. If, however, gold cannot be shipped, either because 
there is none available in the debtor country or because of government restrictions, then the place of the classic gold point, as a limit to the possible movement of the exchanges, is taken by the cost of shipping the next best means of payment. At once the possible variation in the exchange rates becomes greater than at ordinary times. If the currencies of the two countries cease to be on the same basis, if one of them, for example, allows its paper money to suffer depreciation in terms of gold, then it becomes necessary to assume the existence of a new par of exchange which will provide for the existence of this new basis. The resultant exchange premium growing out of inflation will not in the long run constitute a bounty on exports because, as already suggested, prices and production costs will in general increase correspondingly. The bounty, however, which may arise will follow as a result of a less rapid increase in prices than in the exchange premium, the latter responding to changes in the balance of international payments. A depreciated currency will affect both the level of prices and the foreign exchanges. But the exchanges are directly influenced as well by changes in the balance of international payments. ${ }^{1}$

${ }^{2}$ Although the depreciation of exchange due to currency inflation will not, in the long run, operate as a bounty to exports, it may do so before the full effects of inflation have worked themselves out. In this case some prices will have risen and others not, or at least not proportionally. This state of afiairs obviously intensifies exactly that relative difference in costs which is the tap root of all foreign trade, and so may encourage or penalize, 
The effect upon the movement of exports and imports is, therefore, not uniform in all cases. "It is due," we are reminded by Professor Taussig, "to the divergence between general prices on the one hand, and the price of foreign exchange and gold on the other. And during the time for which the divergence lasts-very likely a considerable timeit may run either way, and may stimulate or depress exports. It operates to promote exports from the country which has payments to make." 1 From this statement there emerges, by implication at least, the conclusion that the essential factor influencing exports and imports is not the mere depreciation of the exchanges as such; but, instead, it is the divergence between the exchange rate and the general price level. It would follow, therefore, that a depreciated exchange would not affect the exports or imports of a country after a fairly static condition of stable depreciation had been reached. Thus, if sterling exchange in New York were to stand fairly uniformly for a number of years at

not trade in general but particular lines of export or import. It is suggested that in the pursuit of attractive generalizations this important matter is sometimes overlooked.

Further, if the general rise in prices due to inflation is less than the general increase in the rate of exchange, e.g., as in Germany to-day, then there is obviously a bounty on exports. If the argument just: outlined is correct, then this obvious bounty is the measure of the extent to which the adverse exchange rate of Germany results from an adverse balance of payments (indemnities and the like).

' Taussig, "International Trade under Depreciated Paper," Quarterly Journal of Economics, May, 1917. 
THEORY OF THE BALANCE OF TRADE 41

about $\$ 3.75$, neither the imports nor exports of Great Britain would probably be affected. They would be substantially the same as they would have been had there been no depreciation. However, one essential difference would appear in a higher general level of British prices, measured in the depreciated currency, and higher to the extent of about twenty-five per cent than would have been the case had exchange remained at par. The so-called bounty to the exporter is, therefore, not the result of a mere premium on foreign exchange. Instead, it is the result of a rising premium, moving in advance of the rise in prices, or of a premium, static it may be, greater than the increase in the price level. 


\section{CHAPTER II}

THE BALANCE OF TRADE OF THE UNITED STATES

In applying the principles outlined in the foregoing chapter, attention will be directed alike to countries whose trade balance is marked by an excess of exports and to those whose foreign trade is characterized by an excess of imports. The countries which stand out most prominently in this regard, in their respective groups, are the United States and the United Kingdom. These two, for many years, have been the outstanding examples respectively of exporting and importing countries. Attention will be directed first to the United States, the country par excellence with an excess of merchandise exports over imports.

A notable feature of the American trade balance is the wide disparity between the value of exports and imports. During the three fiscal years, 191113, for example, the excess of merchandise and silver exports over imports had an average annual value of $\$ 597,000,000$. And this characteristic of excessive exports has marked American foreign trade, as already stated, since 1874. It is at once evident that such large and long-continued credit balances due the United States cannot have been 
paid in gold. Recalling the principle that in every country the position toward which international trade always tends is one of equivalence between total credits and total debits, we shall be led to conclude that the American credit balance on account of merchandise must have been offset by an excess of invisible debits over invisible credits. The mer-

$\begin{aligned} \text { Balance of Mrrchandise Trade Expressed as a Percentage } & \text { of Total Merchandise Trade, 1821-1918 } \\ \text { of } & \end{aligned}$ (After 1873 silver is treated as merchandise)

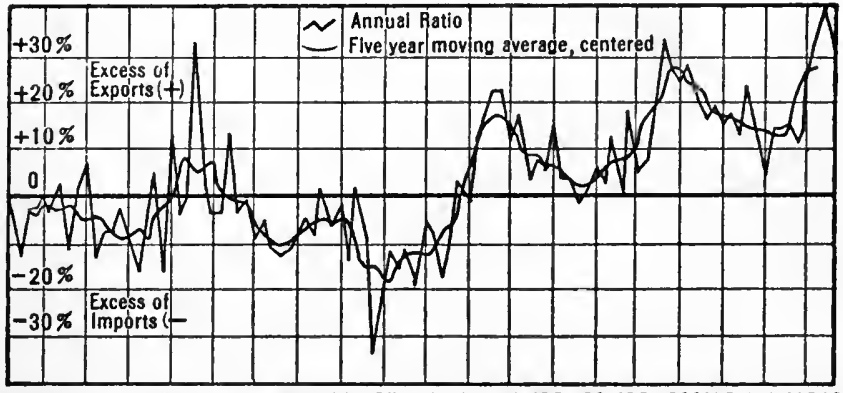

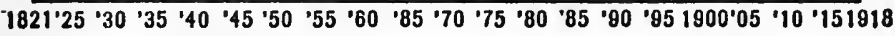

chandise or visible balance of credits must have its roughly equivalent counterpart in a balance of invisible debits.

A survey of the course of American foreign trade during the past century and a quarter will enable us to relate certain features of the trade balance to the varying influence predominatingly exercised from time to time by one invisible factor or an-

${ }^{1}$ Bullock, Williams, and Tucker, "The Balance of Trade of the United States," The Review of Economic Statistics, July, 1919, p. 233. 
other. As indicated in the foregoing chapter, the balance of trade was marked by an excess of imports prior to 1874 . This so-called unfavorable balance prevailed from 1789 onward, except for the period 1838-49. The character of the balance has reflected changes in the various invisible items of indebtedness. The foregoing chart depicts the balance of merchandise trade of the United States from 1821 onwards.

The foreign trade of the United States before 1820 as well was marked by an excess of imports. This is explained by the foreign earnings of the American merchant marine, which at that time was in a flourishing condition. The merchandise trade debit was not only offset in this manner, but it was more than balanced. That this must have been so is evident from the fact that "during most of the period under consideration, London exchange was at a discount in the United States," in spite of the importation of foreign specie and the repayment by the United States of certain foreign loans.' From 1820 onward until the temporary appearance of an export balance in 1838, the continuing and growing excess of imports was fostered, in part, by the willingness of foreigners to invest capital in American enterprises. During these years, however, as in the earlier period, the principal factor in settling the foreign obligations of the country was still the merchant marine earnings. The excess of merchandise imports did not

${ }^{1}$ Bullock, Williams, and Tucker, op. cit., p. 217. 
occasion an outflow of specie, but, on the contrary, notwithstanding the fact that, at the time, there was little mining of the precious metals in the United States, the amount of specie in the country actually increased. This seeming paradox finds its explanation in the statement above that the merchant marine earnings were supplemented by investments of foreign capital within the country. Among the results was a vigorous speculative movement marked by rapidly increasing immigration, inflation of currency, rising prices, and land speculation.

This movement culminated in the crisis of 1837 which was followed by several years of depression. The recovery, appearing about 1844 , was accelerated by the large increase in exports of foodstuffs, occasioned by the potato famine in Ireland and other crop failures in Europe. So sudden and large, however, was the resultant excess of exports that a net importation of specie amounting to $\$ 22,000,000$ took place in 1847 . This in turn so affected the situation that in the following year an excess of imports reappeared, accompanied by a net export of nearly $\$ 10,000,000$ of specie.

During this period of twelve years following the panic of 1837, the discrepancy between imports and exports appeared to be settled principally through shipments of specie. Services and securities seemingly played but a small part. In this respect the period in question stands out in contrast to "all previous and subsequent periods in 
the history of our [American] foreign trade." 1 This distinction was the outcome partly of the difficulty, for the time, of borrowing abroad, and partly of improved facilities for export, due to the improvement of Western lines of communication.

Owing to the panic of 1837 and the repudiation of debts by several of the states, European investors suffered, and naturally became apprehensive of the United States as a field for investment. During the years immediately following, while their confidence was being slowly reëstablished, the much restricted supply of foreign capital available to the United States had the effect of reducing the ability of that country to buy foreign goods. The excess of merchandise exports was roughly balanced by an excess of specie imports. And merchant marine earnings, which formerly had had the effect of swelling the volume of imports, now served to offset certain invisible debits against the country, the principal one being interest on foreign capital.

Following its recovery from the panic of 1837, the country soon witnessed a return of the "unfavorable" trade balance. The period of twentyfour years which opened with the gold discovery in California and closed with the panic of 1873, was

${ }^{1}$ Bullock, Williams, and Tucker, op. cit., p. 220. The writer wishes to acknowledge his indebtedness in the preparation of this chapter to the authors of this scholarly and authoritative article. Because of this general acknowledgment, footnote references to the article will appear less frequently than otherwise would be the case. 
characterized, as may be noted from the chart above, by an unusually large excess of imports; an excess which, in the main, quite regularly increased till the very last years of the period. Within this span of years there occurred the Civil War, with its hampering effect upon the export trade, the decline of the American merchant marine as an important credit factor, a large expansion in the production of gold, and the remarkable increase in the quantity of foreign capital borrowed for domestic investment.

Each of these factors contributed toward the result. The Civil War was responsible for the fact that during the five-year period, 1861-65, the value of American exports amounted to but sixty-four per cent of the value of exports during the preceding five years and fifty-two per cent for the five years following. The principal reason for this decrease lies in the war-induced interruption of the export trade in cotton. After the war, exports increased, although not so rapidly relatively as imports. Imports as well were affected as a result of the war, in perhaps a less direct, but none the less real, manner. So much so, that the remarkable expansion in the import trade during the eight years following the war gave to them the distinction of being one of the great "boom" periods in American history.

As a consequence of the financial policy of the war, specie payments were suspended in 1861 , and in the following year the Government began its 
issues of inconvertible paper money. Accompanying the extravagant issue of this inconvertible currency, we find heavy expenditures on military account and an unavoidable destruction of economic goods. The result naturally was a violent rise in prices, which fostered and intensified the speculative movement. In so far as prices were raised by the mere depreciation of paper, no stimulus would be felt by imports, for foreigners were, of course, not paid for their goods in paper values. However, it is certain that the spirit of speculation and extravagance, both public and private, increased gold prices above the foreign level with the result that the importation of goods was stimulated.

Moreover, the level of gold prices was affected more directly by the increase in the domestic gold output following the opening of the mines in California. As a result of the stimulus imparted to the import trade through increased prices, it soon became necessary to export gold as an offsetting factor. With the depreciation of the paper currency this outflow of gold was increased. We find in The Review of Economic Statistics that for the entire period, 1850-73, the net outflow of specie, of which silver formed but a small element, amounted to $\$ 1,098,200,000$, or an annual average of $\$ 45$,800,000 . For the same period the excess of merchandise imports over exports amounted to $\$ 1,541,000,000$. Combining the two, we find the net 


\section{BALANCE OF TRADE OF UNITED STATES 49}

balance against the United States of both merchandise and specie to be $\$ 443,000,000$, or an annual average of $\$ 18,400,000$.

Against this visible debit balance is to be set the balance of invisible items, of which the chief were foreign borrowings, interest payments, ship earnings and freight charges, tourist expenditures, and the capital holdings of immigrants.

The passing of the American merchant marine was contemporaneous with the Civil War. The substitution of the steel steam ship for the sailing ship and the change in the subsidy policy of the United States were other factors in the decline of American ocean shipping. With the virtual disappearance of the merchant marine, the old profits on shipping, so long an important agency in maintaining the equilibrium of foreign payments, gradually vanished. In time, they ceased to be a credit item and their place was taken by a debit charge in the form of freights paid to foreign shipping companies. For the period in hand, however, the freights earned by American ships surpassed the charges paid to foreigners by a small amount.

A factor of prime importance whose existence made possible, in great part, the large excess of merchandise imports during this period, was the very large quantity of foreign capital invested within the country. These years, as already stated, were marked by speculative activity. One phase of this appears in the rapid expansion of the rail- 
way mileage. Railroads were built on a scale to that time undreamed of-built far beyond the immediate demands of trade or population. This activity was furthered by a large inflow of foreign capital. The extension of the railways stimulated a movement of population westward, which in turn served as an impetus to commercial and industrial activity. The interest of the European investor in the United States had been abundantly restored. For the period as a whole probably $\$ 1,000,000,000$ of foreign capital was invested in the United States. There must be charged, however, against this sum the annual payments of interest to foreigners. These have been estimated in the aggregate at about $\$ 900,000,000$. These two items taken together yielded, therefore, a net credit, although, it is true, a comparatively small one. The other and lesser invisible items are estimated roughly to have balanced. The net result for the period, 1850-73, taking into consideration all factors, both visible and invisible, was a slight debit balance against the country.

Evidence was already at hand, even before the close of the period, that an overturn must soon occur in the merchandise balance. It was forecast by David A. Wells in 1869 that commodity exports must increase and surpass imports, in order that interest payable to European capital lenders be paid. The annual interest charge had grown so large that sooner or later the merchandise balance must show an excess of exports to offset the grow- 
ing invisible items. With singular prophetic accuracy Professor Cairnes wrote, in 1873: ${ }^{1}$

"These considerations lead me to the conclusion that the present condition of the external trade of the United States is essentially abnormal and temporary. If that country is to continue to discharge her liabilities to foreigners, the relation, which at present obtains between exports and imports in her external trade, must be inverted. Her exports must once again, as previous to 1860 , be made to exceed her imports, and this by an amount greater than the excess of that former time in proportion as her financial obligations to foreign countries have in the interval increased. This, it seems to me, is a result which may be predicted with the utmost confidence. The end may be reached either by an extension of exportation, or by a curtailment of importation, or by combining both these processes, but by one means or other reached it will need to be."

Before the end anticipated by Cairnes could be attained, however, it was essential, as indeed he pointed out, that a readjustment of prices intervene. An enabling condition making possible an excess of exports over imports was the substantial reduction in prices in the United States relative to Europe. The decline in the price level in that country, sufficient to make importation more diffcult and exportation more profitable, would probably come, he thought, "with a crash." He, there-

${ }^{1}$ Cairnes, "Some Leading Principles of Political Economy," p. 444. 
fore, viewed "the immediate future of American trade as a period of much disturbance and fluctuation, culminating, it is possible, from time to time, in commercial crises."

His predictions were both speedily and literally fulfilled. Beginning in Vienna in the spring of the year and passing through Germany and England, the crisis of 1873 made its appearance in New York in September. It affected practically every commercial and financial operation of the country, and the succeeding depression, notable both for its severity and duration, continued in most lines of industry until 1878. Europe, the ready source of capital, was now, for the time, dried up. Railroad and other construction enterprises ceased. With the pricking of the speculative bubble, and the attendant contraction of credit and severe curtailment of business activity, prices declined. At once imports were restricted and exports increased, with the result that the excess of merchandise imports which amounted in 1873 to $\$ 120,000,000$ was changed in the following year to an excess of exports equal to $\$ 19,000,000$. And from 1874 to the present time American trade has been marked by an export balance except in the four years, 1875, 1888,1889 , and 1893. The early seventies formed a transitional period in the country's foreign trade, the stage at which it became a so-called "mature" borrowing country.

The recovery from the period of depression was accelerated by the synchronization in 1879 of har- 
vest failures in Europe and bountiful crops in the United States. An unusually large inflow of gold into the country was occasioned by the heavy exports of agricultural products which followed. And the resumption of specie payments, as well, in 1879 , which was rendered more easy by these large gold imports, had the effect of restoring soundness to the monetary and credit system.

A period of prosperity was thus ushered in, marked by another era of rapid railroad construction and general industrial expansion. This in turn served to attract large quantities of foreign capital. The prosperity was short-lived, however. Crop failures and excessive railroad construction led to the minor crisis of 1884 . During the adverse years there was a considerable withdrawal of capital by European investors. The depression in turn was of short duration, the year 1886 again witnessing renewed extension of railways. Once again foreign capital, chiefly British, sought investment in the United States. That country, in common with Argentina, Germany, and others, profited from the readiness with which English capitalists were willing to invest abroad their large accumulations of capital. This "wave of British investments" continued until severely checked by the Baring panic of 1890, in London, occasioned largely by the inability of the Argentine Government to meet payments of interest. The effects of this European crisis were felt acutely in the United States, although a complete breakdown was de- 
ferred until 1893, owing to the enormous crops and heavy exports of 1892 .

As a consequence of the critical situation in England, following upon the failure of Baring Brothers, a heavy demand for funds was made upon the New York money market. British holders of American securities sold extensively in New York, thus inducing large gold exports. A result of this reverse security movement against the United States was the withdrawal of about $\$ 300,000,000$ of European capital during the years 1890-96. Although "sterling exchange in New York stood al-" most continuously at the gold export point" during the first six months of 1891, the crisis in the United States was avoided, as stated above, till 1893.

During the twenty years intervening between the major crises of 1873 and 1893 the excess of exports over imports had an average annual value of about $\$ 113,000,000$. In the same period there was a net export of gold averaging $\$ 5,000,000$ a year. This favorable balance on account of gold and merchandise was the offsetting factor, balancing the large volume of "invisible" debit items against the country. While approximately $\$ 1,000,000,000$ of new foreign capital was invested in the United States during the two decades in question, the amount of interest payable abroad had naturally increased proportionately with the steadily accumulating volume of foreign borrowings, with the result that the total interest payments during these years probably amounted to $\$ 1,870,000,000$. The net result, 
therefore, taking both factors into account, was a debit of $\$ 870,000,000$, or an annual average of about $\$ 40,000,000$. The decline of the merchant marine had continued, and to such a degree that the freight charges payable by Americans to foreign shipping companies exceeded the freight earnings of American ships engaged in foreign trade, by an amount which averaged for the period about $\$ 25,000,000$ a year. A further invisible debit item was the expenditure of American travelers abroad. It is estimated that this charge exceeded the expenditures of European tourists in the United States by approximately $\$ 35,000,000$ annually. And, finally, it is necessary to take account of immigrant remittances and other miscellaneous charges against the country. Although the volume of remittances by immigrants was not nearly as large as it became after the opening of the new century, it was none the less of considerable importance. In the study presented in The Review of Economic Statistics an average annual sum of $\$ 20,000,000$ is allowed to cover this and other lesser items of indebtedness. During the years between the two panics, therefore, the visible credit balance on account of merchandise and gold approximately equaled the excess of invisible debit items.

From that time onward till the outbreak of the World War the balance of international payments was similar, in its essential features, to that of the period just considered. It is true, the favorable merchandise balance was much larger. During the 
twenty year's preceding the war the excess of exports averaged annually about $\$ 485,000,000$, whereas, as mentioned above, the yearly average for the two decades before 1894 was $\$ 113,000,000$ only.

Before turning to a consideration of the invisible factors which served to make this excess of exports imperative, it will be well to take note of the general condition of business in the country at the time. In common with the rest of the commercial world, the United States entered upon a period of rapid expansion during the late nineties. With but minor reactions, this condition of prosperity continued till 1907.

The low-water mark of the depression which followed the panic of 1893 was reached in the United States in 1895. The lowest point in the general downward movement of prices which began in the panic of 1873 was touched in 1897. Market conditions at home were adverse, stocks and materials had accumulated, and wages were low. Conditions in general were very depressed, but, for this very reason, the country was in a position to take instant advantage of export opportunities in foreign markets. Not only were agricultural products exported in large quantities, but manufactured goods began to flow abroad in increasing volume. American manufactures invaded even the markets of continental Europe. Manufactured products constituted 18 per cent of the total exports in 1892, 25 per cent in 1895,35 per cent in 1900 , and nearly 49 per cent in 1913. 
So notable was the expansion in exports that the balance of international payments during the twenty years prior to the war was marked by a net import of gold, averaging $\$ 9,000,000$ annually. In other words, the exports were sufficiently large to equal both the imports and the balance of invisible debits and still leave a credit which was met by a gold inflow. It is not to be concluded, however, that each year of the period was marked by a net import of specie. Indeed, there were nearly as many years in which the specie movement was outward as those marked by an inflow.

It has already been stated that the merchandise balance during these years was characterized by an excess of exports averaging $\$ 485,000,000$. If now we deduct from this amount the $\$ 9,000,000$, constituting the net gold inflow, we shall have an annual average of $\$ 476,000,000$ as a net credit balance on account of merchandise and specie. As an offset to this sum we shall expect to charge an approximately equal debit balance on account of the several invisible items.

The principal factors in this so-called invisible account were new capital borrowings from abroad and interest payments on American capital invested abroad, on the credit side; while on the debit side the chief items were the annual interest charges payable abroad, tourist expenditures, immigrant remittances, and ocean freight charges. These items may be set forth with approximate accuracy. The new foreign capital borrowings ex- 
ceeded the volume of American capital invested abroad by an annual average of about $\$ 50,000,000$. The larger items, however, we shall find on the debit side. Net interest charges payable abroad averaged $\$ 160,000,000$, tourist expenditures, $\$ 170$,000,000 , immigrant remittances, $\$ 150,000,000$, net freight charges, $\$ 30,000,000$, and certain miscellaneous items, including insurance premiums, $\$ 30$,000,000 . If we were to assemble all the factors, both visible and invisible, we should discover for the twenty years in question a comparatively small net debit against the country.

In order the more concretely to reveal the state of the American balance of international payments, let us construct the trade balance sheet for the United States for the three fiscal years 1911-13. It naturally will vary somewhat from the balance struck for the year 1909 by Sir George Paish.

Turning first to the visible trade items let us consider the balance of trade on account of merchan. dise and specie. For the three fiscal years in question the statement is as follows:

Exports and Imports of Mirrchandise, Silver and Gold, $1811-13^{1}$

In Millions

\begin{tabular}{c|c|c|c}
\hline Merchandise & 1911 & 1912 & 1913 \\
\hline Total Exports . & $\$ 2,049.3$ & $\$ 2,204.3$ & $\$ 2,465.8$ \\
Total Imports . & $1,527.2$ & $1,653.2$ & $1,813.0$ \\
\cline { 3 - 4 } Excess of Exports & $\$ 522.1$ & $\$ 551.1$ & $\$ 652.8$ \\
\hline
\end{tabular}

Average annual value of excess of exports, $\$ 575,300,000$

1 "Statistical Abstract of the United States, 1913," pp. 327, 639. 
BALANCE OF TRADE OF UNITED STATES 59 In Millions

\begin{tabular}{|c|c|c|c|}
\hline Silver & 1911 & 1912 & 1913 \\
\hline $\begin{array}{l}\text { Exports } \\
\text { Imports }\end{array}$ & $\begin{array}{r}\$ 64.7 \\
45.9\end{array}$ & $\begin{array}{r}\$ 64.9 \\
47.1\end{array}$ & $\begin{array}{r}\$ 71.6 \\
41.3\end{array}$ \\
\hline Excess of Exports & $\$ 18.8$ & $\$ 17.8$ & $\$ 30.3$ \\
\hline
\end{tabular}

Average annual value of excess of exports $\$ 22,300,000$

In Millions

\begin{tabular}{c|c|c|c}
\hline Gold & 1911 & 1912 & 1913 \\
\hline Exports $\ldots \ldots$ & $\$ 22.5$ & $\$ 57.3$ & $\$ 77.8$ \\
Imports $\ldots \ldots$ & 73.6 & 48.9 & 69.2 \\
${ } }$ & $\$ 51.1$ & $\$ 8.4$ (exp.) & $\$ 8.6$ (exp.) \\
\hline
\end{tabular}

Average annual value of excess of imports $\$ 11,400,000$

On account of merchandise and specie, therefore, there was a total average yearly excess of exports over imports of $\$ 586,200,000$.

This large credit balance served, we may anticipate, as the offset against a debit balance on account of the invisible items. Chief among the invisible factors were capital investments and interest payments. The importation of capital into the United States from Europe dates from the seventeenth century. The purpose at that time was the development of sugar, tobacco, and cotton plantations and the extension of mercantile undertakings. Later, large amounts of foreign capital were invested in American government securities. Still later, the chief American borrowers were the railroads. It was estimated by Sir George Paish 
in 1910 that approximately $\$ 6,000,000,000$ worth of foreign capital was then invested in the United States in some form of permanent securities. ${ }^{1}$ of this about $\$ 3,500,000,000$ was British capital, $\$ 750$,000,000 German, the same amount Dutch, and $\$ 500,000,000 \mathrm{French}$. Other competent investigators have placed the total of foreign investments in the United States prior to the war at about $\$ 5,000$, 000,000 . If, therefore, the figure $\$ 5,500,000,000$ be taken as approximating the total it will probably be subject to but a small margin of error. The interest charge upon these investments of foreign capital amounted roughly to $\$ 275,000,000$ a year during the three-year period in question. As an offset, however, against this debit there must be placed the interest received by Americans on their capital invested in Canada, Mexico, Cuba, and other foreign countries. United States capital thus invested amounted in 1913 to about $\$ 1,500,000,000$ upon which the interest return was probably not less than $\$ 75,000,000$. Deducting this from the interest payments that the United States had to make to foreign lenders, it will be seen that, during the years immediately prior to the war, the American people were subject to a net payment of about $\$ 200,000,000$ a year to other countries for interest and dividends upon capital. It may be well to point out that the discrepancy between this amount and the item of $\$ 160,000,000$ set forth above as the

${ }^{1}$ Paish, "Trade Balance of the United States," U. S. Monetary Commission Reports, p. 175. 


\section{BALANCE OF TRADE OF UNITED STATES 61}

arerage interest charge on foreign capital during the twenty years preceding the war is an apparent one only and not real. Obviously during the earlier years of that longer period the interest charge was less than during the later years, owing to the fact that the volume of foreign capital invested within the United States was steadily mounting throughout the period.

Against this debit on account of interest payments, however, there is to be placed a credit item representing a net inflow of new capital. Although American capital began about 1900 to flow abroad in large volume for investment purposes it is nevertheless probably true that during the years under review there was a sufficiently large importation of foreign capital to yield a net movement into the country. It is estimated in The Review of Economic Statistics that during the twenty years preceding the war the net inflow of capital amounted to about $\$ 50,000,000$ a year. Inasmuch as foreign capital entered the country in large quantities during the earlier part of the period, while American capital on the other hand sought investment in foreign lands increasingly during the latter part, we may estimate for the years 1911-13 a net inflow of about $\$ 20,000,000$ annually.

An invisible debit nearly as large, for the years under consideration, as that of interest payments was the expenditures abroad of American tourists. Among the consequences which followed in the wake of the wave of prosperity ushered in during 
the last years of the nineteenth century was a large increase in the number of Americans traveling abroad. Thus, the number of citizens of the United States returning to their native country from foreign lands increased from 94,000 in 1898 to 167,000 in 1905 , and 286,000 in 1913. According to the estimate of Paish, American tourists expended abroad about $\$ 200,000,000$ in 1908 . This sum did not include expenditures for clothing, works of art, jewelry, etc., which are declared at the customs and are therefore included among the imports. Against this debit, Paish placed as a credit the expenditure in the United States of foreign tourists, amounting, he estimated, to $\$ 30,000,000$. For the year 1908, therefore, there was a net balance against the United States of $\$ 170,000,000$ on this account. A Bradstreet's computation in 1914 placed the net annual outgo at $\$ 175,000,000 .^{1}$ Their basis of estimate was such that this amount may fairly be looked upon as quite conservative. The average annual debit on account of tourist expenditures for the years 1911-13 may therefore probably be placed quite safely at $\$ 175,000,000$.

A no less notable increase appeared during the first decade and a half of the new century in the growth of immigrants' remittances. As a result of a careful investigation undertaken in 1907 of individual foreign payments by postal orders, by bank drafts, and other means, it was estimated that approximately $\$ 250,000,000$ was remitted to Eu-

${ }^{1}$ Bradstreet's, November 21, 1914, p. 754. 


\section{BALANCE OF TRADE OF UNITED STATES 63}

rope. ${ }^{1}$ It is probable, however, that this sum was too large as a statement of immigrant remittances alone, for the reason that it included certain payments sent abroad in purchase of goods which naturally would appear in the merchandise imports. Allowing for this and other such factors, it is probable that immigrant remittances averaged during 1911-13 about $\$ 175,000,000$ a year.

Among the remaining items of indebtedness the principal ones were freight payments and insurance premiums and commissions to financial institutions. The excess of freight charges payable abroad over freight earnings of American ships in ocean traffic probably averaged about $\$ 35,000,000$ during the period 1911-13. Various miscellaneous items, including insurance premiums and the like, have been estimated to equal about $\$ 30,000,000$ a year during the same period.

Let us now gather together the various items, both visible and invisible, in the form of a balance sheet, based on average annual figures for the years under review.

(Figures denote millions)

Visible Credits Years, 1911-13 Visible Debits

\begin{tabular}{|c|c|}
\hline $\begin{array}{l}\text { Merchandise: average ex- } \\
\text { cess of exports } \ldots \ldots \ldots . \$ 575.3 \\
\text { Silver: average excess of } \\
\text { exports } \ldots \ldots \ldots \ldots \ldots \ldots\end{array}$ & $\begin{array}{l}\text { Gold: average excess of } \\
\text { imports } \ldots \ldots \ldots \cdots \cdots \cdots 11.4\end{array}$ \\
\hline
\end{tabular}

$\$ 597.6$

11.4

Average annual excess of Visible Credits......\$586.2

${ }^{1}$ Speare, North American Review, January, 1908. 
Invisible Credits

Net capital borrowings
from abroad: annual
average $\ldots \ldots \ldots \ldots \ldots$
Invisible Debits

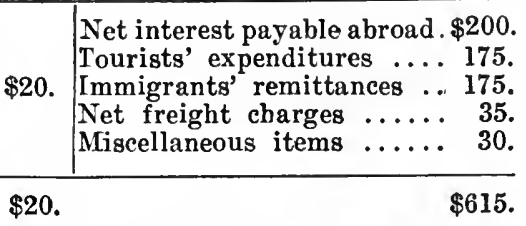

Average annual excess of Invisible Debits......\$595.

Evidence of an inductive character has thus been drawn from the experience of the United States to support the contention, reached deductively in the first instance, that there must be an approximate equivalence for every country between total credits and total debits.

The American balance of trade, with its increasing excess of merchandise exports from 1874 onward, is no more to be considered immune from change now than during the early seventies. The transition which occurred in 1874 in the trade balance from an excess of imports to one of exports is to be followed in the not remote future by a further transition, this time in the opposite direction. Although this change, quite apart from the World War, might have been considered as inevitable sometime in the future, its comparative proximity is the outcome of circumstances growing out of that event.

With the outbreak of war, international trade became utterly dislocated. An extraordinary demand arose in Europe for war munitions and supplies of all kinds, of which the principal source was the 
United States, while at the same time Europe suffered through inability to export goods in return. The result was an unprecedented growth of the export balance of the United States attended by an enormous inflow of gold. Unable to export goods in a volume at all commensurate with their vast purchases of war supplies from the United States and recognizing the rapidly dwindling nature of their gold reserves, the European nations were forced to turn to the United States for loans with which to finance this one-sided trade. On so vast a scale did this occur that the United States, the world's greatest borrower of capital before 1914, became the world's most rapid lender of capital. A further consequence of the war, with an important bearing upon the future balance of trade of the country, is to be found in the merchant marine, which, for so long a time nearly moribund, has been revived on a very large scale.

During the period of the war, from the summer of 1914 to December, 1918, the excess of American exports of merchandise and silver over imports reached the enormous total of $\$ 11,800,000,000$. This represented an average annual excess of exports of $\$ 2,624,000,000$, as compared with the average export balance of less than $\$ 600,000,000$ during the years immediately preceding 1914 . And even that extraordinary total was surpassed by the excess of exports over imports attained during the fiscal year ending June 30, 1919. The export balance of that year, the largest in the history of the country, 
equaled $\$ 4,136,000,000$. During the following fiscal year, owing to the rapid advance in the value of imports, the so-called favorable balance declined to $\$ 2,872,000,000$. That the peak in the American excess of exports over imports has probably been passed may be inferred from the further evidence that during the next succeeding fiscal year, which is to close on June 30,1921 , the export balance will, it is estimated, also fall short of the $\$ 3,000,000,000$ mark.

In addition to the war-induced demand on the part of Europe for American goods, to which reference has already been made, there is a further reason for these abnormally large "favorable" balances. The rise in prices the world over, itself an outcome of the war, has contributed toward the result. Although the quantities of goods exported and imported by the United States were, it is true, larger in 1920 than in 1914, the quantity increase was not at all comparable to the recorded increase in values. Moreover, it is to be noted that American imports since 1914 have, in major part, been drawn from countries not directly affected by the war, and they have consisted largely of commodities not necessary for military purposes. On the other hand, American exports have mostly been goods urgently needed, in the first instance to carry on the war and latterly to feed the starving millions of Europe and to assist in the industrial rehabilitation of that continent. As a consequence, the rise in prices of the goods exported by the United States 
has been, in the main, much greater than the rise in prices of the articles imported.

The decline, during the past two years, in the excess of exports has been the result of a greater relative advance in the value of imports. This decline in the export balance "may be hailed," Professor Litman declares, "as one of the most satisfactory developments in our commercial relations with foreign countries; only through such a decline, if it is carried far enough, shall we, as a creditor nation, be able to place our foreign commercial intercourse on a sound business basis." 1

The large credits accumulated abroad by the United States as a result of the trade balances have been paid, or are in process of being paid, in various ways. Payment of the enormous American balances in goods has been entirely out of the question, owing to the dislocation of European industries consequent upon the war. Likewise, payment in gold or in services has been impossible on so large a scale. While goods, services, and gold have served in part to meet the case, payment has, through necessity, taken other form. Settlement has been effected largely in the form of American loans abroad and the return to the United States of domestic securities held abroad before 1914 .

Owing to the war, the international movement of gold surpassed during the four years and a half from July, 1914, to December, 1918, anything of

${ }^{1}$ Litman, Annals of American Academy, March, 1921. 
the kind known before. While both imports and exports of gold were larger than ever before to and from the United States, there was a net import of gold of $\$ 1,029,000,000$ into the country during the war period. Although, as a gold movement, this was of unprecedented proportions, it nevertheless was comparatively ineffective as an offsetting factor to place against the huge export trade balance of $\$ 11,800,000,000$ accumulated during the same four years and a half. Between December, 1918, and April, 1921, the exports of gold nearly equaled the imports. Gold shipments have, therefore, been but a minor factor in the settlement of the American export trade.

The most important device employed in the financing of this trade and in the regulation of the exchanges has been, as stated above, the transfer of credits. This was effected in three ways: the return of American securities from Europe to the United States, the investment of American capital in foreign countries on private account, and loans by the United States Government to the Allied Governments.

As early as the spring of 1914 the reverse movement in securities began to be noticeable. This early re-sale of American securities back to the United States was chiefly on the part of the continental countries of Europe, and it has been viewed as evidence that war was anticipated by the Central Powers. The selling, which became general with the outbreak of war, continued on so large a 
scale that by December, 1918, no less than approximately $\$ 2,000,000,000$ worth of American securities held abroad in 1914 had been returned. The second method by which American capital was exported was the flotation of foreign loans in the United States on private account. A very large part of the total of capital thus advanced consisted of loans for war purposes. The balance comprised provincial and municipal loans, largely Canadian, and railroad, industrial, and public utility loans, also chiefly Canadian. During the war period of four and a half years, about $\$ 1,520,000,000$ of American capital was exported in this fashion.

The principal method, however, by which the transfer of credits was effected was the third. Subsequent to the entry of the United States into the war in April, 1917, American lending to the outside world chiefly took the form of direct loans to the Allied nations by the United States Government. Under the authority of the legislation which provided for the establishment of credits in favor of the Allied Governments, the United States made direct advances amounting to $\$ 7,319,500,000$ prior to December, 1918.

We may now summarize the foregoing statement of the manner in which American trade was financed during the war period. The enormous excess of exports, amounting, as stated above, to $\$ 11$, $800,000,000$, was settled, in major part, by the export of American capital and, in a lesser degree, by the import of gold. These offsetting factors in 
the aggregate approximated the export total, as evident from the following:

Net importation of gold $\ldots \ldots \ldots \ldots \ldots \ldots \ldots$

Securities returned from Europe ............ $\$ 1,029,000,000$

Private foreign bond issues .............. $1,520,000,000$

Advances by the United States Government in

favor of the Allied Governments ............

$7,319,500,000$

$\$ 11,868,500,000$

There were various minor factors remaining which cannot be disregarded. The shipping situation which arose as a result of the war led to the revival of the American merchant marine in the foreign trade. This is reflected in the fact that for the period under review freight payments receivable by American ships almost equaled the freight charges payable to foreign shipping companies. That this shipping account did not show a net credit in favor of the country is to be attributed to the fact that the merchant marine did not attain its largest proportions till the latter part of the war period. There was, however, a considerable debit charge of another kind against the United States on account of shipping. It is estimated that during the war period the country made payments for foreign shipping chartered to the United States to the extent of $\$ 261,000,000$. Although during the war years tourist expenditures were negligible, it is estimated that immigrant remittances suffered little if any reduction. A further item of some importance is that of interest payments. In view of the extraordinarily rapid export of American cap- 
ital during the war and the accompanying withdrawal of foreign capital from the United States, it was quite to be expected that the interest on American capital abroad should surpass the interest charges on foreign capital invested in that country. This credit item arising from the excess of interest payments receivable was nearly large enough to offset the debits on account of shipping charges and immigrant remittances. In the final balance for the war years, if account be taken of total credits and debits, including both the trade and invisible items, there appears a net debit balance of about $\$ 437,000,000$. "This amount is probably represented by the increase of cash balances of foreign banks in the United States, which are known to have grown notably during the war, by credits advanced and not used within the period, by merchandise paid for and not exported within the period, and other items of similar nature." 1

The essential features of the balance of international payments of the United States since the time of the Armistice may be briefly set forth. The merchandise and silver trade balance has been marked by a continued excess of exports, although, as stated elsewhere, on a declining scale. The United States Government made further direct credit advances in favor of foreign governments amounting to approximately $\$ 2,300,000,000$. The total loaned in this manner by the American Government subsequent to April, 1917, amounts, there-

'Bullock, Williams, and Tucker, op. cit., p. 252. 
fore, to nearly $\$ 10,000,000,000$. With the reduction in and final cessation of such governmental advances, recourse was again had to private capital.

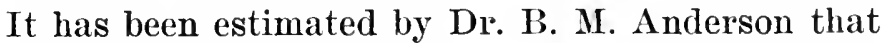
between January 1, 1919, and September 15, 1920, private advances and credits to the amount of $\$ 3,500,000,000$ were accumulated against Europe. ${ }^{1}$ In addition, there have been loans and investments in Canada, in South America, and elsewhere. And finally, in this connection it is necessary to note that there have been large accumulations of unpaid interest upon American capital loaned to European countries. Moreover, as a result of the expansion of the American merchant marine, the item of freight payments has perhaps passed out of the debit column. In any event, whether or not it becomes in the future a large credit item, it is certain that for a time at least the balance either way will not be relatively large. Although the expenditures of American tourists abroad are much reduced for the present, they will doubtless surpass within a few years the pre-war level. Immigrant remittances are probably much larger than before.

Returning now to the assertion, which has already been made, that in the future the American balance of trade must undergo a further transition, to be marked thereafter by an excess of imports, let us note the conditions which support the opinion. The appearance of this anticipated transi-

${ }^{1}$ Anderson, The Chase Economic Bulletin, October 5, 1920. 
tion has been hastened, it was contended, by circumstances growing out of the war. In the face of the unprecedentedly large export balances which have marked American foreign trade since 1915, there is an apparent paradox in the suggestion that the very conditions which brought about this remarkable export situation must hasten the eventual transition to a trade balance marked by an excess of imports.

The notable feature of the pre-war balance of trade was an excess of exports, averaging \$597,600,000 a year, during 1911-13, exclusive of gold shipments. This served, as already stated, as an offset against the debit balance on account of invisible items. The outstanding characteristic of the trade balance during the war years was the astonishing magnitude of the excess of exports, averaging $\$ 2,600,000,000$ a year. Even for a country accustomed to large export balances it was extraordinary. It was balanced, as we have seen, principally by the export of American capital.

If the export of capital from the United States were to continue to be sufficiently large to maintain the equation of indebtedness, then the export balance might be expected to escape substantial reduction. But as we have already noted, in the foregoing chapter, no nation can continue indefinitely to discharge its foreign obligations and meet the annual payments accruing against it by incurring new debts. In time the annual interest charges must exceed the new capital that may be borrowed 
annually. This is true of the European nations as borrowers. It is also true, on its reverse side, of the United States as a lending country. The excess of American exports cannot be viewed as a continuing phenomenon unless there be a large compensating or offsetting debit factor in the form of exports of capital. This is so, obviously, because the United States, now a creditor nation, is the recipient, nominally at least for the immediate present, of enormous interest payments from abroad. Sooner or later, the European countries must cease buying goods on credit and must pay interest on their foreign debts, and to do this they will be obliged to reduce their imports and increase their exports.

With the gradual return to a normal basis of trade, the adjustment of the American trade balance to the new set of conditions will be secured. Already the movement toward normal conditions has begun. The United States Government, under formal pronouncement in January, 1920, has discontinued the practice of direct advances of the Government to finance European countries or to finance exports to Europe. While not involving the cessation of American assistance to Europe, it does mean the substitution of private for public financing of exports. Moreover, the unpegging of the exchanges and the lifting of the American embargo on gold in 1919 were steps in the movement toward normal conditions. With the removal of the other obstructing, or abnormal, factors the anticipated 


\section{BALANCE OF TRADE OF UNITED STATES 75}

readjustment in the trade balance will be hastened. The present situation, so far as the American balance is concerned, may be briefly summarized.

The total of foreign capital invested in the United States has been estimated, it will be recalled, at about $\$ 5,500,000,000$ in 1914 , while the amount of American capital invested abroad equaled about $\$ 1,500,000,000$ at the same time. As a consequence, the United States was then a net debtor country to the extent of about $\$ 4,000,000,000$ and on that account it was subject to a net interest charge of about $\$ 200,000,000$ a year. This, with other items of indebtedness, such as tourist and immigrant payments, was settled by an excess of exports over imports. At the present time, on the other hand, the United States has on loan abroad, in some form or other, probably $\$ 14,000,000,000$. This includes the credits advanced by the United States Government, the capital privately loaned since 1914, and the capital already invested before the war. Against this there is probably not over $\$ 1,000,000,000$ of foreign capital still remaining on investment in the United States. The country, therefore, is a net creditor to the extent of about $\$ 13,000,000,000$. The net interest due to the United States amounts to about $\$ 650,000,000$ a year. This credit amount clearly surpasses the net debit chargeable against the country on account of other invisible items. In order that the creditor may re-

ceive his interest, this should mean, therefore, an excess of merchandise imports over exports for the 
United States, unless the export of American capital (that is, loans to foreign countries) should continue on the abnormally large scale of the last few years. This, however, is not probable.

Owing to the war, the capital and interest account has become far and away the dominating item in the American balance of international payments. This account for the present, however, is subject to a special circumstance whose influence must be noted. By an understanding between the United States Treasury and the European governments concerned it was decided in 1920 to fund the credit advances of the Government to foreign countries. It was agreed, moreover, to include in the funding operation not only the credits thus advanced, but the interest payments thereon for three years. As a result of this agreement, interest on the government advances cannot be counted as a credit item in the balance prior to 1923. At any rate, it will have no effect upon the trade balance before that date.

The result of the postponement of the interest payment on government loans till 1923 will be at once apparent. Net interest payments on private capital represented for the United States a debit charge of about $\$ 200,000,000$ annually, during the years immediately prior to the war. Net interest payments on private capital now represent for that country a credit amounting to about $\$ 150,000,000$ a year. It is probably the case that approximately $\$ 4,000,000,000$ of American private capital is now 
invested abroad, while about $\$ 1,000,000,000$ of foreign capital still remains in the United States. The net interest payment on private capital now receivable by the United States, estimated at $\$ 150$,000,000 , is, however, not sufficiently large to counterbalance such debit items as immigrant remittances, believed to be much larger than in pre-war years, tourist expenditures, and miscellaneous charges. As a consequence, the several invisible items taken together still show a debit balance against the country. Moreover, any further advances of credit to Europe, either publicly or privately, or any increases in the other debit items would naturally have the effect of increasing this "invisible" net debit balance. For the present, therefore, and until 1923 at least, the balance of trade will continue to show an excess of exports over imports, although doubtless on a declining scale.

But under the present arrangement, the interest payments on government credits will make their appearance in 1923 in the balance. By that time, the total of government advances, including both the original credits and the unpaid and accumulated interest, will amount to somewhat over $\$ 12$,$000,000,000$. The annual interest charge on this will exceed $\$ 600,000,000$. When this is added to the credit side of the balance sheet of invisible items, the result will be a large net credit. The total of net interest payments receivable by the United States on both private capital and public 
advances will amount in 1923 to probably not less than $\$ 750,000,000$. Undoubtedly changes are likely to occur, as the years pass, in the invisible items other than interest payments. The shipping account, as a result of the expansion of the merchant marine, shows a small net credit at the present time. Its future is, however, uncertain because of changes in freight rates and other factors. At all events, as already suggested, the item of freight payments is not likely, for some time at least, to be relatively important. Remittances abroad by immigrants, now much above the pre-war average, are not expected to increase in the future. And there are sound reasons for believing that they will recede somewhat from the present level. Tourist expenditures, on the other hand, will probably increase rapidly, and very substantially surpass the pre-war figure. The net result will probably be the emergence of a large net credit balance on invisible items, on account of the interest payments which will be receivable subsequent to 1923 . This will mean that the anticipated overturn in the merchandise trade balance will then be not far distant.

The adjusting factor must naturally be the relative (gold) price levels of the several countries concerned. European prices must fall relatively to those of the United States, in order that European exports to the latter country may be encouraged, and European imports from the United States may be discouraged. By this means only will Europe 
be able, in the long run, to meet her interest obligations.

It is quite possible, and perhaps probable, that the overturn in the American balance of trade may be attended by no absolute reduction in the quantity of exports. It may follow as a result of a more rapid relative increase in imports. The latter may grow up to and surpass the exports. But change in the relative importance of exports and imports there must be. When the overturn will occur will depend on changes in the invisible items of the balance. Thus a moderate annual export of American capital for foreign investment would have the effect of postponing the transition in the balance of trade. For this and other possible reasons there is ground for believing that it may not appear until the later twenties. 


\section{CHAPTER III}

THE TRADE BALANCE OF THE UNITED KINGDOM

Having observed the principal features of the balance of trade of the United States, the great exporting and, until very recently, debtor country, let us now turn to a consideration of the trade balance of the United Kingdom, the great importing and creditor nation. The relative position of these two in their respective groups may be noted in the following summary of trade conditions in the principal capital-lending and borrowing countries.

Foreign Trade of Countries That Receive a Considerable Income from Their Foreign InvehtMents of Capital; dURing Calendar Year, $1913^{1}$

\begin{tabular}{|c|c|c|c|}
\hline \multirow[b]{2}{*}{ Country } & \multicolumn{2}{|c|}{ Merchandise } & \multirow{2}{*}{$\begin{array}{c}\text { Excess of Im } \\
\text { ports over } \\
\text { Exports }\end{array}$} \\
\hline & $\begin{array}{c}\text { Imports } \\
\text { (for consump- } \\
\text { tion) }\end{array}$ & $\begin{array}{c}\text { Exports } \\
\text { (domestic) }\end{array}$ & \\
\hline $\begin{array}{l}\text { United Kingdom } \ldots . \\
\text { Germany } \ldots \ldots \ldots \ldots \ldots \\
\text { France } \ldots \ldots \ldots \ldots \\
\text { The Netherlands } \ldots \ldots \\
\text { Belgium } \ldots . . .\end{array}$ & $\begin{array}{c}\$ \\
3,207,801,000 \\
2,563,354,000 \\
1,642,117,000 \\
1,574,990,000 \\
974,623,000\end{array}$ & $\begin{array}{c}\$ \\
2,556,106,000 \\
2,403,311,000 \\
1,326,950,000 \\
1,239,360,000 \\
717,152,000\end{array}$ & $\begin{array}{c}\$ \\
651,695,000 \\
160,043,000 \\
315,167,000 \\
335,630,000 \\
257,471,000\end{array}$ \\
\hline
\end{tabular}

1"Statistical Abstract of the United States, 1914," pp. 688, 689. 80 
TRADE BALANCE OF UNITED KINGDOM 81

Foreign Trade of Countries That Have Borrowed Heavily From Otiler Countries; during Calendar Year 1913

\begin{tabular}{|c|c|c|c|}
\hline \multirow{2}{*}{ Country } & \multicolumn{2}{|c|}{ Merchandise } & \multirow{2}{*}{$\begin{array}{c}\text { Excess of } E x \\
\text { ports over } \\
\text { Imports }\end{array}$} \\
\hline & $\begin{array}{l}\text { Imports } \\
\text { (total) }\end{array}$ & $\begin{array}{c}\text { Exports } \\
\text { (domestic) }\end{array}$ & \\
\hline & $\$$ & $\$$ & $\$$ \\
\hline $\begin{array}{l}\text { United } \text { States }^{1} \text { (in- } \\
\text { cluding Alaska, Ha- } \\
\text { waii, and Porto } \\
\text { Rico) }\end{array}$ & 893926000 & 2399684000 & 435758000 \\
\hline India $(\text { British })^{i} \ldots$ & $594,521,000$ & $792,359,000$ & $197,838,000$ \\
\hline Argentina $^{2} \ldots \ldots \ldots$ & $406,805,000$ & $466,582,000$ & $59,777,000$ \\
\hline Mexico $^{2} \ldots$. & $93,020,000$ & $129,971,000$ & $36,951,000$ \\
\hline
\end{tabular}

${ }^{1}$ Figures for the United States and India are for the fiscal year 1913-14. ports.

${ }_{2}^{2}$ For Argentina and Mexico the export figures comprise total ex-

The explanation which has already been offered of the excess of exports marking the balance of trade of the United States will apply, in the main, to the other countries in the capital-borrowing group. On account of the large accumulations of foreign capital invested within their borders, these countries are subject to net interest payments abroad. Certain other invisible debits also contribute toward the necessity of an offsetting credit balance of merchandise exports. That the trade balances of the capital-lending countries should be marked by an excess of imports is also quite to be expected. The existence of their balance of merchandise imports is, in the light of earlier statements, to be viewed as presumptive evidence of an excess of invisible credits over debits.

It was estimated by Sir George Paish in $\mathbf{1 9 1 0}$ that Great Britain had at that time about $\$ 15,000$,- 
000,000 of capital invested abroad. Germany and France, the countries then standing next as capital lenders, had about $\$ \$, 000,000,000$ each loaned abroad. Although the foreign investments of Holland and Belgium were much smaller they, nevertheless, were considerable. These importing countries, in addition to their receipt of interest from abroad, also enjoyed in varying degree large payments on account of shipping services and tourist expenditures. Prominent among the other importing countries at the time were Switzerland, Norway, Italy, and China. A large excess of imports characterized the trade balance of each of these countries in 1913. In the case of Switzerland, Norway, and Italy the import balance is to be explained, in large part, respectively, by tourist expenditures, merchant marine earnings, and the receipt of immigrant remittances from abroad. The import balance of China was largely the outcome of heavy borrowing of foreign capital. Canada, likewise, prior to the war, was an "immature" borrowing country, one whose annual interest payments abroad were still exceeded by the new capital borrowed each year.

It may be well, perhaps, to recognize that the investment of capital abroad, if successfully employed, confers benefits on the borrowing country no less than upon the one lending. Indeed, the benefit enjoyed by the former nation may be the greater. So long as capital is available for investment wherever in the world the best opportuni- 


\section{TRADE BALANCE OF UNITED KINGDOM 83}

ties exist for the development of industry and for the increased production of staple goods of worldwide consumption, it will not be a matter of serious concern where the ownership of such capital may rest. In his desire to emphasize this truth Mr. George E. Roberts, Vice-President of the National City Bank of New York, has the following to say: ${ }^{1}$

"Suppose a resident of New York should invest a portion of his surplus income in an industry in a distant state-say, California-which is about as far from New York in one direction as Europe is in the other. And suppose the industry is prosperous, but all the earnings are retained in it for development. It grows, it gives employment to an increasing number of people, the product is a useful article which enters into commerce, the income is all disbursed where the works are located, and as they grow a prosperous community grows up around them, with schools and churches and all the appurtenances of civilized life. How much sig. nificance attaches to the fact that the title to the property is in New York? This is not a purely imaginary picture; for that, substantially, was the way England's foreign investments were being employed before the war."

So long has the balance of trade of the United Kingdom been marked by an excess of imports, that we have come to look upon it almost as an immemorial institution. Nothwithstanding its apparent

${ }^{1}$ Roberts, "Our Obligations to Europe," an Address delivered at the Annual Meeting of the National Institute of Social Sciences, February 4, 1921 . 
antiquity and magnitude, however, the balance of imports is an outgrowth of the past century only. It was almost exactly one hundred years ago that the overturn occurred in the British trade balance. Prior to 1823, the foreign trade of the United Kingdom was characterized, in general, by an excess of exports. Although exact information relating to the extent and nature of British commerce before 1770 is meager, and notwithstanding the difficulty of making a thoroughly satisfactory comparison of exports and imports during the years immediately following, it is still possible, however, to trace the general course of trade from $1760 \mathrm{on}-$ wards. An important element of difficulty lies in the use at that time of two methods of ascertaining import and export values. The values of imports were given as "official"; that term representing a calculation from the quantities "according to rates of value fixed so long back as 1694." Imports continued to be valued in this so-called "official" manner till 1854. The values of exports, at first computed on the same basis, underwent a change in 1798. In that year the policy was adopted of estimating exports on the basis of their "real" value; the term "real" representing the actual value of the goods derived from a declaration at the time of exportation. The use of "real" values was not extended to imports until 1854. It is obvious at once that an accurate comparison of import and export statistics prior to that date is difficult, if not impossible, owing to the two methods of com- 


\section{TRADE BALANCE OF UNITED KINGDOM 85}

puting values. Attention will again be directed to this question when considering the balance of trade during the years 1798 to 1820 .

In his study of British trade in this early period Mr. Levi has presented in diagrammatic form the relation between exports and imports. In this diagram, which follows, it will be noted that the commerce of England is treated as distinct from that of Scotland and Ireland prior to 1778 , while from that time on to 1800 the trade of Great Britain is presented as isolated from that of Ireland.

\section{British Imports and Exports ${ }^{1}$.}

1760-1820

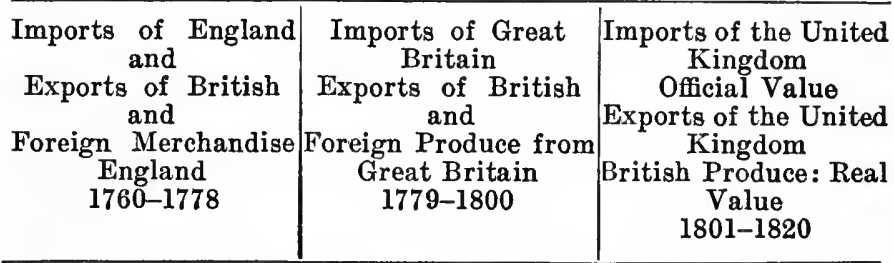

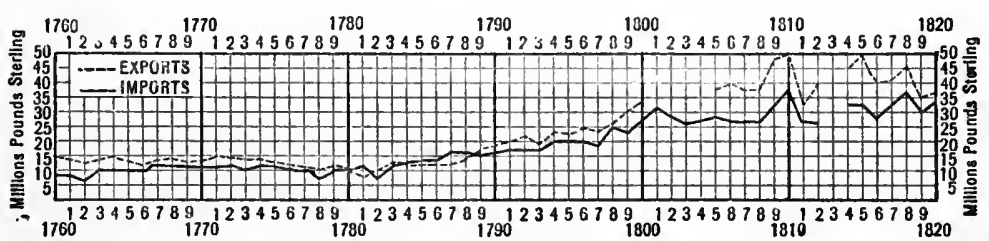

That the excess of exports that marked the trade of England in 1760 had already prevailed, in general, for a considerable time is clear. The "official" value of English exports and imports in certain

${ }^{1}$ Levi, "History of British Commerce," p. 27. 
typical years during the preceding century and a half is set forth in the following statement: ${ }^{1}$

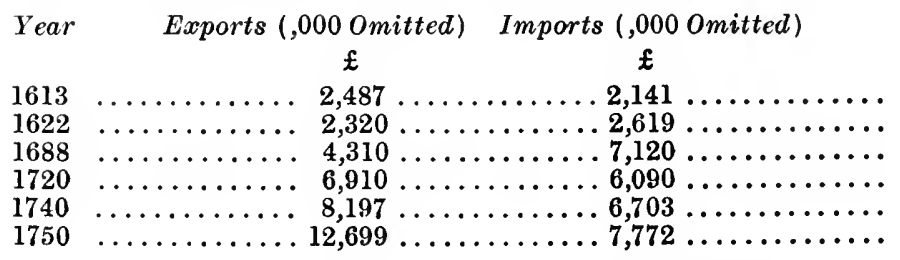

Before turning to a consideration of the overturn which occurred in 1823 in the balance of trade and to its subsequent development, let us take note of certain conditions which contributed toward the early balance of merchandise exports. The factor of prime importance was probably the international movement of capital, small though it was as compared with that of to-day.

The center of financial and commercial energy no less than the star of empire has steadily moved westward through the centuries. This center of economic activity was first located, in the modern age, in northern Italy, whence it moved, for a time, to Spain and Portugal, only to move on later to Holland, to France, and to England. It reached London about the close of the eighteenth century. "London was then the only market," Mr. C. K. Hobson states, "where any large quantity of floating capital was available to supply the requirements not only of domestic industry, but also of

${ }^{1}$ Cunningham, "Growth of English Industry and Commerce in Modern Times," vol. II, Appendix F. 
foreign governments and others." 1 Industrial development in England about 1800 was more advanced by a generation than on the Continent, and even more so than in America. It was British capital chiefly, for thirty years or more, that was available for the economic development of other countries. It flowed toward both Europe and America, to meet the financial needs of governments, to make possible the extension of transportation facilities, and to provide for the evolution of the economic organization.

Although the origin from which foreign investment arose was probably in commerce and while the first investors in foreign enterprise were, doubtless, merchants, it was inevitable that a differentiation should be made in time between the business of finance and that of trade. This process of specialization or differentiation of function, dating back to the Middle Ages, began probably with the accommodation afforded by the wealthy to princes. The next phase in this evolution of modern banking appeared in loans to prosperous men of business. Throughout the seventeenth century the principal borrowers were princes and potentates, and rich merchants who had the means of offering sound security. The process was assisted, in the course of time, by the growing multiplicity of the financial requirements of rulers of states, of municipalities, and of individual and joint-stock capitalistic enterprises. It was fos${ }^{1}$ Hobson, "The Export of Capital," p. 80. 
tered also by the increase in the number and importance of wealth-owners other than merchants, men willing to lend their capital to those who were in a position to use it productively. The purposes for which foreign capital was borrowed became as wide and varied as the area over which the capital was spread.

With the growth of modern industrialism and its accompanying expansion in the means of communication, progress of knowledge, and increase in governmental security, the number of persons able and willing to invest abroad rapidly increased. Such absentee investment, dating from the operations of the Florentines and Jews of mediæeval Europe, has become an important feature of modern economic life. As an example of the early lending transactions we may note the loan extended to King Henry V by certain Italian merchants. On May 13, 1404, "King Henry borrowed 1,000 mar'ks from ten merchants of Genoa, and for payment he allowed them to retain the duties on goods to be imported, and on wool, hides, wool-fells, cloth, and other goods, to be exported, by them in London, Southampton, and Sandwich for four months." 1 Five merchants of Florence also lent him 500 marks on the same terms. "In the following year sums to the same amount were lent by the same parties, and on the same terms." Edward IV and Mary obtained considerable loans from the Hanseatic League, and Elizabeth borrowed from Dutch ${ }^{1}$ Macpherson, "Annals of Commerce," vol. I, p. 614. 
merchants resident in the United Kingdom as well as from lenders in Hamburg, Cologne, and Antwerp. On the other hand, British capital, on occasion, was loaned abroad. Thus Queen Elizabeth in 1576 extended a loan of $£ 40,000$ to the state of Flanders.

In the meantime, with the growth of capital accumulation and the multiplication of the openings for investment, private borrowing as well was steadily increasing. It was stated before an official body in 1669 that considerable quantities of foreign funds were on loan privately in England. ${ }^{1}$ Much of the capital used in rebuilding London after the conflagration of $\mathbf{1 6 6 6}$ was said to be Dutch. Toward the latter part of that century a large portion of the capital of the Bank of England was subscribed by Dutch investors.

Gradually, however, the financial center of gravity was moving westward, the changes in this direction during the eighteenth century being noticeable. The financial requirements of the British Government became greater than ever before, and the principal of the national debt increased from 16 millions sterling in 1702 to 520 millions in 1802 . Much capital was also necessary for the construction of towns, factories, and canals, and for the development of agriculture and commerce. While the participation by foreigners in providing funds for these varied purposes was notable, the part taken by British capital became relatively more ${ }^{1}$ Hobson, "The Export of Capital," p. 85. 
important as the century wore on. It has been estimated that Dutch holdings of British securities amounted in 1776 to $£ 59,000,000 .^{1}$ Foreign investors also held considerable quantities of stock of the East India Company, South Sea Company, and Bank of England.

British capital, however, was not entirely engaged in domestic development, nor must it be assumed that the investment abroad of such capital was of negligible proportions before the nineteenth century. On the contrary, so early as 1690 exception was taken in certain quarters to the activities of the British East India Company on the strictly economic ground, that, in the absence of a plethora of capital, the funds employed in the Eastern trade might be much more usefully used in developing the resources of the country at home. It was felt that while the profit to the shareholders might not be so large if domestic and internal developments were furthered, the advantage to the community as a whole would be greater. Canals and improved roads were necessary, land was in need of drainage, and many manufactures were suffering for want of capital, at a time when the lucrative trade of India and the higher interest returns possible in Italy and France were attracting British capital abroad. At all events, colonial expansion, the growth of trade, and the foreign investment of capital went hand in hand.

As the position of the British money market ${ }^{1}$ Economist, February 15, 1913, p. 334. 
steadily became stronger, British capital was better able to compete with that of Holland, even in the domain of European loans. Thus, in 1735, a loan of 1,000,000 crowns was made by a group of London merchants to the Emperor Charles VI of Austria, the revenues of Silesia being hypothecated as security. ${ }^{1}$ And yet, despite the attraction exerted upon British capital by the investment opportunities of the European continent and by the trade of the colonies, the great bulk of British investments still continued to be made within the country.

The situation at the outbreak of the European revolutionary wars, in 1792 , has been summarized by Mr. Hobson, as follows: ${ }^{2}$

"Holland was still the chief financial center in which capital could be borrowed for foreign loans and other enterprises abroad. But she was soon to be displaced by London, whose resources, though temporarily drained by the Seven Years' War, and the War of American Independence, were constantly being increased through the rapid growth of trade and industry. . . . Small as was the extent of foreign investment, and insignificant as were the sums invested, when compared with presentday figures, there had nevertheless been a marked advance upon the investments of the seventeenth century."

The downfall of Amsterdam as the chief financial market of Europe was now near at hand. Napoleon's overthrow of the Dutch Republic, together

${ }^{1}$ Martens, Causes Célebres, p. 97.

"Hobson, "The Export of Capital," p. 93. 
with the imposition of a heavy indemnity, and the failure of the Bank of Amsterdam, had the effect of leaving London supreme. Yet, because of the very heavy drain of capital for war purposes during this period, the overseas investment of British capital proceeded relatively slowly. Although it is estimated that $\$ 80,000,000$ of the United States national debt was held in Great Britain in $1807,{ }^{1}$ and while other investments abroad, as well, were being made, the net movement of capital, nevertheless, during the first years of the nineteenth century was still into rather than away from Great Britain. Owing to the troubled condition of the European continent many continental investors sent their capital to England for safe-keeping, where it was invested in a variety of ways.

Prior to the close of the Napoleonic period, England was probably subject to a net debit charge on account of foreign investments of capital taken in conjunction with the interest payments thereon. The imports of foreign capital for domestic investment had far exceeded, during the preceding centuries, the export of British capital for overseas investment. By reason of this fact, the time had, doubtless, long since arrived when the annual interest charges payable by England had begun to surpass the annual importation of new foreign capital. Taking into consideration, therefore, both the imports and exports of capital, and the accompanying payments of interest to and by Great Brit-

${ }^{1}$ Bacon, Yale Review, November, 1900. 
ain, we should probably find, if complete data were available, that a net annual debit on this account was chargeable against the country about the time of the opening of the nineteenth century.

At the close of the Napoleonic Wars, Great Britain was able "not only to put by vast amounts of capital for her own internal development, but also to supply a powerful stream of capital to assist her less wealthy neighbors." With the conclusion of peace in 1815 an eager rush to borrow set in and the great money markets, particularly that of London, were flooded with new capital issues. From this time onward till the middle of the century, Great Britain was the only country in a position to lend large amounts of capital. Subsequent to 1815, therefore, the net movement of capital was increasingly outward.

There is a second invisible item in the British trade balance of that time that deserves notice. Shipping charges, including freights and other expenses, probably represented a net debit against England prior to 1750 . In this connection, too, in the absence of complete and satisfactory data it becomes necessary to rely largely upon estimates. The last half of the eighteenth century formed the time of transition during which British maritime preëminence was attained.

Although British seamen had already acquired a reputation for daring, as well as for a spirit of discovery and effectiveness, the British had not supplanted the Dutch and other maritime nations as 
the common carriers of the world's commerce before the middle of the eighteenth century. Various attempts had been made for centuries to build up the maritime resources of Britain. Navigation Acts of one kind or another were passed from the fourteenth century onward. It was during the reign of Elizabeth and under the influence of Lord Burleigh that the development of England's maritime power was first systematically undertaken. Burleigh left no side of the industrial or commercial life of the country unaffected in his attempt to increase both the amount of shipping and the number of seamen. The Navigation Act of 1651 was directly aimed at the maritime supremacy of the Dutch, yet it would appear "that the Dutch did not suffer perceptibly during the seventeenth century; their industry was reinforced to an even larger extent than that of England by religious refugees, and it was not till the first years of the eighteenth century that Holland attained the zenith of her commercial greatness. At that time she was still far ahead of England in the shipping and maritime resources at her command. Though England had not overtaken her rival, she had been gaining in the race. English shipping had developed enormously during the latter part of the seventeenth century, and it is, of course, possible that the Navigation Act contributed, along with other causes, to this result." 1 As a consequence of the several

${ }^{2}$ Cunningham, "Growth of English Industry and Commerce in Modern Times," vol. I, p. 213. 
wars during the latter part of the eighteenth century, England's maritime power was firmly established. The Dutch had suffered heavy losses both in the East and the West, while the French maritime resources had been put to a severe strain.

The item of shipping charges, at first a debit against England, doubtless came, therefore, to be a net credit to the advantage of the country about the time of the turn of the nineteenth century. With the continued growth of British shipping since that time, this credit has increased to large proportions.

Reverting to the diagram, already presented, showing the course of imports and exports between 1760 and 1820, we may conclude that the small excess of exports that normally marked British trade prior to 1800 was occasioned by the presence of a small debit balance against England on account of invisible items. The principal factors in this invisible debit account were the payment of interest to foreign lenders and shipping charges paid to the Dutch and other maritime powers. It is estimated that in 1774 British interest payments to the Dutch alone on war loans subscribed by the latter amounted to a million pounds a year. ${ }^{1}$ Foreigners, moreover, held large amounts of commercial and industrial stocks. In 1762 the total of such foreign holdings reached $£ 18,000,000$, on which the annual interest charges amounted to $£ 750,000$.

${ }^{1}$ Postlethwayt, Dictionary of Commerce, article "Holland." 
It will be recalled from the diagram that the British excess of exports, during this early period, attained its largest proportions during the later years. To some degree this must be attributed to British participation in the European wars and the War of 1812. These struggles imposed upon Britain a not inconsiderable invisible debit charge, in the form of an export of funds for the purpose of supporting British arms abroad or rendering loans and other help to allied countries. In part, too, and especially during the last years of the period, the condition is to be attributed to a withdrawal of capital from England by foreign lenders and to the rapid extension of British loans abroad. As evidence of the action of continental investors, we may note the fact that between 1813 and 1815 the holdings by foreigners of the British national debt were reduced by $£ 3,000,000{ }^{1}$ And, about the same time, as already suggested, British lending abroad began to assume proportions hitherto unprecedented. In consequence, notwithstanding the credit item growing out of the earnings of British ships at this time, there was probably a net invisible debit balance against Great Britain during the decade or more preceding 1820.

A further reason for the comparatively large excess of exports that characterized British trade during the twenty years following 1800, lies in the new policy adopted in $\mathbf{1 7 9 8}$ of computing the value of exports on the basis of their declared or "real"

"Hobson, "The Export of Capital," p. 96. 
values. Hitherto, as already stated, both exports and imports had alike been valued on an "official" basis, on the scale, that is to say, of values fixed in 1694. Import values continued, it will be recalled, to be ascertained on this basis till 1854 . The change introduced in 1798, however, in the process of computing export values had the effect at once of enlarging the statistics of exports, inasmuch as the general level of British prices in 1798 was considerably higher than that of 1694.

However, the very conditions which gave rise to an excess of merchandise exports at the moment were destined in a few years to bring about an overturn in the British balance of trade. With the continued growth of shipping, the item of freight payments became an increasingly important credit factor in the British account. With the subsidence of the investment of foreign capital in Great Britain, relatively, at all events, the payment of interest abroad became a less weighty debit item. And the extraordinary expansion in overseas investment of British capital, which began in 1815, hastened the time when the total of such investments would be so large that the annual interest receipts from abroad by Britain would exceed the new annual export of capital. It was to be expected, therefore, that the invisible, or non-commercial, items would soon begin to show a net credit balance in favor of Great Britain. This condition in turn would lead to the suggested transition in the trade balance. In the not remote fu- 
ture there would emerge an excess of merchandise imports which thereafter would continue indefinitely.

The change which appeared in England's balance of trade has been commented upon concisely by Mr. Hartley Withers. Since the early years of the nineteenth century, "the account has been complicated," he declares,

"by the growth of the amount that her debtors owe her every year for interest, and by the huge earnings of her merchant navy, which other countries pay by shipping goods to her, so that, by the growth of these items, the trade balance sheet has been turned in the other direction, and in spite of her lending larger and larger amounts all over the world she now has a balance of goods coming in. Interest due to England and shipping freights and the commissions earned by her bankers and insurance companies were estimated before the war [1914] to amount to something like 350 millions (pounds sterling) a year, so that she was able to lend other countries some 200 millions or more a year and still take from them a very large balance in goods." 1

That the overturn, which has thus been declared to be impending, did in fact appear shortly is revealed in the diagram below. Although imports slightly exceeded exports in the year 1823, it was not until 1825 that the final transition occurred. From that year onward the British balance of trade has been marked by an excess of imports.

${ }^{2}$ Withers, "International Finance," p. 83. 


\section{N17431S SONHOd SNOIרI}

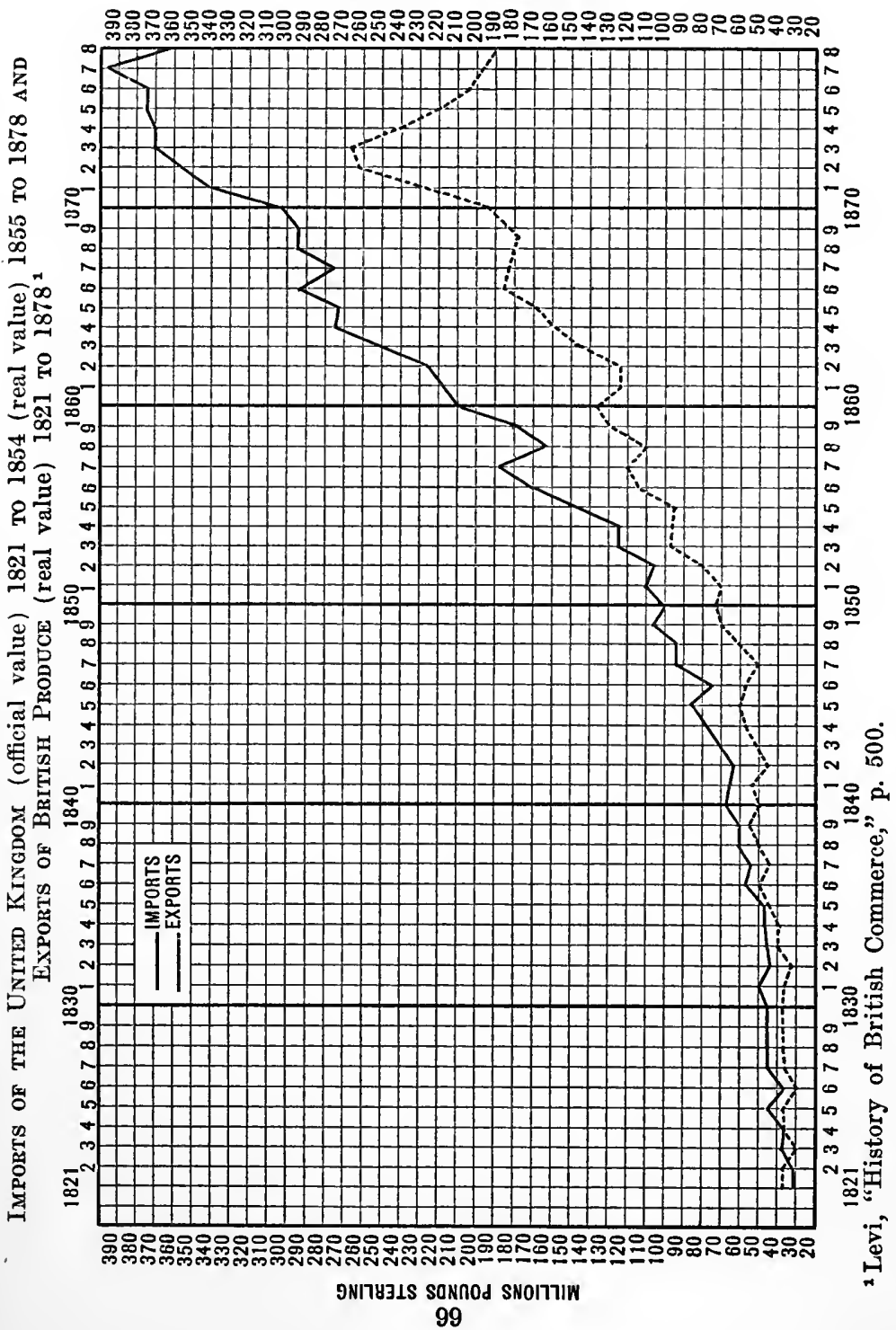


The British excess of imports over exports became so pronounced by 1875 that much anxiety was felt in many quarters lest "it should be an evidence of a state of trade disadvantageous to the economic condition of the country." Can it be, it was asked, "that the United Kingdom has been pursuing for years past a losing trade, and that at the end of the yearly transactions she finds herself in debt by so many millions?" There was no evidence, however, that England paid for this excess of merchandise imports in bullion. On the contrary, during the years 1860 to 1878 the net movement of gold was actually into England. The conclusion reached by Mr. Levi was that

"the best way of ascertaining whether the excess of imports into the United Kingdom indicates a state of trade disadvantageous to her economic condition, is to look to the foreign exchanges. If England did really owe the excess to foreign nations, would there not be a constant excess of bills of exchange on England in the foreign markets, and would not the exchanges in consequence be permanently against England? But the exchanges are generally in her favor, and the British sovereign holds its own against the money of all other countries. There is no reason, therefore, for any anxiety respecting the balance of trade in so far as the United Kingdom is concerned." 1

The general soundness of this conclusion is attested by the experience of the four decades since

${ }^{1}$ Levi, "History of British Commerce," p. 502. 


\section{TRADE BALANCE OF UNITED KINGDOM 101}

it was voiced. The excess of imports has in general increased with the years. During the six years preceding the World War, 1908-13 inclusive, the excess of merchandise imports over exports, exclusive of bullion and specie, averaged in value approximately $\$ 685,000,000$ a year. ${ }^{1}$ It is at once evident that such enormous balances could not well have been paid by England in gold. And, as if further to support the general conclusion, the actual net movement of gold and silver bullion and specie was into the United Kingdom rather than out of the country during these same years. Thus, during the period 1908-13, there was an excess of imports of bullion and specie over exports of the same averaging approximately $\$ 24,000,000$ per annum. There was, therefore, not only an absence of any drain of gold from Britain to settle the large debit against the country on account of merchandise trade, but, on the contrary, there was actually a considerable net inflow of gold. We are led, therefore, to anticipate that in the case of the United Kingdom there must have been at the time a large excess of invisible credits over invisible debits. The presence of such a net balance of invisible credits would serve to explain both the excess of visible or trade debits and the import of bullion and specie.

It is, of course, clear that the following diagram is not rigidly comparable in all details to the one

${ }^{1}$ British money throughout this chapter will be converted at the rate of $\$ 4.90$ per $\mathfrak{E}$. 
102 INTERNATIONAL TRADE BALANCE

which depicts British trade during 1821 to 1878. For the period since 1878 total British exports, inclusive of re-exports, are considered, for the period

Total Imponts and Total Exports of the United Kingdom, 1879 To 1913. (Bullion and Specie included)

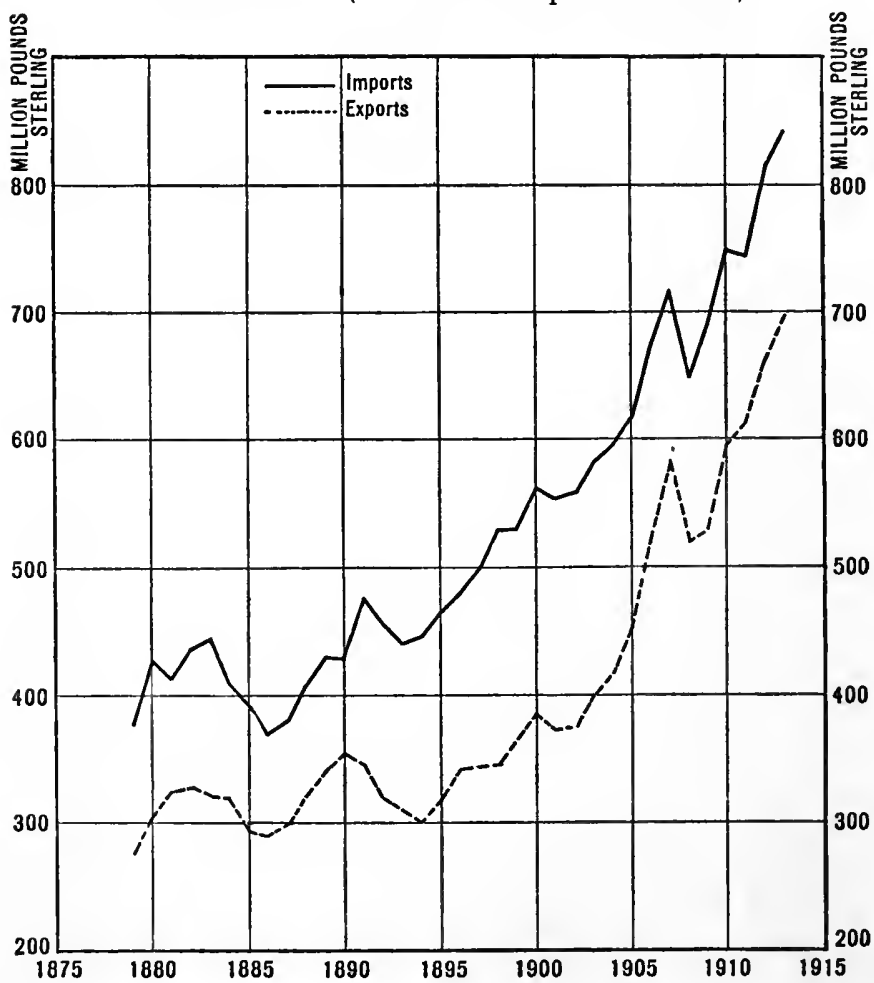

before 1878 exports of British produce only enter into the computation. The essential fact, however, is strikingly revealed that the disparity between imports and exports has persisted without inter- 


\section{TRADE BALANCE OF UNITED KINGDOM 103}

ruption since 1825, becoming, in the main, more pronounced through the century.

The connection between the British balance of trade marked by an excess of imports and the credit balance in favor of Britain on account of invisible items has been commented upon by $\mathrm{Mr}$. Edgar Crammond.

"It is difficult to avoid the conclusion," he declared in 1911, "that, so long as we [the British] remain the greatest creditor nation in the world, i. e., so long as we continue the investment of capital abroad on the present scale, so long as we do two-thirds of the carrying trade of the world and seventy per cent of the international banking business of the world, it will be impossible to prevent the importation of food-stuffs, raw materials, and manufactured goods, having an aggregate value greatly in excess of the commodities exported, unless we re-invest abroad the whole of our earnings from these sources." 1

Accordingly, inasmuch as the world's production of gold totaled in 1911 about $\$ 450,000,000$, it would not be possible, he added, to obtain full payment in gold for these services, which then had a value of about $\$ 1,500,000,000$ per annum, even if the British people desired it. It was inevitable, therefore, that the British should accept payment in the form in which the foreign debtors could best make it, and of which the British could make good use,

${ }^{1}$ Crammond, "British Investments Abroad," The Quarterly Review, vol. 215 , p. 58 . 
namely, in imports of food-stuffs, raw materials, or manufactured goods.

In attempting to construct a trade balance sheet for Great Britain, attention will first be directed to the visible or trade factors. Following the plan adopted in the preceding chapter, when considering the case of the United States, our undertaking will concern itself chiefly with the three-year period, 1911-13.

Merchandise imports into the United Kingdom averaged, in value, $\$ 3,580,000,000$ per annum during these years, while exports had an average annual value of $\$ 2,920,000,000 .^{1}$ The excess of imports of goods was equal, therefore, to about $\$ 660$,000,000 a year. Imports of gold and silver during these years had an average annual value of $\$ 337$,000,000 , while the export of these articles averaged $\$ 300,000,000$. The net movement of gold and silver was accordingly into Britain to the extent of $\$ 37$,000,000 a year. As a consequence, there was a total visible debit balance of about $\$ 700,000,000$ a year against the country during the period, on account of trade in merchandise and bullion. In the light of the foregoing we should expect to find a credit balance of invisible items approximating three-quarters of a billion dollars.

Prominent among the invisible factors to the credit of the United Kingdom is the receipt of interest on British capital invested overseas. It was

${ }^{1}$ Compiled from "Statistical Abstract for the United Kingdom, 1917," p. 75. 


\section{TRADE BALANCE OF UNITED KINGDOM 105}

estimated by Sir Robert Giffen in 1898 that Britain was then deriving about $\$ 450,000,000$ per annum in the form of interest from abroad. In the opinion of Sir George Paish, the British people were receiving in 1907 approximately $\$ 675,000,000$ from their foreign investments. The export of large amounts of additional capital was continued, however, with the result naturally that the interest receipts expanded also. According to the estimate of Paish, during the three years following 1907 Great Britain supplied other lands with a total of new capital amounting to $\$ 2,400,000,000$. It was his conclusion, expressed in 1911, that "if allowance be made, on the one hand, for the foreign capital employed in British companies both at home and abroad and in British loans, and, on the other, for the vast amount of private capital which the British people have placed abroad," the "net total of our investments in other lands would be not much short of $£ 3,500,000,000 . " 1$ However, owing to the difficulty of ascertaining the total amount of British capital privately invested abroad, Paish contented himself in his study with the investments for which there was documentary evidence. This total he placed at $£ 3,191,800,000$, or approximately $\$ 15,250,000,000$. The export of capital did not suffer abatement until the outbreak of the war. Accepting the foregoing total as substantially accurate for the year 1910, we may conclude that British

"Paish, "Great Britain's Capital Investments," Journal of Royal Statistical Society, January, 1911. 
foreign investments, by 1914, amounted to about $\$ 17,500,000,000$. The interest annually payable to the British people on this vast sum was probably not less than $\$ 900,000,000$ during that year.

This enormous accumulation of British capital abroad was the result of a long-continued export of funds. The outward movement of capital, as already intimated, has been especially marked since 1815. It has not been uniform, however, revealing at times rather sharp fluctuations. These variations in the quantity of capital invested abroad have occurred as a natural result or accompaniment of changes in general economic conditions both at home and abroad. The large wave of capital exports during the early seventies gave way during the years 1876-78 to an actual import of capital, the securities acquired in earlier years being either sold to foreigners, or not replaced upon redemption by new investments. The reviving efflux of capital of the eighties culminated in 1890, after which it fell off, though not uniformly, till 1901. After the slump following the South African War capital exports again increased, reaching an unprecedented scale from 1906 onwards till 1914.

of the total volume of British capital invested abroad by 1910 approximately fifty-one per cent had been supplied to foreign countries and fortynine per cent to countries of the empire. ${ }^{1}$ The country which had received the largest amount was

${ }^{1}$ Paish, "Great Britain's Capital Investments," Journal of Royal Statistical Society, January, 1911. 
the United States, where forty-two per cent of the aggregate of British investments in foreign countries was located. The next largest recipients of British capital were Canada, India, South Africa, Australia, and Argentina.

During the three years under review, 1911-13, the income of the British people in the form of interest on foreign investments probably averaged $\$ 850,000,000$ a year. This figure is somewhat less than that stated above as representing the income from foreign investments in the year 1914. The reason for this lies in the obvious fact that the average for the years 1911-13 would naturally be less than the figure for the later year, owing to the continued growth meanwhile of British foreign investments, which in turn would cause a gradual expansion in the volume of interest payments.

The receipt of interest from abroad by the British people has, of course, its offsetting counterpart in the outgo of interest from the United Kingdom to foreign lenders of capital invested within the country. This item, however, is relatively small, as is also the volume of foreign capital annually imported for employment in Britain. Yet it is true that a considerable increase occurred during the years preceding the war both in the number of foreign banks with branches in London, and in the volume of foreign accounts held by English banks. Foreign business firms operating in Britain also became more numerous. In the main it may be assumed, however, that the two comparatively 
unimportant factors, the import into England of foreign capital and the outgo of interest payments, approximately balanced one another. They may, therefore, be disregarded in the balance account. An important element closely related to that of interest payments, which cannot be neglected, is the annual export of new British capital. This item naturally is counted as a debit rather than a credit, owing to the fact that a loan abroad conveys to the foreign borrower a claim, at the time, on the goods or services of the lending country. During the two years 1909 and 1910 new or additional capital supplied by Britain to overseas countries amounted according to Paish, to $\$ 900$,000,000 per annum. This outward movement of capital assumed still larger proportions during the years immediately following. ${ }^{1}$ It is probable that not less than $\$ 1,000,000,000$ of capital was annually invested abroad during the period under review. Taking into account the movement of interest and capital into the United Kingdom and that of interest and capital out of the country, the result was a net debit against Britain amounting to about $\$ 150,000,000$ a year. This, it is obvious, represents the excess value of capital exports over interest receipts.

An important factor concerning which information is meager is the repayment of old loans. It can scarcely be assumed that in all cases where loans

${ }^{1}$ See Hobson, "The Export of Capital," and Withers, "International Finance." 
of capital are repaid the entire proceeds will be at once reinvested abroad. On the other hand, the estimate of Professor J. A. Todd ${ }^{1}$ that approximately $\$ 500,000,000$ of income accrued to the British people during 1913 through the withdrawal of British capital from foreign investment appears somewhat excessive. Thus it has been estimated, although admittedly subject, it is true, to a considerable margin of error, that during the first nine months of the war, August, 1914, to May, 1915, there was a net import, into the United Kingdom, of British capital from abroad amounting to about $\$ 500,000,000 .^{2}$ In view of the highly critical state of affairs during that nine-month period and the severe strain on England's financial resources, it is natural to look upon that sum as quite beyond the normal figure. And yet, notwithstanding the abnormal conditions which, presumably, made it unusually large, it was only some thirty per cent larger than that suggested for 1913. It is scarcely likely, therefore, that the return of capital incident to the repayment of old loans reached so large an amount as $\$ 500,000,000$ per annum during the years 1911-13. In the absence of conclusive data it may be estimated that the income of the British people on this account averaged not over $\$ 200,000,000$ a year. $^{3}$

'Todd, "The Mechanism of Exchange," p. 185.

"Hobson, "The War and British Foreign Investments," The Economic Journal, June, 1915.

${ }^{3}$ It may be noted in passing that Professor Todd estimated the interest received by the British people, in 1913, on their capital 
As has been stated already, the earnings of the British merchant marine in ocean transport service throughout the world represent an important credit item. According to the estimate of Giffen in 1898 , this amounted to about $\$ 450,000,000$ per annum. An independent calculation by the British Board of Trade on quite different lines, in 1903, made it only slightly less. In considering this item it is necessary to bear in mind the important fact that in the Board of Trade returns the values of imports include cost, insurance, and freight; whereas the values of exports include cost and only the charges of delivery on board ship. That is to say, the exports are entered in the trade statistics on the value basis of "Free on Board," or F.O.B., while imports are valued on the basis of "Cost, Insurance, and Freight," or C.I.F. As a result of this practice an apparent mystery arises in the fact that the statistics of the world's total of exports are less than for the world's total of imports. Obviously this is impossible, for it cannot be believed that more goods arrive in port than ever set sail. The Board of Trade explanation must be taken that the balance is to be accounted for by

invested abroad at about $\$ 600,000,000$. This estimate is $\$ 250$,000,000 less than that of the writer. The combined income, however, derived from the two sources, interest on foreign loans and repayment of old loans, amounted in the opinion of Professor Todd to only slightly less than the estimate reached in this study. It is quite possible that in Professor Todd's investigation certain amounts were looked upon as repayments of loans which, in this estimate, have been treated as interest. 
shipping charges; costs, that is to say, incurred after the goods have left any shore as exports. The Board of Trade in 1903 found an excess value of the world's imports over exports of about $\$ 1$,$120,000,000$. It was looked upon as representing freights, insurance, and certain incidental charges, such as harbor dues, cost of stores purchased abroad, etc. After making adequate deductions to cover these incidental charges and also the earnings of the ships of the British overseas countries, the Board of Trade arrived, as mentioned above, at a figure only slightly less than $\$ 450,000,000$, as the share to be credited in 1903 to the merchant marine of the United Kingdom. While subject to fluctuations from time to time, owing to variations in freight rates and changes in the general condition of world trade, this item of shipping earnings tended to increase, especially after 1909. It is probable that during the period under review it averaged not less than $\$ 500,000,000$ a year.

Among the remaining factors in the invisible account the principal one is the income derived by the United Kingdom in return for the services rendered to foreign countries by British banks, commission houses, and insurance companies. The vast business transacted through London on this account is paid for in the same way as any other goods or services rendered. These earnings amounted, it is estimated, to about $\$ 125,000,000$ per annum during the years under consideration. Lesser credit items appear in the form of govern- 
ment services, chiefly on account of India, the sale abroad of old ships, as yet not included in the official trade statistics, and private remittances, particularly from India, America, and Australia. In the opinion of Mr. Hobson the net sum to be credited to the United Kingdom under these heads was approximately $\$ 70,000,000$ during the year $1912 .{ }^{1}$ Inasmuch as that was the middle year of our threeyear period, the figure $\$ 70,000,000$ may be taken, therefore, as roughly representing the annual average.

Attention has been directed in an earlier connection to the so-called "boarding expenses," the expenditures incurred abroad by tourists and other travelers. While it is not possible to calculate definitely the amount annually spent abroad by British tourists, or the sums annually expended within the United Kingdom by colonial and foreign tourists, it has none the less been estimated, on the basis of the data available, that for Britain these two claims roughly balanced one another in 1913 at about $\$ 50,000,000$ a year. There are various other minor items concerning which the available information is meager. For one of them, however, it is possible to offer an estimate not altogether without merit. The amount of capital carried out of Britain by emigrants may be roughly calculated. The net excess of British emigrants from the United Kingdom over British immigrants into the country averaged about 270,000 a year during the ${ }^{1}$ Hobson, "The Export of Capital," p. 196. 


\section{TRADE BALANCE OF UNITED KINGDOM 113}

period in hand. It has been estimated by the United States Bureau of Immigration that, during the year's 1909-13, the per capita amount of money held by immigrants arriving in the United States from the British Isles was $\$ 82.00$. If this figure be taken as a basis of calculation it will appear that approximately $\$ 20,000,000$ of money was carried out of the country annually by emigrants. Moreover it may be assumed that the personal and other effects belonging to these outgoing settlers had in general a value equal to not less than one-half the value of the money carried. The net annual debit against the country on account of emigration amounted, therefore, according to this estimate, to about $\$ 30,000,000$.

It remains now to sum up the result of these various elements, both visible and invisible, which go to make the trade balance sheet of the United Kingdom.

(Figures denote millions, and annual averages for the years 1911-1913)

Visible Credits

Merchandise exports ...\$2,920 Merchandise imports . . $\$ 3,580$ Exports of gold and silver $\frac{300}{\$ 3,220}$ Imports of gold and silver $\frac{337}{\$ 3,917}$

Average annual excess of Visible Debits.....\$697

\section{Invisible Credits}

Interest on loans abroad. $\$ 850$ New loans abroad $\ldots \ldots \ldots 1,000$ Repayment of old loans... 200 Capital carried by emi-

Shipping receipts $\ldots \ldots \ldots, 500$ grants $\ldots \ldots \ldots \ldots \ldots, 30$

Commissions, banking, etc. 125 Boarding expense charges. 50

Sale of old ships, remittances, etc. ........... 70

Boarding expense receipts $\frac{50}{\$ 1,795}$

Average annual excess of Invisible Credits......\$715 
It was naturally not to be expected, for reasons more or less obvious, that an exact balance would be reached. There were various lesser items of the account that were entirely disregarded, owing to the absence of adequate information. Moreover, many of the figures presented above admittedly partake of the nature of rough approximations. The foregoing statement, however, does indicate the vast credits that annually accrued to the country as a result of its investments abroad, its shipping and its banking business. It has the effect, too, of supporting, from British experience, the contention advanced elsewhere that in every country there is a persistent tendency toward an approximate equivalence between total credits and debits.

That the war has had an effect upon the course of British commerce and on the nature of the balance of trade is, of course, to be expected: Considering both the vastness of the financial operations incident to the war and the important part taken by Britain in financing certain of her allies, it could not have been otherwise.

The most obvious effect of the war, perhaps, on British trade appeared in the enormous increase in imports, the practically stationary condition of exports, and the consequent sharp increase in the adverse trade balance. During the last three calendar years of the war, 1916-18, the excess of merchandise imports over exports reached the vast total of about $\$ 2,600,000,000$ per annum. This figure, it will be noted, is almost exactly four times larger 


\section{TRADE BALANCE OF UNITED KINGDOM 115}

than the corresponding total for the three pre-war years, 1911-13.

To meet her obligations growing out of this vastly increased volume of imports, it was necessary for Great Britain to have recourse to a variety of means. British holdings of foreign securities were sold in considerable part, a large quantity of gold was shipped out of the country in the course of the years, British loans were raised in the open markets of the United States and elsewhere, large direct advances were received from the American Government, and special arrangements were made with Argentina and other countries for the purpose of financing the importation into the United Kingdom of goods from them for a term of years.

However, notwithstanding the foreign loans that Britain was thus obliged to contract and in spite of various other altered conditions, the financial strength of Great Britain still remains intact. It is true, that, owing to the exigencies of the war, approximately $\$ 5,000,000,000$ worth of her previously held foreign investments have been sold. And it is also true that the United Kingdom, since 1914, has borrowed abroad about $\$ 7,000,000,000$; of which sum somewhat over $\$ 4,000,000,000$ took the form of advances by the United States Government. But, on the other hand, Britain has loaned during the war and post-war periods to her Allies and Dominions a sum equal to about $\$ 9,000,000,000$. To be sure, certain of these new investments, such as the loan to Russia, may be looked upon as of ques- 
tionable value. If the new debt incurred abroad by the United Kingdom be placed against the new investments, the total of her foreign investments is nearly as large as it was prior to the war. "A reasonable estimate," we are assured by Sir George Paish, "is that Great Britain now owns foreign investments to the nominal value of over $£ 5,000$ millions, against which she owes about $£ 1,500$ millions abroad, and that after allowing for the repayment of her foreign debt and writing off her doubtful investments the net and real value of her foreign investments is at least $£ 3,000$ millions." 1

The other items in the invisible account were also naturally affected by the war. Despite the loss in tonnage of the British merchant marine as a result of submarine activity, the income from shipping probably greatly increased, owing to the sharp advance in freight rates. The British share of the bankers' and brokers' commissions in the financing of international trade probably did not fall far, if at all, below the pre-war standard. On the other hand, earnings from insurance probably increased. The movement of emigration was much reduced during the war. Taking into consideration, therefore, all the invisible factors, it is probable that the United Kingdom enjoyed a larger excess of invisible credits at the time of the Armistice than before the war. ${ }^{2}$

\footnotetext{
${ }^{1}$ Paish, "The Economic Outlook in Europe," The Contemporary Review, September, 1919.

${ }^{2}$ See estimates of Crammond, The Quarterly Review, July, 1918, and Keynes, "The Economic Consequences of the Peace," p. 253.
} 


\section{TRADE BALANCE OF UNITED KINGDOM 117}

While, it is true, the depreciation of the pound sterling in certain countries is set forward as evidence of a large debit balance against England, it must be remembered that there are other reasons as well for this. The monetary conditions within the country, marked by a depreciation of British paper money, must be held to be responsible in no small part for the state of the foreign exchanges. And, moreover, the depreciation of the sovereign, especially in the United States, is to be attributed in part to the fact that Great Britain, in granting large credits to countries on the European continent, has been obliged to obtain credits from America and elsewhere. Great Britain has been lending her credit to her European neighbors, to enable them to purchase abroad the goods of which they were urgently in need. Britain is the one European belligerent nation which has succeeded, through a vigorous taxation policy and a sound balancing of her budget, in showing a surplus of tax revenues over expenditures. The British export trade ras also shown unmistakable signs of recovery. That sterling exchange should, therefore, have fallen so low and have remained so far below par points to the conclusion suggested above that Great Britain has, in no small part, been financing the trade of her European Allies.

Concerning this phase of British financial policy, Professor J. H. Williams has declared :

"England has used her improved position in foreign trade to assume a considerable share of the 
unfunded indebtedness of the continent of Europe to us [United States], rather than to pay off her own indebtedness here. This is indicated by the fact that New York banks and dealers have sold to London in large part their holdings of francs, marks, and other currencies; and for this reason sterling has probably ruled somewhat lower than its own merits would warrant and the other European exchanges somewhat higher." 1

It is of interest to note further that in the opinion of this recognized American student of international trade these sterling operations indicate "that in spite of the war Great Britain has been recovering her traditional position as the world's money market; and this recovery is strong evidence that triangular offsets are to-day operating upon our own international balance." The action of London in assuming, in part, the burden of other countries, the action of New York bankers in converting much of their holdings of other exchanges into sterling credits, together with the fact that the United States, meanwhile, had a favorable balance of trade with Europe and an adverse balance with non-European countries, must not be looked upon as a new element in American international relations. On the contrary, these operations represent the revival of pre-war conditions and pre-war practice.

${ }^{1}$ Williams, The Review of Economic Statistics, Supplement, June, 1921, p. 208. 


\section{CHAPTER IV}

\section{THE CANADIAN BALANCE OF TRADE}

It was stated in an earlier chapter that Canada, a so-called immature borrowing country before 1914, is passing through a transitional stage from which she is about to emerge a mature debtor nation. And with this transition there would appear, it was suggested, an accompanying readjustment in her balance of trade. Her normal pre-war excess of merchandise imports would come to be superseded by a normal excess of merchandise exports. This change in the Canadian trade balance would be similar to that which occurred in 1874 in the balance of trade of the United States. And the factors which led to the American trade readjustment at that time would in a general way apply also to the Canadian situation.

Just as the American excess of merchandise imports down to 1874 may be attributed in large part to the great volume of capital borrowed by the United States from abroad, so likewise the Canadian excess of imports prior to 1914 may be explained by the inflow of foreign capital into the Dominion. Similarly, the chief factor which gave rise after 1874 to an export balance in the United States is about to manifest itself in like manner in 
Canada. This factor appears in the tendency of interest payments to overtake and surpass in the course of time the volume of new capital annually invested. The change in the trade balance of the Dominion will ultimately occur as a result indirectly of the very accumulation of foreign capital investments within the country. The increasing interest payments by Canada on such investments will eventually surpass in volume, and that probably in the not remote future, the new foreign capital invested annually.

That Canada has been an increasingly attractive field for foreign investors is well known. At the end of the year 1910, it was stated by Sir George Paish that British capital had been invested in Canada to the extent of approximately $\$ 1,800$,$000,000 . .^{1}$ In March, 1915, the opinion was unoffcially expressed by Sir Edmund Walker, President of the Canadian Bank of Commerce, that British investments in Canada probably amounted to not less than $\$ 2,750,000,000$. It must be added, however, that Sir Edmund Walker included in this total the indebtedness of Canada to the continent of Europe, inasmuch as continental investing in the Dominion has been carried out chiefly through London. Such investments of the countries of the continent, however, amounted in 1913 to not over $\$ 175,000,000 .^{2}$ After making the proper adjust-

"Paish, "Great Britain's Capital Investments," Journal of Royal Statistical Society, January, 1911.

2"Dominion's Royal Commission Reports" (Cd. 8458), p. 417. 
ment on account of this item, it will be noted that during the years, 1910-13, British investments in Canada increased about $\$ 775,000,000$, or nearly forty-five per cent. An even greater rate of increase is to be noted in the flow of American capital into Canadian channels. Whereas the approximate volume of United States investments in Canada amounted in 1909 to $\$ 257,000,000$, the estimate for 1913 was $\$ 637,000,000 .^{1}$ This represents an increase of about 127 per cent during the four years.

It is probable that during the three years immediately preceding the outbreak of the World War Canadian borrowings of foreign capital averaged well over $\$ 300,000,000$ per annum. And in 1913, in the course of an address in Toronto, Sir George Paish predicted that within fifteen years new or further British investments amounting to $\$ 2,500,000,000$ would be made in Canada. The war obviously will have the effect of obstructing the fulfillment of this prediction.

Canada may be likened to a young man, energetic, ambitious, and in possession of an extremely valuable but unimproved estate, for the improvement of which much capital is needed. To complete the analogy we must picture a parent willing to lend the capital necessary for the development of the estate. During the period of construction, the young man has been taking care of the interest charges on his indebtedness readily enough through the contraction of new loans. Obviously

${ }^{1}$ Field, "Capital Investments in Canada," p. 25. 
our young man cannot permanently overlook the fundamental consideration, that his construction expenditures must be justified in the end by an increased production of wealth at least proportional to the investments: that is, he must provide eventually for debt charges from current income, and not as heretofore from capital account.

Even before the World War brought home to Canada the necessity of an economic readjustment, a halt had been called in the almost headlong construction of railways and other capitalistic plants. Indeed, this began several years before August, 1914. A well-timed hint from certain prominent English investment houses in the summer of 1909 was taken to heart by Canadians. These British banking firms, interested in Canadian enterprises, agreed not to undertake any new Dominion flotations for several months. During that time the flow of British capital to Canada, through its principal channel, practically ceased. "The cause of the financiers' decision," declared Mr. F. W. Field, "was undoubtedly the unusually heary borrowing by Canada, its tendency to exceed due bounds, and the attempt to market a few worthless securities among a large number of good ones." 1 Enjoying for so long a time an almost unlimited credit in Great Britain, it was quite natural for Canada to invest heavily, oftentimes blindly, in development works. So rapidly did this take place that Canada, notwithstanding a population of less than 9,000,-

1 Field, "Capital Investments in Canada," p. 168. 
000, had in 1914 three transcontinental lines. She enjoyed the distinction of having more railroad mileage per capita than any other country in the world. The reciprocal fact is obvious that this is a questionable distinction, since Canada, therefore, must have fewer people per railway mile than any other country. Railroad construction clearly had been carried to a point far in advance of immediate requirements. Indeed, it is maintained that general railroad construction in Canada was five to ten years ahead of the demand. The total mileage increased from 17,657 in 1900 to 29,304 in 1913 , or nearly 65 per cent. During the same period, the capital liability of railways increased from $\$ 784,042,799$ to $\$ 1,531,830,692$, or substantially 100 per cent. Meanwhile, however, the population of the country increased only about 43 per cent. The development of railroads was accompanied by an expansion in the industrial field and an extension of building throughout the country.

Feeling that construction enterprises had outstripped the population demands, many realized that it was time to demonstrate by increased production the wisdom of previous years of building. The tightening of the European money markets, owing to the Balkan crisis, and the difficulty of obtaining the usual supply of capital from Great Britain on normal terms, doubtless brought about the readjustment earlier than would otherwise have been the case. Among the various evidences of reduced activity during the year 1913 may be 


\section{INTERNATIONAL TRADE BALANCE}

noted a distinct contraction, particularly in the west, in the volume of building permits, a decline in bank clearings, and an increase in the number of commercial failures.

While engaged in the enforced but thoroughly wholesome process of economic readjustment, Canada suddenly found her task greatly complicated by the outbreak of the war. Owing to the unprecedented demand on the world's capital, due to the war, Canada's financial embarrassment increased. The war hastened the economic transition, and it undoubtedly had the effect of differentiating between the essentially sound investment enterprises and those based on uneconomic foundations.

In computing Canada's balance of international debits and credits the items to receive first attention will be the visible exports and imports. In the following statement these are tabulated for a series of fiscal years. ${ }^{1}$

(Figures denote millions)

\begin{tabular}{|c|c|c|c|c|}
\hline & 1911 & 1912 & 1913 & 1914 \\
\hline Imports: & & & & \\
\hline Merchandise $\ldots \ldots \ldots \ldots$ & $\$ 462.0$ & $\$ 533.3$ & $\$ 686.6$ & $\$ 635.5$ \\
\hline Bullion $\ldots \ldots \ldots \ldots$. & 10.2 & 26.0 & & 15.2 \\
\hline Total $\ldots \ldots \ldots \ldots$ & $\$ 472.2$ & $\$ 559.3$ & $\$ 692.0$ & $\$ 650.7$ \\
\hline Exports: & & & & \\
\hline Merchandise & $\$ 290.0$ & $\$ 307.7$ & $\$ 377.1$ & $\$ 455.4$ \\
\hline Bullion ........ & 7.2 & 7.6 & 16.1 & 23.6 \\
\hline Total...$\ldots \ldots \ldots$ & $\$ 297.2$ & $\$ 315.3$ & $\$ 393.2$ & $\$ 479.0$ \\
\hline Net $\begin{array}{c}\text { Excess of Imports } \\
\text { (merchandise and bul. }\end{array}$ & & & & \\
\hline lion) $\quad \ldots \ldots \ldots \ldots \ldots$ & $\$ 175.0$ & $\$ 244.0$ & $\$ 298.8$ & $\$ 171.7$ \\
\hline
\end{tabular}

${ }^{1}$ Report of Department of Trade and Commerce, 1912, pt. 1, pp. 28-37. “Canada Year Book, 1913," pp. 228, 232, 233. 
For the three years ending March, 1913, the average annual excess of imports was $\$ 239,000,000$. Let us note the invisible items of Canada's balance sheet, in order to discover the nature of the invisible account. Naturally we shall expect to find an excess of credits approximating in value the excess of merchandise imports.

Among the "invisible" items, the most important are the flow into the country of borrowed foreign capital and the outflow of interest and dividend charges to the owners of such capital. It will be recalled that, in the opinion of Sir Edmund Walker, the total of British and other European investments in Canada was approximately $\$ 2,750,000,000$. From the investigations of the Editor of the Monetary Times, it appears that the estimated total investments of the United States in Canada, in 1913, amounted to $\$ 636,903,952 .{ }^{1}$ If we accept the figure $\$ 3,400,000,000$ as representing, within a slight margin of error, the total of Canadian indebtedness abroad, it will be possible to estimate with reasonable approximation the annual interest charges. Accepting $4 \frac{1}{2}$ per cent as the average interest rate, ${ }^{2}$ Canada's interest payments abroad during 1913 amounted to about $\$ 148,000,000$. This amount, however, must be somewhat diminished by reason of the fact that we are seeking the average for the period. Obviously, the annual interest pay-

'Field, "Capital Investments in Canada," p. 25.

${ }^{2}$ This rate was advanced by Sir Edmund Walker, in a private communication, as a fair basis for calculation. 
ments during the earlier years were less than the figure noted, owing to the subsequent swelling of the total investments within the country. Making adequate adjustment to meet this fact, there emerges as the average annual interest charge during the years $1911-13$, approximately $\$ 125,000$,000. It has already been mentioned that, during the year's immediately before the outbreak of the war, Canadian borrowings of foreign capital probably averaged well over $\$ 300,000,000$ per year. Therefore, during that period it would seem that Canada was receiving annually a net credit, from the two items under consideration, of about $\$ 175,000,000$.

Another invisible item in Canada's balance sheet is the capital carried into the country by American farmers moving into the Canadian West. In his Budget Speech of May 12, 1913, Sir Thomas White, the minister of finance, estimated that this class of immigrants took with them into Canada capital to the extent of $\$ 1000$ per capita. The average annual number of immigrant arrivals from the United States during the three years 1911-13, was 131,000 . If the estimate of the finance minister be accepted, account must be taken of this invisible credit of $\$ 131,000,000$ per annum during the selected period. From this amount, however, a deduction must be made for the "effects and cash" of emigrants from Canada, most of whom enter the United States. During the three years 1911-13, the average annual number of immigrant arrivals 
in the United States from Canada was 62,790. There is also a considerable return movement back into the United States on the part of American citizens who have emigrated to Canada. During the two years ending June 30,1911, this back-flow of Americans from Canada was equal, numerically, to one-third of the outward movement. ${ }^{1}$ If this ratio be adopted as approximately applicable during the period under consideration, the number of American emigrants returning from Canada averaged about 43,000 per year. The total arrivals, therefore, in the United States from Canada during these years averaged 105,000. The fact should be borne in mind that the typical Canadian emigrant seeking a home in the United States, is a man possessing little beyond ambition, and that the American returning from a brief sojourn in Canada is normally one who has been disappointed in his search for better conditions. Accordingly, the estimate that these two classes of arrivals in the United States bring with them capital not exceeding $\$ 500$ per head will probably be deemed liberal. Proceeding on this assumption, the total capital carried annually from Canada into the United States by Canadian emigrants and American settlers returning from the Dominion may be estimated to average at the time about $\$ 50,000,000$. On account, therefore, of the immigration and emigration movements between the two countries, there was a resultant

${ }^{1}$ Husband, American Economic Review, Supplement, March, 1912, p. 84. 
net invisible credit of about $\$ 80,000,000$ per year into Canada. It must be admitted that this is, in a degree, a conjectural estimate.

An invisible item which, because of insufficient data, must be approached with caution is that of private remittances both into and out of Canada. During the three fiscal years 1911-13, the value of money orders issued in Canada and payable in other countries averaged annually somewhat over $\$ 32,000,000$; whereas the value of money orders issued in other countries and payable in Canada, during the same period, averaged each year $\$ 8,700$,$000 .^{1}$ From these items accordingly we find an average net outflow from Canada of $\$ 24,000,000$. There is no available information, however, which shows what proportion of these orders is represented by business and private remittances nor is it at all certain that all private remittances flowed through this channel.

There are other invisible items sufficiently important to merit notice. Canada is obliged each year to meet considerable charges on account of the carriage in foreign ships of much of her overseas trade. On the other hand, the annual earnings of the Canadian merchant marine represent a credit of some importance. Again, Canada each year serves as a vacation land for thousands of tourists, whose various expenditures may be regarded as a not unimportant credit. Naturally, there is also a corresponding debit in the expendi3"Canada Year Book, 1913," p. 403. 
tures by Canadians in the United States and Europe.

Unfortunately, however, there are no published statistics nor even official estimates pertaining to these items. Accordingly the attempt to handle them must be based, in considerable degree on reasonably sane guesswork.

For the purpose of this inquiry the following compromise plan will perhaps be deemed reasonable. It is probably true in respect to the shipping items that the annual charges which Canada was called upon to meet, for services rendered by foreign shipping interests, were in excess of that portion of the annual earnings of Canadian ships derived from the carriage of goods of foreign countries. At the same time, it was doubtless true that the expenditures of tourists and other visitors annually in Canada surpassed in volume the outflow of funds on account of the expenditures of Canadians in other countries. Accordingly we may offset the former balance against Canada, on account of shipping charges, by the latter balance in favor of Canada. This adjustment probably involves a not unduly large margin of error. The results may be presented in tabular form as shown on page 130 .

As was the case in the foregoing chapters, when considering the balance sheet of the United States and the United Kingdom, so here again we note that an exact balance has not been reached. In this instance the discrepancy may in part be attributed to the margin of error admittedly present 


\section{Balance Sheet of Canada}

Figures Represent Annual Averages for the Period 1911 to 1913 (Figures denote millions)

Visible Credits and Debits

Exports and imports of merchandise, including bullion:

Average annual excess of imports ...............239

Average annual excess of Visible Debits ...........\$239

Invisible Credits and Debits

New capital imported and interest payments payable abroad: average net credit ...................... 175

Capital carried into Canada by immigrants and out by emigrants: average net credit ................. 80

Payments effected through the issuance of money orders: average net debit ........................ 24

Payments on account of ocean freights and earnings of Canadian ships; expenditures in Canada by tourists, etc., and abroad by Canadians; estimated to balance

Average annual excess of Invisible Credits ..........\$23I

in the calculation in respect to the shipping and tourist items.

Canada owes much to the British investor, if only because he has almost entirely financed its extensive railway system. In contrast to the experience of India, however, Canada, despite its heavy borrowings in London on account of railways, does not import its railway materials to any large extent from the United Kingdom. Canada, having developed an important metallurgical industry, is able to supply in large measure the rails, locomotives, and other equipment required for domestic use. The following figures indicate the relative unimportance of the Canadian market to the British producer of railroad materials. ${ }^{1}$

${ }^{1}$ Hobson, "Export of Capital," p. 14. 
THE CANADIAN BALANCE OF TRADE 131

\begin{tabular}{|c|c|c|c|}
\hline Year & $\begin{array}{l}\text { Canadian Railway } \\
\text { Issues in London }\end{array}$ & $\begin{array}{l}\text { Imports of Iron } \\
\text { and Steel Railway } \\
\text { Bars and Rails } \\
\text { into Canada: From } \\
\text { United Kingdom }\end{array}$ & Total \\
\hline $\begin{array}{l}1907 \ldots \ldots \ldots \\
1908 \ldots \ldots \ldots \\
1909 \ldots \ldots \ldots \\
1910 \ldots \ldots \ldots \\
1911 \ldots \ldots \ldots\end{array}$ & $\begin{array}{r}£ 2,020,100 \\
12,395,500 \\
8,060,500 \\
5,525,800 \\
19,608,200\end{array}$ & $\begin{array}{r}\mathbf{1 4 6 , 3 1 1} \\
17,459 \\
64,328 \\
58,944 \\
15,024\end{array}$ & $\begin{array}{r}£ 373,573 \\
255,617 \\
159,496 \\
279,675 \\
179,197\end{array}$ \\
\hline
\end{tabular}

The trade statistics of Canada show that British shipments of other kinds of railroad materials and of general merchandise have in the main been equally unimportant compared with the amount obtained elsewhere. It is apparent upon examination of the merchandise import figures of Canada that England does not export goods to the Dominion equal in value to the capital supplied. The following table shows the total imports, exclusive of coin and bullion into Canada from the United Kingdom and the United States during a series of years.

(Figures denote millions)

\begin{tabular}{|c|c|c|c|}
\hline & \multirow{2}{*}{ Fiscal Year } & \multicolumn{2}{|c|}{ Imports into Canada from: } \\
\hline & & United Kingdom & United States \\
\hline $\begin{array}{l}1910 \\
1911 \\
1912\end{array}$ & $\begin{array}{c}\ldots \ldots \ldots \ldots \ldots \ldots \\
\ldots \ldots \ldots \ldots \ldots \ldots \ldots \\
\ldots \ldots \ldots \ldots \ldots \ldots \ldots\end{array}$ & $\begin{array}{l}\$ 95.7 \\
110.6 \\
117.2\end{array}$ & $\begin{array}{r}\$ 233.0 \\
284.3 \\
342.2\end{array}$ \\
\hline
\end{tabular}

To facilitate a comparison of Canada's separate trade balances with the United Kingdom and the United States, statistics are presented in the following statement showing exports from the Do- 
minion to the two countries, during the years 1910 to 1912 , again exclusive of coin and bullion.

(Figures denote millions)

\begin{tabular}{|c|c|c|c|}
\hline \multirow{2}{*}{\multicolumn{2}{|c|}{ Fiscal Year }} & \multicolumn{2}{|c|}{ Exports from Canada into: } \\
\hline & & United Kingdom & United States \\
\hline $\begin{array}{l}1910 \\
1911 \\
1912\end{array}$ & $\begin{array}{c}\ldots \ldots \ldots \ldots \ldots \ldots \\
\cdots \cdots \cdots \cdots \cdots \cdots\end{array}$ & $\begin{array}{r}\$ 149.6 \\
137.0 \\
151.8\end{array}$ & $\begin{array}{r}\$ 110.6 \\
112.2 \\
113.0\end{array}$ \\
\hline
\end{tabular}

It will be noted from the above tables that Canada, during the period under consideration, exported goods to Great Britain in excess of goods imported from that country to the extent of about $\$ 40,000,000$ per year. At the same time the excess of Canadian imports from the United States over exports to that country showed an annual average value of about $\$ 175,000,000$. These facts lend support to the common assertion that English loans to Canada help that country to finance its American trade. English capital, therefore, "passes to Canadians in the form of American goods."

Aside from the influence of geographic proximity, there is an important reason for the disparity in the importation into Canada of American and British goods. In the past, the great bulk of British investments have gone into government securities and railway and industrial bonds, comparatively little into industrial stocks, which carry the technical management. American capital, on the other 
hand, has entered Canada chiefly as branch factories and other outright industrial investments. This question is discussed in the report of a former British Trade Commissioner in Canada. "The purchase of government securities and municipal bonds," he declared, "and even of the bonds and shares of the great Canadian railroads-the forms which British investment has hitherto principally taken-operates less directly and immediately to stimulate trade than the investment of capital in varying amounts over a wide range of industrial concerns, together with the establishment of branch factories and agencies of all sorts, which has been characteristic of the form of American interest in the development of Canada." 1

On account of the great increase in the rate of flow of British and American capital into Canada during the past decade, Canadian imports have grown at a faster rate than exports, as the following statement will show.

(Figures denote millions)

\begin{tabular}{|c|c|c|c|c|c|c|}
\hline \multicolumn{2}{|c|}{ Years } & \multirow{2}{*}{$\frac{\text { Total Exports }}{\$ 196.5}$} & \multirow{2}{*}{$\frac{\text { Total Imports }}{\$ 190.4}$} & \multicolumn{3}{|c|}{$\begin{array}{c}\text { Ratio of Exports to } \\
\text { Imports }\end{array}$} \\
\hline 1901 & ..... & & & 103.19 & per & cent \\
\hline 1902 & $\ldots \ldots$ & 211.6 & 212.3 & 99.70 & 6 & 6 \\
\hline 1903 & $\ldots \ldots$ & 225.8 & 241.2 & 93.63 & “ & “ \\
\hline 1904 & $\ldots \ldots$ & 213.5 & 259.2 & 82.37 & " & " \\
\hline 1911 & & 297.2 & 472.2 & 62.93 & 6 & $" 6$ \\
\hline 1912 & & 315.3 & 559.3 & 56.38 & “ & " \\
\hline 1913 & $\ldots \ldots$ & 393.2 & 692.0 & 56.83 & “ & 6 \\
\hline 1914 & $\ldots \ldots$ & 479.0 & 650.7 & 73.60 & “ & " \\
\hline
\end{tabular}

${ }^{1}$ Quoted in Field, "Capital Investments in Canada," p. 192. 
This situation, however, cannot persist indefnitely. In the not distant future, as mentioned elsewhere, the present disparity in value between exports and imports must shrink, then disappear, and later be followed by an excess of exports. For an indefinitely long period thereafter the Canadian trade balance will continue to be marked by excessive exports.

Owing to conditions growing out of the war, the trade balance of the Dominion, for several years, was marked by an excess of exports. While the time perhaps has not yet fully arrived when Canada, as a mature borrower, will continue normally to export goods to a larger value than her imports, yet this readjustment is not far distant. If the practice adopted by necessity during the war of raising capital at home be continued and expanded and the inflow of foreign capital fail to reach the pre-war level this transition would probably be hastened.

Variations in the external trade of Canada since 1914 have been notable and they illustrate the extent to which the trade and industry of the Dominion have been affected by war conditions. The aggregate trade, made up of imports for home consumption and total exports, had an average yearly value of $\$ 872,000,000$ during the three fiscal years 1911-13. Yet during the period 1917-19, it reached the annual average of $\$ 2,249,000,000$. This increase, striking as it is, is not more significant than the change which appeared in the relative im- 
THE CANADIAN BALANCE OF TRADE 135 portance of exports and imports. During the three years ended in 1913, there was an import balance which, as has been pointed out above, averaged

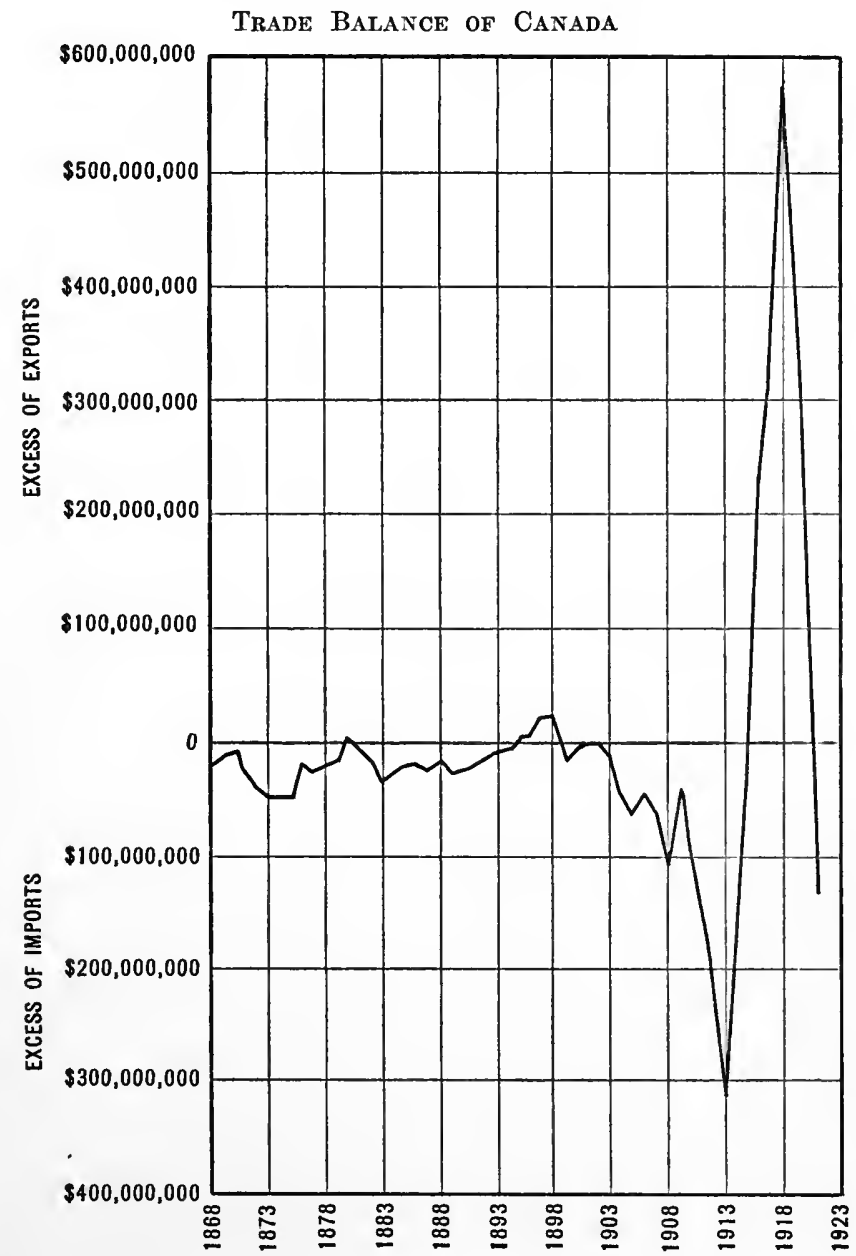


$\$ 239,000,000$ a year. An export balance, however, appeared in the fiscal year 1915-16. The excess of exports grew to such proportions that the annual average for the years 1917-19 amounted to $\$ 409$,000,000 . The foregoing chart reveals the general character of Canada's trade balance from the time of Confederation to 1921. The chart does not indicate the aggregate volume of imports and exports, but merely the difference between them.

The excess of exports, which increased so rapidly after its appearance in 1915, persisted till the close of the fiscal year 1919-20. During the succeeding twelve months, ending in March, 1921, it was superseded by a small excess of imports, amounting to $\$ 30,000,000$.

It will be observed, from the foregoing diagram, that the import balance was most pronounced during the decade which closed in 1913 . This was a period of heavy foreign borrowings on the part of Canadian governments, municipalities, and industry. The excess of imports in large part formed the offsetting factor to counterbalance this invisible credit in the form of foreign capital importation. With the partial depression of 1913-14, induced in part by the tightening of the European money markets, the economic energies of the Dominion were forced, as indicated elsewhere in this chapter, into the task of increasing production with the industrial plant already in hand, and for the time attention was diverted from the creation of new enterprises. 
Reduced import balances characterized the years 1914 and 1915. It is true the outbreak of the war contributed toward this result. In its later stages the war had the effect of stimulating production, practically eliminating unemployment, and creating a large overseas market for many Dominion products.

Yet the fact remains that quite apart from the war there was an important reason why readjustment was ultimately inevitable in the Dominion balance of trade. In discussing this phase of Canadian trade, The Monetary Times has declared that whereas the heavy foreign borrowings by Canada made possible the continuous import balance down to 1913 , the checking of such external loans in 1914 with their practical cessation in 1917 resulted in "corresponding effects on our trade." 1 Continuing, it added that "we now do most of our own financing, whereas we formerly did only a part. And the result has been that trade has been restored to more nearly normal; for it must be remembered that normal trade in the case of Canada will be represented by a very considerable balance in our favor, as we must export more goods than we import in order to pay the interest on our external obligations, and to gradually repay them as they fall due." The above contention that normal trade in the case of Canada must be marked by an excess of exports serves to support the opinion already expressed that the Do-

\footnotetext{
${ }^{1}$ The Monetary Times, January 3, 1919, p. 68.
} 
minion is about to become a mature borrowing country-a country whose annual interest obligations are soon to exceed in volume the new foreign capital that yearly may be imported.

Recalling the statement that English loans to Canada helped that country formerly to finance its trade with the United States, and bearing in mind the fact that during the war Canada was able less and less to borrow in the British market, we find ourselves facing the question as to the means recently employed by Canada for the purchase of imports from her American neighbor. That the pre-war balance of trade between Canada and the United States was not altered materially by the war may be noted from the following table in which figures are grouped by four-year periods. ${ }^{1}$

\begin{tabular}{|c|c|c|}
\hline $\begin{array}{c}\text { Year ended } \\
\text { March } \$ 1\end{array}$ & $\begin{array}{c}\text { Balance of Merchandise } \\
\text { Trade favorable to the } \\
\text { United States }\end{array}$ & $\begin{array}{l}\text { Balance of Trade favor- } \\
\text { able to the United States; } \\
\text { after making allowance } \\
\text { for shipments of gold }\end{array}$ \\
\hline $\begin{array}{l}1907-1910 \ldots \\
1911-1914 \ldots \\
1915-1918 \ldots\end{array}$ & $\begin{array}{r}\$ 398,000,000 \\
927,000,000 \\
1,050,000,000\end{array}$ & $\begin{array}{r}\$ 394,000,000 \\
926,000,000 \\
904,000,000\end{array}$ \\
\hline
\end{tabular}

But for the war, with its curtailment of Canadian borrowings in London, this balance would doubtless have been financed in the usual way. Subsequent to 1914 a change appeared in the source from which the Dominion obtained foreign capital. This fact and also the identity of the new source are revealed in the statement which follows.

${ }^{1}$ Rife, The Monetary Times, January 3, 1919, p. 158. 
Canadian Borrowings from Great Britain and the United STATES : $1912-1917^{1}$

\begin{tabular}{|c|c|c|c|}
\hline Year & $\begin{array}{l}\text { Canada's total } \\
\text { borrowing }\end{array}$ & $\begin{array}{c}\text { Per cent of } \\
\text { Canada's borrowa } \\
\text { ing in Great } \\
\text { Britain }\end{array}$ & $\begin{array}{c}\text { Per cent of } \\
\text { Canada's borrow } \\
\text { ing in the United } \\
\text { States }\end{array}$ \\
\hline $\begin{array}{l}1912 \ldots \ldots \\
1913 \\
1914 \\
1915 \\
1916 \\
1917\end{array} \ldots \ldots$ & $\begin{array}{r}\$ 272,900,000 \\
373,800,000 \\
272,900,000 \\
341,900,000 \\
316,900,000 \\
772,700,000\end{array}$ & $\begin{array}{c}74.8 \\
74.2 \\
68.1 \\
14.1 \\
1.5 \\
.63\end{array}$ & $\begin{array}{l}11.3 \\
13.5 \\
19.77 \\
72.11 \\
64.89 \\
24.06\end{array}$ \\
\hline
\end{tabular}

${ }^{1}$ Rife, The Monetary Times, January 3, 1919, p. 158.

American investments in Canada, which amounted to more than $\$ 600,000,000$ prior to the war, were more than doubled during the four years following 1914. Yet notwithstanding the large volume of United States capital imported into Canada during the war period, we can readily see that it was scarcely of itself sufficient to offset the vast trade debit balance against Canada on account of imports from the United States. We should perhaps expect, therefore, in our search for additional Canadian credits, that the Canadian excess of exports to Britain over imports from that country, which normally marked pre-war trade, would latterly have grown to much larger proportions. This, indeed, has been the case, as the appended figures show.

\begin{tabular}{c|c}
\hline Years ended March $\$ 1$ & $\begin{array}{c}\text { Anglo-Canadian trade } \\
\text { Merchandise balance in favor of Canada }\end{array}$ \\
\hline $1907-1910 \ldots \ldots \ldots \ldots \ldots$ & $\$ 166,000,000$ \\
$1911-1914 \ldots \ldots \ldots \ldots \ldots$ & $167,000,000$ \\
$1915-1918 \ldots \ldots \ldots \ldots \ldots$ & $1,870,000,000$ \\
\hline
\end{tabular}

${ }^{1}$ Rife, The Monetary Times, January 3, 1919, p. 158. 
Through her enormously increased purchases of Canadian goods during the war period, Great Britain seemingly has continued to contribute credits toward the financing of American imports into the Dominion. This end, which was served before 1914 by the Canadian importation of British capital, would appear since then to have been attained through greatly enlarged exports of Canadian merchandise to Britain. Moreover, we should expect to find in this great export balance of the Dominion the means whereby Canada would be enabled as well to meet her invisible debit of interest charges. But we discover that Canada was obliged to sell to the Mother Country chiefly on credit. The Dominion, therefore, has been "in the position of selling largely to a buyer who cannot pay cash, and of buying largely from a seller who demands cash terms." The inevitable result has been a sharp discount on Canadian funds in the American market.

It was stated in an earlier connection that foreign exchange operations are closely related to the movements of international trade. Canada naturally is vitally interested in the course of sterling and dollar exchange, with the United Kingdom and the United States respectively. It is to be noted that Canada's quotations for sterling exchange, and for francs, lire, marks, etc., are merely the New York quotations for these exchanges with an allowance for the existing premium or discount on American funds quoted in Montreal and Toronto. 
Thus on October 29, 1920, the rate for demand sterling bills in New York was about \$3.47, while in Toronto it stood at \$3.83. The Toronto quotation was higher to the extent of the premium on New York funds which at that time amounted to $109 / 10$ per cent.

In explaining the process by which innumerable transactions in foreign exchange, occurring daily in thousands of banks in the United States and Canada, lead to the adjustment of the rate of exchange, Mr. Stewart Patterson points out that "New York is the recognized foreign exchange market of the continent, and banks throughout the country having exchange to sell or buy do so through their New York correspondents." 1 Continuing, he adds that "some New York banks will have exchange to sell, others orders to buy, and the scarcity or abundance of the bills of exchange on any country is promptly disclosed by, competition, and the rates adjust themselves accordingly. Foreign exchange brokers, as they are called, act as intermediaries between buyers and sellers in New York. As the factors which regulate the supply and demand are constantly changing, the brokers must keep in close touch with the market and with their clients." The ruling rates in New York are daily telegraphed to Canadian banks and brokers, and these rates are made applicable to Canada after the discount or premium on New York funds has been taken into account.

${ }^{1}$ Stewart Patterson, "Domestic and Foreign Exchange," p. 43. 
Exchange is a commodity, and like any other commodity its value is subject to the laws of supply and demand. Thus, disregarding the invisible items for the moment, "if Canadian exports to the United States are equal to the exports of the United States to Canada, exchange will be at par. If Canadian exports are the larger, New York funds will be plentiful in Montreal, and will be quoted at a discount. If the imports exceed the exports, New York funds will be in demand in Montreal and the rate will be at a premium." Although, as stated elsewhere, the exports and imports of merchandise are the principal factors of international indebtedness, there are other important elements, the so-called invisible items, which influence the foreign exchanges and the balance of international payments.

Inasmuch as gold, under normal conditions, can be transferred between Montreal and New York for about 70 cents per $\$ 1000$, or approximately $5 / 64$ of 1 per cent on either side of par, it follows that a bank, as a rule, would bring gold to Canada as soon as a rate of $5 / 64$ per cent discount was quoted, or ship gold to New York when 5/64 per cent premium was reached. Before the war New York funds in Canada (in other words, the price of American exchange) fluctuated so little, having a range of only about $1 / 8$ of 1 per cent between the gold points, that the banks as a rule charged a flat rate irrespective of market conditions on all but the large transactions. It is perhaps true that the 
public generally did not look upon New York funds as foreign exchange. The charge made by a bank when negotiating a check on New York came, more or less generally, to be looked upon as a bank commission. As a consequence there are still some who persist in regarding the price paid for New York funds as a bank commission, or charge for service. Since 1914, the price of American exchange has fluctuated widely, ranging from about $11 / 4$ per cent discount to $191 / 4$ per cent premium. This variation, made possible largely by the practical elimination of free gold shipments between the two countries with their steadying influence, has led the banks to abandon the flat rate and to allow or charge their customers a premium or discount as the case may be.

The relation, prior to 1914, between the balance of trade and the foreign exchange rates in the case of Canada and her neighbor to the south has been concisely set forth by Mr. Stewart Patterson in the Journal of the Canadian Bankers' Association:

"Until 1912, New York funds in Canada were generally at a discount," he reminds us, "averaging between $1 / 64$ to $1 / 32$ of 1 per cent, and this in the face of the fact that the so-called 'balance of trade' was always against Canada. In other words, imports from the United States greatly exceeded Canadian exports to the United States by some $\$ 250,000,000$ a year, and yet the rate of exchange was generally in favor of Canada. This anomalous condition was due principally to the steady flow of British and foreign capital into 
Canada during the period referred to, the relative exchange operations being effected through New York. With the diminution of the volume of these investments, and the constantly increasing remittances to Europe on account of dividends, interest, etc., the position gradually reversed, and between 1912 and 1914 the tendency of the market for New York funds has been more or less against Canada, the average working out at par or a slight premium." 1

During the later years of the war Britain's ability to pay cash for Canadian products was severely restricted, and as Canada's sales of new securities in the British market were largely discontinued, it was no longer possible to sell sterling exchange in New York in sufficient quantity to provide for the balances due to the United States on trade account. It was possible, it is true, for a time to sell in the American market securities which formerly would have been taken by England, and so long as this state of affairs prevailed the credits thus created in New York largely sufficed to enable Canada to finance her excess purchases of American merchandise. But even these sales of Canadian securities suffered a reduction in 1917, when the United States entered the war. In the meantime, the Canadian merchandise trade balance came to be marked by a large excess of exports. So large was this so-called favorable balance in Canada's trade with the world at large that her

'Stewart Patterson, "New York Exchange in Canada," The Journal of Canadian Bankers' Association, April, 1918. 
unfavorable balance with the United States would seem to have been much more than counterbalanced. Under normal circumstances this would have been so, and Canada would have had a large amount of sterling and other exchange to dispose of in New York. The net balance due Canada, after meeting her adverse merchandise balance with the United States, would have had the effect of depressing in the Dominion the rate of American exchange.

But, as has been stated above, a large part of this favorable balance of the Dominion represented exports sold to Britain and other Allies on a time basis. The trade credits which were thus created in her favor, Canada was unable at once to utilize in liquidating the balances due the United States. Moreover, it was not possible to fall back upon gold shipments to make settlement. As a result a sharp competition arose in Canada for New York funds with which to pay American exporters and other creditors in the United States. That the demand for such funds has been very vigorous is at once revealed by the course of American exchange. The chart below shows the fluctuations in the cost of New York exchange in Montreal during the ten years from 1910 to 1919 . The movement is expressed, it will be noted, in premium or discount in dollars per $\$ 1000$, and not in percentages.

The narrow limits within which exchange fluctuated prior to 1914 are indicated in the following diagram. The height reached by New York ex- 
change during the last months of 1919 was, however, exceeded during the following year. This fact appears in the graph which follows. The value of the American dollar in Canada is shown on page Fluctuations from Par of New York Exchange in Montreal ${ }^{1}$

(Premium or Discount per $\$ 1,000$.)

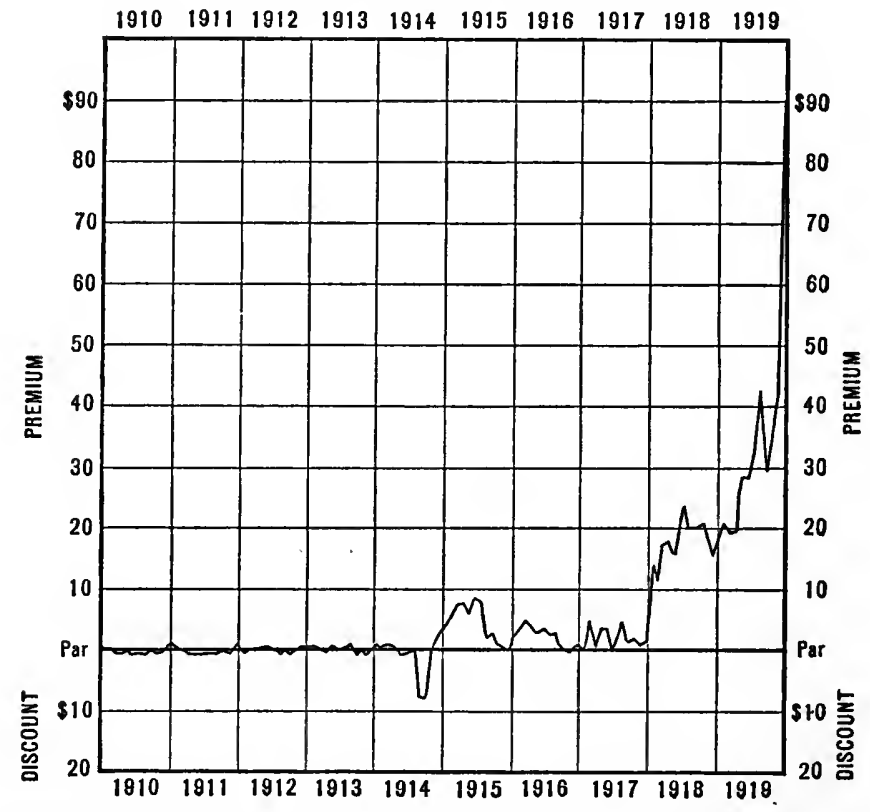

147 for the period from January, 1917, to April, 1921. In this instance, the fluctuations are expressed on a percentage basis. Moreover, the highest and lowest values for each month are recorded, whereas in the preceding case the average rate only was depicted.

${ }^{1}$ The Monetary Times, January 9, 1920, p. 46. 
THE CANADIAN BALANCE OF TRADE 147

Although, as has already been stated, Canadian quotations of sterling exchange represent sterling quotations in New York plus or minus the premium

Mon'thly Variation of Value of the American Dollar in CANAda. ${ }^{1}$ JANUARY, 1917-APriL, 1921

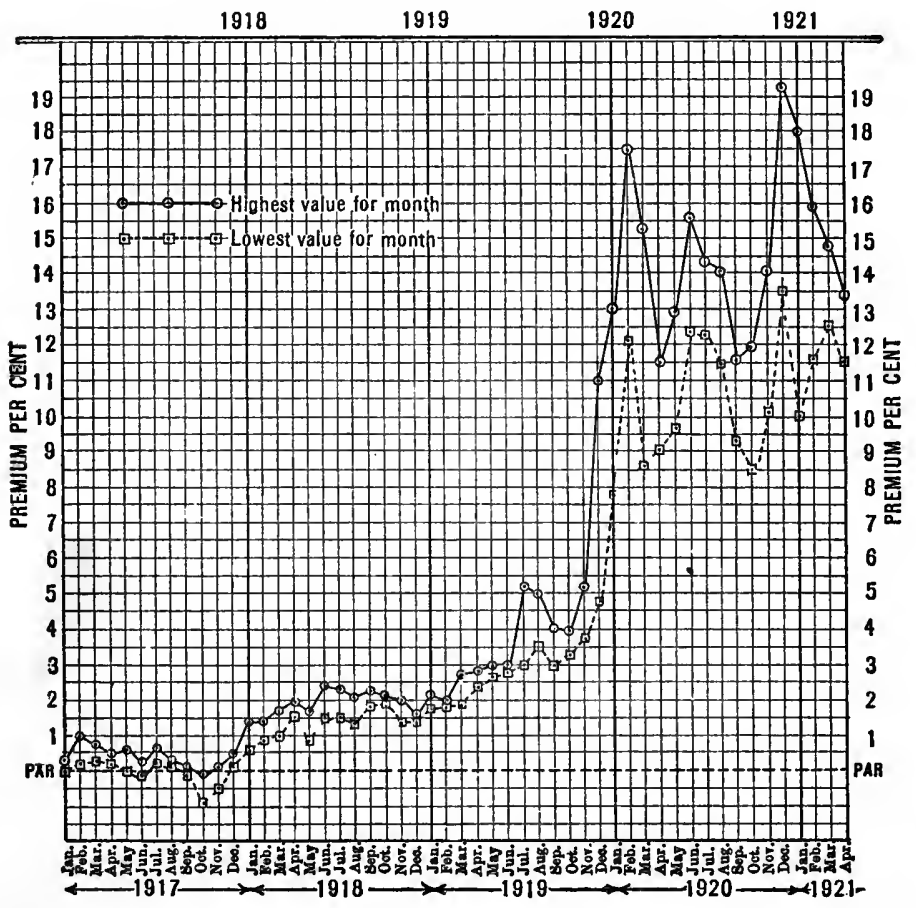

or discount existent at the time on American funds in the Dominion, the course of sterling exchange and that of New York exchange naturally do not

${ }^{1}$ Weekly Bulletin, Department of Trade and Commerce, Ottawa, May 30, 1921, p. 861. 
run parallel to one another at all times. In the diagram which follows, a picture is presented of the fluctuations in Montreal of both sterling and dollar

Fluctuations of Sterling Ratels and of the Premium on United States Funds ${ }^{1}$

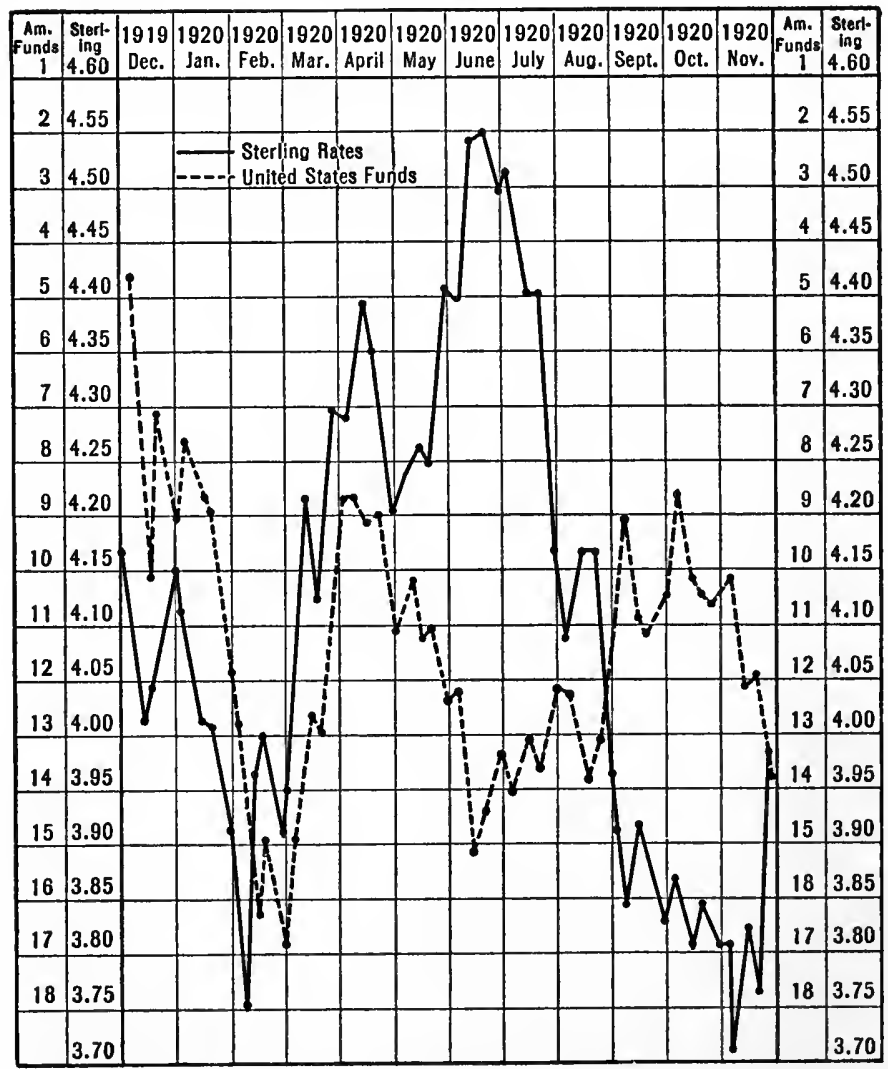

${ }^{1}$ Monthly Letter of Royal Bank of Canada, January, 1921. 
exchange during the twelve months ended November 30,1920 . The graph is constructed upon the basis of four quotations each month of both sterling rates and the premium on American funds. They comprised the high and low records for every fortnight. During the early months of the period the two exchanges appeared to move more or less in sympathy with one another. With a decline in sterling, the premium on the American dollar increased, and vice versa. Later, this no longer appeared to be the case. During the latter part of August, September, and October the price of sterling fell rapidly, a decline also appearing in the premium on New York funds. Both conditions were to be attributed to the same cause-wheat. At that season Canada was selling wheat, and England was buying.

It is of course obvious that when New York exchange is at a premium in Canada, Canadian funds are at a discount in New York. In consequence of the depreciation which Canadian exchange has suffered in the New York market, the position of the Canadian buyer of American goods is not a favorable one. Yet, his position is probably much better than that of many others. At the present time Canadian exchange is less depreciated in New York than that of most other commercial countries. The exchange rates on the principal commercial nations, as quoted in New York on June 27, 1921, were as follows: 
RATE IN Cents

\begin{tabular}{|c|c|c|c|}
\hline & Normal & June 27 & $\begin{array}{l}\text { Per cent of } \\
\text { Depreciation }\end{array}$ \\
\hline 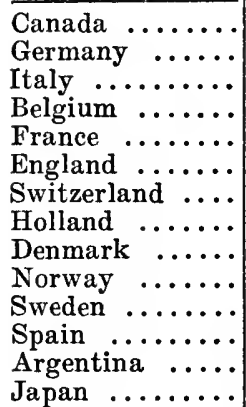 & $\begin{array}{l}\$ 1.00 \\
.2382 \\
.1930 \\
.1930 \\
.1930 \\
4.8665 \\
.1930 \\
.4020 \\
.2680 \\
.2680 \\
.2680 \\
.1930 \\
.9648 \\
.4985\end{array}$ & $\begin{array}{l}.8825 \\
.0135 \\
.0595 \\
.0805 \\
.0807 \\
3.76 \\
.17 \\
.3315 \\
.1705 \\
.1450 \\
.2245 \\
.1320 \\
.6850 \\
.48\end{array}$ & $\begin{array}{l}113 / 4 \\
941 / 4 \\
69 \\
58 \\
58 \\
223 / 4 \\
12 \\
171 / 2 \\
361 / 2 \\
46 \\
161 / 4 \\
311 / 2 \\
29 \\
37 / 8\end{array}$ \\
\hline
\end{tabular}

The discount on Canadian funds in the United States has the effect of increasing the price, in Canadian currency, of American goods to the Canadian purchaser. The apparent hardship thus imposed upon the Canadian importer carries with it, however, an apparent advantage to some fellow citizens of his. The Canadian importer who is obliged to buy New York funds with which to pay for his American purchases does not procure those funds from an American dealer. Instead he buys the necessary New York funds, or more accurately the right to funds in New York, from a Canadian in possession of such a right. To be sure, the interchange between the two is normally effected through the banks. The essential fact, however, remains that he who normally provides the supply of exchange which the importer is obliged to buy is not an American, but instead the Canadian who 
may have New York funds for sale, one exporting to the United States it may be. Thus the American exporter of goods to Canada receives merely the face amount of the invoice. The cost to the importer in Canada represents the American price, plus the exchange premium, plus customs duty and transportation charges. On the other hand, the cost of Canadian goods to the American importer represents the Canadian price, plus transportation charges and duty, but minus exchange.

Considerable ambiguity is occasioned by the fact that the term dollar is alike applied to the monetary unit of both Canada and the United States. While the two are normally of equal value, the Canadian dollar at present (June, 1921) has a value not quite ninety per cent of that of the American unit. There is a difference in the general level of prices in the two countries, which probably approximates roughly the discount on the Canadian dollar. The depreciation of the Canadian currency is the explanation fundamentally of both the discount of the Canadian dollar in the United States and the disparity in prices between the two countries.

Contrary to a view sometimes expressed, the banks of the country are not to be held responsible for the discount on Canadian funds in the United States. The situation has not been brought on by some hidden and sinister manipulation by the banks. In exchange transactions the bank charges a commission, whether the rate be at par 
or far removed from it. "To the banker the situation is a nuisance," we are assured. "He makes no more in selling a draft now than he would under normal conditions, frequently not so much." Nor is the depreciation of the Canadian dollar in the American market to be regarded as evidence of commercial selfishness on the part of the United States. Instead, the exchange rate should be looked upon as a gauge automatically registering changes in the volume and character of international transactions of a commercial and financial nature.

The function of the foreign exchanges may be likened to that of the thermometer. The latter measures the temperature. "It does not create it," we are reminded by Mr. F. A. Vanderlip, "and stoking the furnace is obviously the thing that must be done rather than to spend time grumbling about the thermometer. Just so with the exchanges. The quotation of exchange registers the direction and the extent by which the total importations and exportations of a country are out of balance. It is no more a matter that can be corrected by bankers, who happen to be the men who hold the visible gauge that marks the fluctuations of the exchanges, than the temperature could be regulated by some attempt to control the movements of the mercury in the bulb of the thermometer by other means than altering the general temperature that surrounds that instrument." 1 A

'Vanderlip, "What Happened to Europe," p. 91. 
further analogy appears in the case of a pair of scales. If one scale-pan is more heavily weighted than the other, at once the scale indicator or pointer reflects the fact that the balance is not at equilibrium. The pointer, however, is not to blame that the scales are out of balance. Likewise the exchange rate, the pointer in the field of foreign exchange, is not at fault if exchange is at a premium or a discount. The correction must be made by varying the weights in the scale-pans, the total credits and debits of the country.

It has already been stated, in another connection, that the course of trade is influenced by the fluctuations in exchange rates. A stimulating or depressing effect, as the case may be, is felt by exports and imports in response to such variations, which must be taken in conjunction, however, with other factors, notably changing price levels and the condition of the currency. Too often the influence exerted by these additional factors is disregarded. For example, it is asserted, without reference to the qualifying conditions, that the movement of exchange has the effect of increasing or decreasing the measure of protection present in the customs tariff. It is asserted that when foreign exchange is at a premium it necessarily operates as an increase in the customs rates, thus discouraging imports. With a premium in Canada of twelve per cent on American exchange the result must be, it is declared, increased protection against American goods. And in England, France, Italy, and other 
countries where the premium on New York exchange is still higher, the importation of American goods is subject to a correspondingly greater discouragement. Conversely, a premium on exchange is said to affect exports in the opposite fashion. As a result of the exchange situation between Canada and the United States, the duties in the American tariff must be rendered less effective against exports from Canada. Similarly, the premium in Great Britain on Canadian exchange would have the effect of stimulating British exports to the Dominion and hampering British imports therefrom.

The case, however, is not so simple. In some instances the premium on foreign exchange has the effect outlined above, in some cases its effect is more than neutralized by the other factors to which reference has been made, so that the total effect is exactly the reverse. An illustration will perhaps suffice to make this clear. During the year 1919, French exchange was subject to a depreciation of fifteen to forty-five per cent. French francs sold in Paris at six or seven to the dollar as compared with 5.18 to the dollar on the basis of par. In consequence of this premium on American exchange, averaging perhaps twenty-five per cent, the importation of American goods into France, according to the views outlined above, must have suffered discouragement. And this must have been so for the reason that the French franc, in a condition of depreciation, would purchase less of American goods than under normal conditions. 
But meantime prices in France were three times as high as they were before 1914. Under these conditions it naturally was profitable to export goods from the United States to France. By the same token, the French importer of American goods was greatly stimulated to increase his purchases. The fear became general that goods from the United States would flood France to the injury of the domestic industries. For a time, as a consequence, the French Government maintained the war prohibitions on imports. Since 1919 the situation in France in respect of exchange and prices has been largely reversed.

A premium on exchange may, therefore, have an influence in either direction, as has been pointed out elsewhere at greater length. ${ }^{1}$ If the premium on foreign exchange has risen higher than the general level of prices, exports will be stimulated, if it has risen less, imports will be stimulated. If a state of equilibrium has been reached between prices and the rate of foreign exchange, there will be no artificial stimulus on either exports or imports. This so-called equilibrium, as stated elsewhere, is attained when the increase of prices corresponds with the increase in foreign exchange rates (i. e., with the increase in the price of gold).

On account of the wide fluctuations in the rates of exchange and their possible effects, stimulating or otherwise, upon the course of trade, customs

${ }^{1}$ This question has received more extended treatment in Chapter $\mathrm{I}$. 
regulations in various countries have been amended to meet the situation. Formerly the value of imported goods in foreign currency was converted into terms of Canadian dollars at the gold par rate of exchange, and customs duties were assessed in accordance therewith. This practice continued for a considerable time, notwithstanding the extraordinary deviation of the exchange rates from par. This meant, for example, that goods from France valued in the currency of that country at 100 francs would be assessed for duty on the basis of a value of $\$ 19.30$, while at the time 100 francs might actually be worth no more than $\$ 8$. England was the country principally affected, inasmuch as Canada imports a much larger volume of goods from Britain than from any other country whose money is at a discount in the Dominion. The customs law was amended in the spring of 1920 to allow the conversion of depreciated currencies at the current rates of exchange. By a further change in the act, to which assent was given on June 4, 1921, it was provided that appreciated currencies should be treated in the same fashion. The one important currency standing at a premium in Canada is that of the United States. But since seventy per cent approximately of Canadian imports come from that country the change is of some moment. If thirty per cent be taken as the average duty in the Canadian tariff on manufactured goods, and if ten per cent be regarded as the average premium on American money, the new pro- 
vision has the same effect as an increased duty of three per cent on the old basis of valuation. This statement does not imply the presence of a bounty or of an obstruction upon the movement of exports. The two questions though related are quite distinct. This form of increased protection will doubtless continue until Canadian currency is once more on a par with that of the United States.

The customs amendment of 1921 provides also that, for the purpose of computing customs duty, the value of goods shall in no case be less than the cost of production and a reasonable profit thereon, and that the currency in which the goods are invoiced shall not be valued at less than fifty per cent of the standard of the country to which it belongs. This provision doubtless is directed mainly against countries such as Germany, in which the currency depreciation, as reflected in the price level, has not kept pace with the depreciation of the currency in foreign exchange. Thus the depreciation of the German mark in the exchanges has not yet been fully reflected in higher production costs at home.

To remedy the adverse rate of exchange with the United States various suggestions have been offered. It has been urged that exports be enlarged through increased production, and that imports be diminished by curtailing the importation of socalled nonessential articles and of goods which can be produced in the Dominion. Canadians have also been urged to insure with Canadian companies, on the ground that the premiums annually remitted 
abroad to foreign life and fire insurance companies affect the exchange rate adversely.

It is stated further that what the people of the Dominion obviously need is to reduce their purchases from the United States and to increase them from Great Britain and the other countries which owe gold to the Dominion, and which will thereby be better enabled to make payment in goods. The present state of the exchanges is doubtless helping gradually to bring these things to pass. The exchanges in Canada appear alike to place a penalty on purchases from the United States and a premium on purchases from Great Britain. However, because of the production difficulties in Britain and the firm hold which, thanks to proximity and similar tastes and habits, the American producer has on the Canadian market, this process of readjustment will not be a rapid one. It will naturally be accelerated by Canadian loans floated in the United States and by the sale of securities to American investors. 


\section{CHAPTER V}

\section{THE INDIAN TRADE BALANCE}

In India the balance of trade in the past stood out in contrast to that of Canada. Whereas the pre-war trade balance of the Dominion was marked by an excess of imports, that of India was characterized by an export balance. To heighten the contrast it may be noted that, while the Canadian excess of imports was growing more pronounced during the two decades preceding the war, in India, on the other hand, there was a general increase in the excess of exports during the same period.

India has already been called a mature borrowing country. That she has been in this position for some time may be seen from the table which follows.

Balance of Trade of India ${ }^{1}$

(Figures denote $\mathfrak{£}$ millions)

\begin{tabular}{c|c|c|c|c}
\hline & \multicolumn{2}{|c|}{ Average of 5 years ending } & One year \\
& $1883-84$ & $1893-94$ & $1903-04$ & \\
$1913-14$ \\
\hline $\begin{array}{l}\text { Net excess of exports in } \\
\text { cluding mer chandise, } \\
\text { treasure, and enfaced } \\
\text { rupee paper .......... }\end{array}$ & 13.9 & 14.9 & 19.9 & 23.1 \\
\hline
\end{tabular}

1 "Review of Trade of India in 1914-15" (Cd. 8228), p. 120. 
From the foregoing statement we note that India, before the war, had a so-called favorable merchandise balance which amounted to about $\$ 100$,000,000 a year. Before attempting an estimate of the balance of India's invisible factors, let us take account of the various items which go to make up the balance of her international debits and credits. They are as follows:

1. Merchandise imports and exports.

2. Payments to foreign shipping interests. As is well known, India is forced to meet heavy charges on account of the transportation of her goods in foreign bottoms, since there are few India-owned steamships. Inasmuch, however, as these charges are for the most part included in the declared figures for imports, it is to that extent unnecessary to make any further allowance for them. After making reasonable adjustments between shipping debits against India and certain credits in favor of that country on account of port and pilotage dues, cost of coal and stores purchased in India, wages of the crew spent in India, etc., it is probable that the net result is a minor debit against the country of not less than $£ 33,000$, over and above the amount for freight actually included in the values recorded for imports. ${ }^{1}$

3. Investments of foreign capital in India and the payment of interest charges by India.

4. Other debits against India include various miscellaneous charges for the use of foreign capital

' Report for 1913-14 of Controller of Currency for India, p. 55. 
or credit, by way of commission, premiums of insurance, and remittances to England on private acconnt, as for example on behalf of Indians residing in England.

5. On the other side will occur a corresponding credit to India on account of income remittances from England (or elsewhere abroad) to persons resident in India, such as British officers in enjoyment of independent incomes.

6. Private remittances of securities. The effect of this item is similar to that of number three.

7. Private imports and exports of the precious metals. In striking the balance of accounts, these should be treated as imports and exports of other commodities on private account. It is true the importation of the precious metals has been largely controlled by the Government since 1917.

8. The transactions of the Indian Government, whether in the form of loans, remittances of interest, pensions, imports and exports of the precious metals or of other commodities. ${ }^{1}$

In somewhat condensed form the following table presents the chief items of the foreign trade (i. e., the visible exports and imports) of India for a series of years. ${ }^{2}$

${ }^{1}$ No account will be taken in this study of the large war-contributions of capital made to Britain by India and raised largely in India.

2 "Statement of Moral and Material Progress and Condition of India for 1911-12," p. 286. 
(Figures denote $\mathfrak{f}$ millions)

\begin{tabular}{|c|c|c|c|c|c|}
\hline & $|1905-06|$ & | $1907-08$ & $\mid 1909-10$ & $\mid 1910-11$ & $1911-12$ \\
\hline $\begin{array}{l}\text { Imports: } \\
\text { Private Merchandise } \\
\text { Government Stores.. }\end{array}$ & $\begin{array}{r}68.7 \\
6.0\end{array}$ & $\begin{array}{r}86.6 \\
4.4\end{array}$ & $\begin{array}{r}78.0 \\
3.7\end{array}$ & $\begin{array}{r}86.2 \\
2.9\end{array}$ & $\begin{array}{r}92.4 \\
3.6\end{array}$ \\
\hline Total $\ldots . . \ldots \ldots$ & 74.7 & 91.1 & 81.7 & 89.1 & 96.0 \\
\hline $\begin{array}{l}\text { Exports: } \\
\text { Private Merchandise. }\end{array}$ & 107.9 & 118.3 & 125.3 & 139.9 & 152.0 \\
\hline $\begin{array}{c}\text { Net Exports of } \mathrm{Mer}- \\
\text { chandise } \ldots \ldots \ldots \ldots\end{array}$ & 33.2 & 27.2 & 43.6 & 50.8 & 56.0 \\
\hline $\begin{array}{l}\text { Imports of Treasure.. } \\
\text { Exports of Treasure.. }\end{array}$ & $\begin{array}{l}21.1 \\
10.3\end{array}$ & $\begin{array}{r}28.2 \\
3.6\end{array}$ & $\begin{array}{r}25.0 \\
4.3\end{array}$ & $\begin{array}{r}26.5 \\
4.8\end{array}$ & $\begin{array}{r}35.6 \\
6.9\end{array}$ \\
\hline $\begin{array}{c}\text { Net Imports of Treas- } \\
\text { ure } \ldots \ldots \ldots \ldots \ldots \ldots\end{array}$ & 10.8 & 24.6 & 20.7 & 21.7 & 28.7 \\
\hline $\begin{array}{l}\text { Net Excess of Exports, } \\
\text { including Merchan- } \\
\text { dise and Treasure... }\end{array}$ & 22.4 & 2.6 & 22.9 & 29.1 & 27.3 \\
\hline
\end{tabular}

Including government stores: a very small item, in no year exceeding $£ 100,000$.

After taking into consideration all debit and credit transactions (the invisible as well as the visible), there is customarily a small net balance in favor of India. Occasionally, however, an adverse balance is confronted. For example, during the fiscal year 1907-08 there resulted a net debit against India. It was attributed to a famine in India, a credit crisis in the United States, and other unfavorable conditions. Again, during 1913-14 an adverse balance appeared. In that year, although gross merchandise exports were slightly larger than ever before, the volume of gross merchandise imports was so much larger than in any preceding 
year that the excess of merchandise exports was the smallest in five years, as noted in the following table. ${ }^{1}$ In contrast to the previous tabulation, no account here is taken of government stores, railway equipment, and the precious metals.

(Figures denote $\mathfrak{£}$ millions)

\begin{tabular}{c|c|c|c|c|c}
\hline & $1909-10$ & $1910-11$ & $1911-12$ & $1912-13$ & $1913-14$ \\
\hline $\begin{array}{c}\text { Gross Exports of Pri- } \\
\text { vate Merchandise ... }\end{array}$ & 125.3 & 139.9 & 152.0 & 164.1 & 165.9 \\
$\begin{array}{c}\text { Gross Imports of Pri- } \\
\text { vate Merch andise } \\
\text { (less railway plant }\end{array}$ & & & & & \\
and rolling stock) .. & 74.4 & 83.3 & 89.7 & 103.0 & 115.5 \\
\hline $\begin{array}{l}\text { Net Export of Private } \\
\text { Merchandise ....... }\end{array}$ & 50.9 & 56.6 & 62.3 & 61.1 & 50.4 \\
\hline
\end{tabular}

In this statement, no provision is made for the large quantity of railway material imported into India. In the painstaking Report for 1913-14 of the Controller of Currency for India, it is stated that the imports into India of railway plant and rolling stock during the fifteen years from 18991900 to $1913-14$ inclusive were valued at $\mathfrak{£} 75$ millions. Of this amount, however, nearly $£ 60$ millions were paid for by capital raised in England either by the Government of India or by railway companies. The balance was met by government remittances from India. Obviously it would be misleading, therefore, as pointed out in that Report, in making up India's international account, to debit her, as is often done, with the imports of railway ${ }^{1}$ Report for 1913-14 of the Controller of Currency for India, p. 51. 
material, unless there be entered as corresponding credits $(a)$ the net capital raised in Great Britain to purchase the material and $(b)$ the export of funds from India in the form of government remittances, to the extent to which these are applied to capital outlay. After making the necessary adjustments to meet this condition, after making provision for such credit items as foreign loans contracted by industrial companies and the so-called "port-trusts," and after taking account of such debit items as interest charges on foreign loans, private remittances abroad, the importation of bullion, etc., the Report presents a net balance sheet for India for a series of years. The results may be epitomized as follows : ${ }^{1}$

(Figures denote $£$ millions)

\begin{tabular}{|c|c|c|c|c|c|c|c|}
\hline & 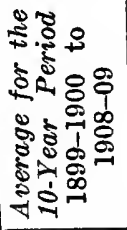 & 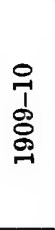 & 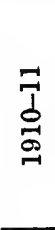 & 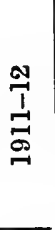 & 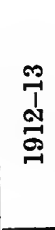 & 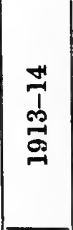 & 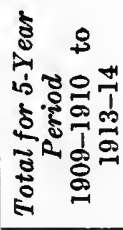 \\
\hline $\begin{array}{l}\text { The net or "unex- } \\
\text { plained" balance. }\end{array}$ & 0.5 & 2.2 & 5.2 & 3.1 & 2.0 & $6.0^{*}$ & 6.3 \\
\hline
\end{tabular}

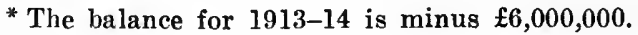

It is admitted that many of the figures in this balance sheet, although based on the most reliable available data, are estimates only. The abnormal balance for the year 1913-14 was due, probably, to

${ }^{3}$ Report for 1913-14 of the Controller of Currency for India, p. 52 . 
certain unusual circumstances. Owing to the large accumulations in China of opium exported by Indian merchants, the price of opium did not enable them to realize in full on such exportation, with the result that this credit to India was being met gradually and therefore was partly extended over into the succeeding year. It is believed also that the exchange banks in India strengthened their balances during this year. Furthermore, it is probable that the imports of capital into India in the form of mill machinery, railway rolling stock, and the like, were larger than usual, or else (and this would have the same effect) that some portion of the profits of existing companies were retained in India for the same purpose.

The degree to which India has been dependent in the past on foreign capital for her productive enterprises can scarcely be exaggerated. The total capital outlay on railways to the end of the fiscal year $1913-14$ was $£ 369,265,000$ (about $\$ 1,800,000$, 000). ${ }^{1}$ On irrigation projects, the other chief branch of public works, the capital expenditure to the end of the year 1912-13 amounted to $£ 43,442,253$ (about $\$ 215,000,000) .{ }^{2}$ The United Kingdom owns and subscribes the great bulk of the foreign issues of Indian securities. That this is so may be inferred from a condensed statement of the debt of India. The total debt is classified in the accounts

${ }^{1}$ Report for 1913-14 of Railway Department, vol. II, p. 271.

2 "Statement of Moral and Material Progress and Condition of India for 1912-13," p. 77. 
as (1) Public Works Debt and (2) Ordinary Debt. The amount entered as belonging to the former category is the equivalent of the capital expenditure which has been incurred by the State on public works, together with the amount advanced to railway companies for disbursement; the "Ordinary Debt" consists of the remainder. The classification of the debt outstanding on March 31, 1913, follows: ${ }^{1}$

(Figures denote $\mathfrak{f}$ millions)

(a) Public Works Debt:-

Debt for railways $\ldots \ldots \ldots \ldots \ldots \ldots \ldots \ldots \ldots \ldots \ldots \ldots \ldots \ldots$

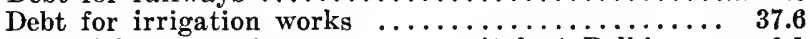

For initial expenditure on new capital at Delhi .... 0.1

Total of Public Works Debt .............

(b) Ordinary Debt (the balance) $\ldots \ldots \ldots \ldots \ldots \ldots \ldots \ldots \ldots .24 .9$

Total permanent debt, March $31,1913 \ldots \ldots \ldots \ldots \overline{£ 274.4}$

Of this total indebtedness, $£ 179$ millions was held in England, while the remainder, $£ 95$ millions, was held in India.

That the relation between Indian exports and imports must be affected by the continued practice of borrowing abroad is obvious. In large measure the loans secured by India in England for railway development, irrigation, etc., have taken the form of imports into India of railway rolling stock and other equipment. In 1911-12, for example, the capital outlay on railways, irrigation, etc., was $£ 9,501,700$, of which $£ 5,082,700$ was spent in England and $£ 4,419,000$ in India. The following table will further illustrate the past relationship ex-

1 "Statement of Moral and Material Progress and Condition of India for 1912-13," p. 20. 
istent between capital investments and imports of materials. ${ }^{1}$

\begin{tabular}{|c|c|c|c|c|}
\hline \multirow{2}{*}{\multicolumn{2}{|c|}{ Year }} & \multirow{2}{*}{$\begin{array}{l}\text { Indian Railway } \\
\text { Company Issues } \\
\text { in London }\end{array}$} & \multicolumn{2}{|c|}{$\begin{array}{c}\text { Imports of Railuay Plant and } \\
\text { Rolling Stock }\end{array}$} \\
\hline & & & From & $\begin{array}{l}\text { From } \\
\text { Elsewhere }\end{array}$ \\
\hline $\begin{array}{l}1907-08 \\
1908-09 \\
1909-10 \\
1910-11\end{array}$ & $\begin{array}{l}\cdots \\
\cdots \\
\cdots \\
\cdots\end{array}$ & $\begin{array}{r}\mathfrak{£} 2,200,000 \\
6,894,200 \\
3,183,900 \\
3,100,000\end{array}$ & $\begin{array}{r}£ 4,656,597 \\
4,745,709 \\
3,251,473 \\
2,528,984\end{array}$ & $\begin{array}{r}£ 143,953 \\
200,891 \\
375,591 \\
301,237\end{array}$ \\
\hline
\end{tabular}

It has been pointed out elsewhere that the effect of borrowing capital abroad is to swell merchandise imports, while, on the other hand, the interest charges on such capital will tend to augment the exports of the borrowing country. Therefore the customary excess of merchandise exports of India would lead one to expect to find a probable excess of invisible debits (such as interest charges, remittances, etc.) over imports of capital. An attempt will be made to apply this principle to conditions within the quite typical year 1911-12. The amount of new capital loaned annually to India is included under two main heads, namely, that invested in public works and that loaned for purposes exclusive of such enterprises. The total capital expenditure on railways in India had not prior to 1914 exceeded $£ 12,500,000$ in any one year, nor had the amount expended on irrigation surpassed

${ }^{1}$ Report of Royal Commission on Indian Currency, vol. I (Cd. 7070), quoted by Hobson, "The Export of Capital," p. 10. 
$£ 2,500,000$ within any twelve month period. ${ }^{1}$ And a large portion of the joint outlay on public works does not involve foreign loans, inasmuch as a considerable part of the expense is met from income. The new capital loaned to India, for other than railway and irrigation purposes, has been estimated to have been on the average between $£ 2$,000,000 and $£ 3,000,000$ a year, during the fifteen years preceding the war. ${ }^{2}$ It must be recalled that a large part of India's foreign loans enter the country in the form of railway and mill equipment and as such it is counted in merchandise imports. Therefore the amount of net capital flowing into India annually is much reduced.

The average annual capital subscription in Great Britain, during the fifteen years ended in 1914 , for Indian railways, less the value of imports of railway equipment, will represent the net capital raised in England for Indian transportation facilities. For the period in question the average net capital for this purpose is estimated at a little less than $£ 4,000,000$ per year. ${ }^{3}$ Applying the same correction in the case of loans for irrigation, industrial plants, etc., it is found that the net capital raised in England on account of India for these purposes probably did not exceed on the average much over $£ 1,000,000$ a year. The total of net

1 "Statement of Moral and Material Progress and Condition of India, for 1912-13," pp. 312-317.

${ }^{3}$ Report for 1913-14 of Controller of Currency of India, p. 53.

Ibid., p. 49. 
capital imports, therefore, amounted annually to about $£ 5,000,000$.

That the total of outflowing interest charges and other debits is much larger is apparent from the following table of Home Charges of the Government of India. ${ }^{1}$

\section{YEAR 1911-1912}

Interest and management of debt, and payment of interest, etc., on account of railways and irrigation works ...................... $10 \ldots, 768,754$ Payments in connection with Civil Departments in India

India Office (excluding pensions) $\ldots \ldots \ldots \ldots \ldots \ldots . \quad 184,870$

Army and Marine effective charges ........... 1,016,597

Stores of all kinds charged against revenue ...... 1,191,371 Furlough allowances .................... 98.968

Non-effective charges (pensions and gratuities) $\ldots .44,481,129$

Total

$£ 18,865,246$

Undoubtedly private remittances from India considerably augmented this total. It may be shown that such payments amounted roughly to about $£ 6,000,000$. In the first place, it has been estimated by Indian exchange banks that net private remittances from India amount to about $£ 2,000,000$ per year; there are also certain railway remittances which do not pass through the government account and which are believed to reach a figure of somewhat over $£ 500,000$; in this category also must be placed interest payable on foreign capital invested in industry and agriculture, which amounts to about $£ 2,500,000$ per annum. Certain minor factors, such as the payment to 1 "Statement of Moral and Material Progress and Condition of India for 1912-13," p. 161. 
foreign shipping companies, may be assumed to account for an additional outflow of not less than $£ 500,000$. Therefore, the total of invisible debits against India, including both the government charges and private remittances, may be placed at about $£ 25,000,000$. From this must be deducted the invisible credit, in the form of annual imports of net capital, which we have seen to be about $£ 5,000,000$. The resulting excess of invisible debits (i. e., interest charges, etc., over and above the inflow of net capital) for the year 1911-12 is, therefore, estimated to have been $£ 20,000,000$ or over.

It will be recalled from earlier figures that the net exports of merchandise, including treasure, for the year 1911-12 amounted to $£ 27,223,901$. This credit balance served as the offsetting factor counterbalancing the debit balance on account of the invisible items, which amounted, according to the

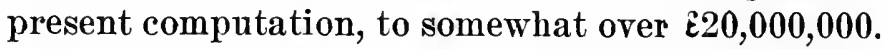
The disparity between these amounts is doubtless largely the outcome of over-conservative estimates where definite statistics are not available.

With ever increasing investments of foreign capital in India and the accompanying growth of interest charges, a continuing and increasing excess of merchandise exports may normally be expected to prevail. During the past thirty years, as already suggested, this tendency has manifested itself. Exports have grown more rapidly, in the main, than imports. This fact is revealed in the chart which follows. 


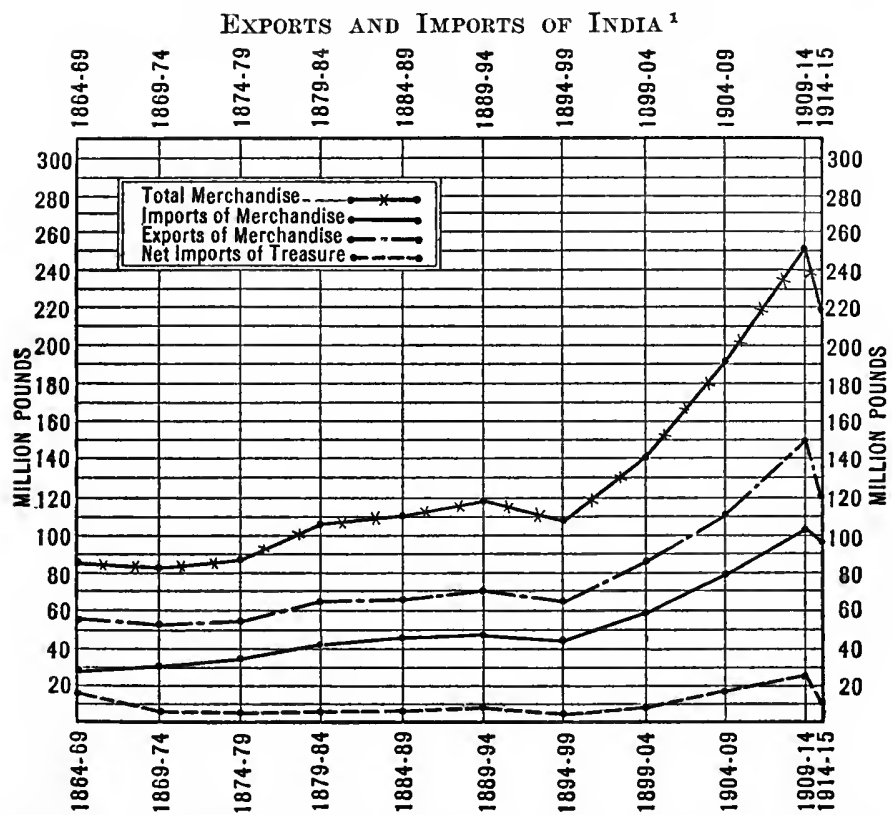

${ }^{2} 1$-Total Merchandise includes imports and exports, both private and government. 2-Imports of Merchandise are inclusive of government stores. 3-Exports of Merchandise are inclusive of re-exports and government stores. 4-Net Imports of Treasure are the imports minus the exports of Gold and Silver, both private and government.

The argument that the excess of merchandise exports of India represents an economic loss deserves but scant attention. The redundant merchandise exports are the logical result of India's excess of invisible debits. The latter excess in turn, as already mentioned, is to be attributed to heavy interest charges on foreign capital investments and to political expenses incident to the government of India. The investment of foreign capital has made possible for India the construction of 35,000 miles of railways, thousands of 
miles of irrigation canals, and a striking industrial development. And yet the mercantilist critic of Indian affairs will argue that, because interest charges must be paid to foreign investors of capital, India is being unjustly exploited.

The contention is the more obviously unfounded in view of the circumstances connected with the public debt of India. Of the permanent funded debt, the "ordinary" debt alone imposes a burden on the Indian taxpayer, inasmuch as the interest on the public works debt is charged against the rerenue from railways and irrigation works. Far from being a dead weight on the taxpayer, the railways and irrigation works ordinarily yield a revenue sufficient to meet not only their own interest charges, but also the remaining charge on account of the ordinary debt. For many years, prior to the war, the amount of the ordinary (or unproductive) debt was subject to a process of reduction, the diminution being quite substantial. During the same period, the productive, or public works, debt was rapidly increased. The following table shows the distribution of the total permanent debt between the "Public Works" and "Ordinary" heads. ${ }^{1}$

(Figures denote $\mathfrak{f}$ millions)

\begin{tabular}{|c|c|c|}
\hline & $\begin{array}{c}\text { Ordinary } \\
\text { (Onproductive) } \\
\text { Debt }\end{array}$ & $\begin{array}{c}\text { Publio Works } \\
\text { (Productive) } \\
\text { Debt }\end{array}$ \\
\hline $\begin{array}{l}\text { Calendar Year } 1862 \ldots \ldots \\
\text { March } 31,1902 \ldots \ldots \ldots \ldots \\
\text { March } 31,1907 \ldots \ldots \ldots \ldots \\
\text { March } 31,1912 \ldots \ldots \ldots \ldots\end{array}$ & $\begin{array}{l}76.0 \\
69.2 \\
37.9 \\
33.0\end{array}$ & $\begin{array}{r}2.4 \\
138.6 \\
196.6 \\
238.7\end{array}$ \\
\hline
\end{tabular}

1 "Statement of Moral and Material Progress and Condition of India for 1911-12," p. 162; also ibid. for 1901-02, p. 143. 
No study of the trade balance of India can proceed far without having to take account of the problem of exchange. This problem is especially pressing in the case of India, by reason of the fact that the price of foreign exchange in that country is not only affected, as elsewhere, by the ordinary fluctuations in the relative supply of international debits and credits, but also by the gold price of silver.

The general bearing of Indian exchange upon the foreign trade conditions of that country has been set forth briefly in the Imperial Gazetteer. ${ }^{1}$ The expenditures in Britain on account of India are normally

"defrayed by the sale of Council bills (or telegraphic transfers) by the Secretary of State. Since the exports of India exceed her imports, European importers must remit to India the net value of this excess. For this purpose they buy bills on India, offered by the Secretary of State; the latter pays the home charges with the proceeds, and the buyers send the bills to India, where they are cashed by the Indian Government. As regards the Indian exchequer the result is, therefore, the same as if the amount had been directly remitted to the India Office. Before the Indian mints were closed to the free coinage of silver, the price which the Secretary of State obtained for his bills was determined by the gold value of silver bullion. If bills were offered at a rate less favorable than the market price of silver, importers could adopt the alternative of purchasing bullion and transmitting

${ }^{1}$ Imperial Gazetteer of India, vol. IV, p. 194. 
it to India for coinage. The actual form of the transactions was somewhat more complicated, but the essence was substantially as above. Until 187172 the gold value of the rupee had, except in one year, always exceeded $1 s$. 11d. In 1872-73, it fell to a little over $1 s .103 / 4 d$; and thenceforward, owing to the increasing production of silver, and its reduced employment for monetary purposes due to the currency policy of Germany and other countries, it fluctuated, with a constant downward tendency, until in 1894-5 it reached the lowest point of a little under $1 s .1 d$. As the price of silver fell the Secretary of State obtained worse and worse terms for his bills, or in other words the Government of India had to pay a continually increasing number of rupees to meet the sterling expenditure in England. Thus arose the principal, though not the only, cause of the loss by exchange."

The depreciation of the external value of the rupee had disastrous effects upon India's foreign trade as well as upon her fiscal relations with other countries, notably England. Her revenues were received in India in silver, but her obligations abroad were paid on the basis of gold. By 1893, the gold price of the rupee had fallen to about $35 d$., and, at this price, the value of the rupee for foreign exchange purposes was not over $1 s .2 d$. The financial position of the Indian Government became intolerable, as already suggested, for the loss incurred on the exchange, due to the declining gold price of the rupee, fell ultimately on the Indian taxpayer. India's position as an importing country was also adversely affected, although it is only 
fair to recall that on the side of exports the effect was beneficial. The depreciation of the rupee placed on the importer the necessity of paying more for his goods than their face value in rupees, while, on the other hand, it operated as a bounty to the exporter, inasmuch as he produced his goods in India for rupees and sold them abroad, London for example, for gold, which when brought back to India exchanged for more than its face value in rupees. Moreover, the fluctuations of the exchange, growing out of the varying value of silver, enhanced the risks and uncertainty of trade. The greater unsteadiness of prices which resulted was harmful both to merchants and the public at large. This condition, however, was not, of course, a peculiarly Indian problem. It applies to-day to practically all countries, on account of the abnormal state of the exchanges the world over.

The position became so intolerable that in 1893 the Indian Government took the heroic step of closing the mints to the free coinage of silver. No longer did the gold value of the rupee fluctuate with the gold value of silver bullion. By divorcing the value of the rupee from the value of the metal contained in it, and by regulating the supply of coined rupees, it was possible to bring to an end fluctuations in the exchange value of that coin. By 1899 the Government had succeeded in raising the gold value of the rupee to $1 s$. $4 d$. at which point it remained substantially without variation until 1917.

Before turning to a consideration of the means 
employed in securing this stabilization of the exchange, it may be well to summarize the main features of the Indian currency system, at the outbreak of the war. ${ }^{1}$ The currency of the country consisted of British gold coins, silver rupees, subsidiary coins of silver, nickel, and bronze, and currency notes. The British sovereign and half sovereign were full legal tender for 15 and $71 / 2$ rupees respectively. The Government undertook, under authority of a Notification proclaimed in 1893, to issue rupees to the public in exchange for sovereigns and half-sovereigns at the rate mentioned above, the rate working out at $1 s .4 d$. per rupee. On the other hand, there was no legal enactment compelling the Government to redeem rupees with gold. Yet, as a matter of administrative practice, the Government ordinarily issued sovereigns for rupees or notes in response to a demand from the public. At times, howerer, the practice was suspended. The rupee and the half-rupee, also full legal tender, were the principal medium of exchange. Currency notes of denominations of Rs. 5 and upwards, also circulated and likewise were full legal tender. On presentation at the Currency Offices they were convertible in coin.

${ }^{1}$ In the preparation of this summary and of much that follows the writer has drawn extensively upon the following works:

Keynes, "Indian Currency and Finance." Report of Committee on Indian Exchange and Currency (Cmd. 527), 1920. Mitchell, "The High Price of Silver" and "Silver and the Indian Rupee" in the Journal of the Canadian Bankers' Association, Jan., 1920, April, 1920, respectively. 
As a result of India's favorable trade balance, there was normally existent abroad a steady demand for remittance to that country. This demand was met in part by the importation of bullion and specie, which was unrestricted, and in part by the sale, in London, by the Secretary of State in Council of drafts on the Government of India. "The sale of these drafts, generally known as Council Drafts, was primarily intended to provide funds for meeting expenditure on behalf of the Government of India in the United Kingdom." The effect was to release currency (metallic rupees or notes or, exceptionally, gold) in India against payment in London of sterling. The sales were often extended, in response to the needs of trade, to provide additional currency. While the same result would have followed from the shipment of gold to India and its tender to the Government in exchange for rupees, the acceptance in London of sterling (equivalent to gold before the war) was convenient for both the Government and the purchasers of the Council Drafts.

"Remittance by means of what are termed Council Bills is a feature peculiar to the Indian system," Mr. J. M. Keynes has declared, and it has no parallel elsewhere. ${ }^{1}$ "It arises," he adds, "partly from the historical circumstance that the Government of India is the successor of a trading company, partly from the necessity under which the Government lies of making very large annual re${ }^{1}$ Keynes, "Indian Currency and Finance," p. 102. 
mittances to England." These large payments which the Indian Government must annually make in England, for interest on debt, pensions, government stores, etc., are remitted to England by selling for sterling in London bills which can be cashed in rupees in Calcutta. By this means the Bank of England balance to the credit of the Secretary of State for India is augmented by an amount corresponding to that paid out in Calcutta in rupees by the Government of India upon the presentation of the bills.

The amount of the Council Drafts offered for sale each week in London was governed not only by the requirements of the Secretary of State for India, but also by the current demands for remittance to India. It was, however, subject to the financial ability of the Indian Government to meet the need. Although the price received for the Council Drafts varied from time to time in response to variations in trade demand, it fluctuated very slightly only. The reason, in part, lay in the readiness of the Secretary of State to sell drafts without limit of amount at $1 s .41 / 8 d$. per rupee, which corresponded to the theoretical gold export point. Naturally the price never exceeded this figure. He also maintained the practice of not selling the drafts below 1s. $329 / 32 d$. per rupee. If, however, owing to a change in the normal demands of trade, a tendency showed itself for the exchange value of the rupee to fall below this figure, and if the tendency persisted, the situation was met by the sale of the 
so-called Reverse Councils, at 1s. 3 29/32d. per rupee, bills, that is to say, sold in India and payable in London in sterling.

The effect of these arrangements was to secure the stabilization of exchange very near to the ratio of 15 rupees to the $\ell$. In practice, the outside limits of variation of the sterling value of the rupee were $1 s .41 / 8 d$. and $1 s .329 / 32 d$. The fluctuations which actually occurred were similar to those that normally appear in the exchange between gold standard countries, fluctuations limited by the cost of transporting gold in the adjustment of the balance of indebtedness. The effective maintenance of this fixed relation between the local currency ( $\mathrm{ru}$ pees) and the international currency (gold) depended clearly enough upon the action of the Secretary of State for India in London in giving rupee exchange in return for gold, and of the Government of India in Calcutta in giving sterling exchange in return for rupee currency. The stability of the system depended also in large part upon the maintenance of an adequate reserve fund to support the exchange transactions. Obviously it was necessary to have on hand a sufficient supply of coined rupees in order, at all times, to meet the demand for exchange of international currency for local currency; and sufficient liquid resources in sterling to meet the reverse demand for an exchange of local currency into gold. Two kinds of reserves were therefore necessary, one for each pur. pose. Of the total reserve fund, part was placed 
in London and the remainder in the financial center of India. The precise composition and volume of the fund varied from time to time in response to the varying obligations of the Government and requirements of trade. It consisted, generally speaking, of gold, of money at short notice, and sterling securities. Rupee reserves are also maintained in India.

In the adjustment of India's trade balance the part played by the precious metals prior to the war was only slightly less important than that of Council Drafts. During the five pre-war years 1910-14, for example, the total excess of India's exports over imports of commodities amounted to 261 millions sterling.

This was paid for in a twofold fashion. Funds amounting to 138 millions were imported, representing net sales of Council Drafts (i. e., Council Drafts less Reverse Councils). ${ }^{1}$ There was a further importation of funds in the form of net imports of treasure on private account, amounting to 120 millions sterling, of which 80 per cent was gold. The war at once had the effect of dislocating this normal mechanism of exchange. During the following five years, ended in March, 1919, the excess of merchandise exports, amounting to 254 millions sterling, was liquidated by the import of Council Drafts, to the extent of 100 millions, and by a much reduced import of treasure, amounting to 36 millions. The lessened supply of treasure imported

${ }^{1}$ Report of Committee on Indian Exchange and Currency (Cmd. 527), p. 4. 
naturally placed a heavy burden on the government rupee balances in India.

The outbreak of war gave rise in India, as elsewhere, to a grave situation. Exchange became seriously affected, savings bank deposits were withdrawn, a great demand arose for the encashment of currency notes, and a run occurred on the Indian gold supplies. Although these disquieting circumstances lasted but a short time, and public confidence was gradually restored, the exchange situation continued to remain a source of anxiety, if not perplexity, to the Government.

During the early months of the war the trade of India was adversely affected. Imports and exports alike declined owing, among other causes, to the universal confusion incident to the outbreak of hostilities, to the lack of cargo space, the presence of the Emden in Indian waters, and the abrupt disappearance of Germany as an important buyer of Indian goods. Before long, however, the demand for Indian products began to increase rapidly because of the expanding needs of the belligerent countries in Europe. The excess of merchandise exports, amounting in 1914-15 to only 16 millions sterling, had grown to more than 60 millions by 1917-18. These favorable balances had to be paid for, and it was necessary that they be paid in silver, inasmuch as England and many other countries were unwilling to part with their gold. Negligible quantities only of gold were obtainable, owing to the restrictions imposed by these nations upon its 
export, and silver, therefore, was the only alternative means of payment. But to secure silver the Indian Government was obliged to bid a higher and higher price. The silver rupee, the immemorial medium of exchange of India, was the cash payment desired by the Indian producer in return for his goods. The ancient practice of hoarding was given an impetus at the time, as a result of a simultaneous expansion in exports and decline in imports. The surplus funds were hoarded away. The natural instinct to do so was doubtless stimulated by the many rumors at the time of political instability and military invasions. At all events, the enormous flood of silver coin turned out by the Indian mints disappeared, as it were, down a bottomless pit. Even before the war India normally absorbed a large part of the world's output of silver, taking on the average about 25 per cent of it. In 1917-18 she took 42 per cent, while during the fiscal year which followed she absorbed actually 122 per cent of the world's production for the calendar year 1918 .

In its effort to meet the extraordinary demand for silver for coinage purposes, the Government of India, between April, 1916, and March, 1919, purchased, in the market, over $300,000,000$ standard ounces of silver in addition to $200,000,000$ fine ounces secured under the terms of the Pittman Act. ${ }^{1}$ For the purpose of comparison this may be

${ }^{1}$ Report of Committee on Indian Exchange and Currency (Cmd. 527), p. 8. 
contrasted with the $180,000,000$ standard ounces purchased during an equal period of time, April, 1904, to March, 1907, during which the Indian demand was, for normal times, particularly heavy and continuous.

After the outbreak of the war the demand for silver elsewhere than in India was also increased through the necessity of providing coins for payment of troops, operating especially in Mesopotamia, Egypt, and elsewhere where Indian regiments were largely engaged. Moreover, China, also a silver-using country, was subject to an enhanced demand somewhat similar to that of India. The general increase in the world demand for silver coincided with a notable decline in the world's output of that metal.

As a result of the abnormally large purchases of silver by the Indian Government and the increased demand from other quarters, taken in conjunction with the decrease in the supplies, the price of the metal naturally reacted sharply. Whereas the average price of silver in the London market during the last pre-war year was $279 / 16 d$. per standard ounce, it had exceeded $43 d$. by August, 1917, and by December, 1919, it reached $787 / 8 d$. The peak was attained in February, 1920, at a price of $891 / 2 d$. From that point an abrupt decline occurred, the price on June 13, 1921, being 353/4d.

With the violent increase in the price of silver, the price of the rupee in terms of gold was affected. This in turn affected the exchange between India 
and London. The old ratio of exchange between the rupee and the pound sterling, established in 1893 , of 15 rupees to the $£$, on which basis the rupee was worth $1 s$. $4 d$., was successfully maintained by the Indian Government so long as the fluctuations in the market price of silver were not excessive. Through the use of Council Drafts and Reverse Councils the Government succeeding in "pegging" the rupee for many years at $1 s .4 d$. As soon, however, as the price of silver increased to a point at which the bullion value of the rupee exceeded $1 s$. $4 d$, the continued sale of Council Drafts at the old rate was impossible, except at a loss to the Gorernment. There was also the danger that if the rupee were undervalued, in the official ratio of exchange, it would tend to disappear from circulation through exportation or melting.

As a result it became necessary to raise the price of the exchange. The first of a series of such changes took place on August 28, 1917, when the price of the rupee in Council Drafts was raised to 1s. 5d. Shortly afterwards the Government of India announced that thereafter Council Drafts would be sold at a price based roughly on the price at which silver could be purchased. With the continued increase in the price of silver the rate at which Council Drafts were sold was successively raised to $1 s .6 d$. in April 1918, to $1 s$. $8 d$. in May 1919 , to $1 s$. $10 d$. on August 12, 1919, to $2 s$. on Septemper 15,1919 , to $2 s$. $2 d$. on November 22,1919 , and to $2 s$. $4 d$. on December 12, 1919. 
It was at this juncture, January, 1920, that a report, after prolonged investigations, was issued by a Royal Commission recommending that a new ratio of exchange be established at 10 rupees to the pound, making the rupee worth 2 shillings. The new rate was officially proclaimed in April, 1920. By September of that year the difficulty of maintaining it was so great that it was abandoned, the attempt having cost the Indian Government over $£ 50,000,000 .{ }^{1}$ Thus on September 29, 1920, when the rupee was nominally, or officially, worth $2 s$, its market value was $1 s .51 / 2 d$. A natural result of the effort to enforce the recommendations of the Commission was speculation in exchange. Generally, the market rate was several pence below the government rate for Reverse Councils. As a consequence, there was a rush to purchase these bills of exchange with rupees obtainable in the market at a price below $2 s$. Eventually, the Government abandoned its attempt to stabilize exchange, and left the market to make its own rate. The rate soon steadied at about $1 s$. $7 d$., where it substantially remained during the last months of the year. The general downward tendency continued, however, and on May 23, 1921, the rupee had fallen to $1 s$. $27 / 8 d$.

At the close of 1920 the situation in India, as described by The Times, was marked by commercial embarrassment.

${ }^{1}$ London Times, Annual Financial Review, January 28, 1921. 
"Exporters," it declared, "find little or no market for the produce available. For many months an unabsorbed surplus of a million bales of cotton hung heavily over the Western markets. Jutes, hides, skins, and tea are in poor demand. Importers are still harder hit. The Lancashire textiles which they ordered in such immense quantities at $2 s$. $6 d$. for the rupee, are coming forward for payment with the rupee at $1 s .7 d$. or less. Very heavy losses have been incurred by importers and dealers; goods cannot be cleared, and some of the most substantial houses have found themselves serjously embarrassed."

This condition of commercial depression, however, was of course not to be attributed entirely to the fluctuations in the price of silver and the accompanying dislocation of exchange. In common with other countries, India was bound, sooner or later, to undergo a period of deflation. And since trade does not flourish when prices are declining, it was inevitable that business stagnation, in greater or less degree, should result the world over, India included, with the appearance of deflation. As the downward course of prices is checked, trade, it may be expected, will soon react. It will doubtless gradually be restored to a wholesome and stable condition, attended by a return to normal exchange relations between India and the outside world. 


\section{CHAPTER VI}

THE BALANCES OF TRADE OF AUSTRALIA, NEW ZEALAND AND SOUTH AFRICA

\section{Australia}

Attention was called in the preceding chapter to a contrast between certain features obtaining in the trade balances of Canada and India during the twenty years prior to the war. In Australia, a situation prevailed which was unlike that in either of the other two. During the same two decades, the excess of exports, which in 1892 began definitely to mark the trade balance of the Commonwealth, increased for a time, but later declined, reaching almost the vanishing point in 1912. In 1913 there was a slight import balance. The effect of the war during the early stages was evidently to accentuate this movement, for a considerable excess of imports marked Australian trade during each of the fiscal years 1914-15 and 1915-16. ${ }^{1}$ During the following year, however, a further transition abruptly appeared. This new excess of

* The trade year in the Commonwealth of Australia was altered in 1914. Before that time trade statistics were returned for calendar years. Since that date the trade year has closed on June 30 of each year. 
exports attained record proportions during the year which closed on June 30, 1920.

The general features of the visible balance of trade of Australia are revealed in the statement which follows.

BaLANCE of Trade ${ }^{1}$

(Merchandise, bullion, and specie)

\begin{tabular}{|c|c|c|}
\hline \multirow{3}{*}{ 5-Year Periods } & \multicolumn{2}{|c|}{ Annual Average } \\
\hline & \multicolumn{2}{|c|}{ Recorded Excess of:- } \\
\hline & Imports & Exports \\
\hline 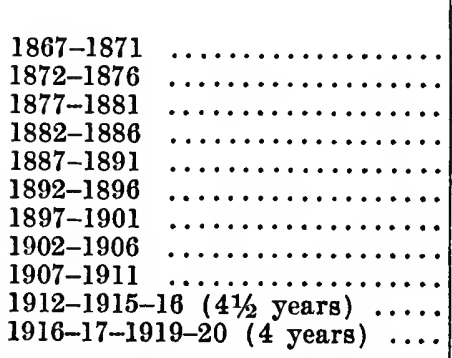 & $\begin{array}{c}\text { E Million } \\
\ldots . \\
\dddot{1} .0 \\
9.0 \\
6.0 \\
\ldots \\
\ldots \\
\ldots \\
\ddot{2.0} \\
\ldots\end{array}$ & $\begin{array}{c}\text { E Million } \\
2.2 \\
1.2 \\
\ldots . \\
\ldots . \\
\dddot{7.4} \\
8.2 \\
15.6 \\
15.2 \\
\ddot{20.6}\end{array}$ \\
\hline
\end{tabular}

1 Australian Official Year Book, No. 13, p. 581.

It would appear from the foregoing that during the ten years following 1902 there must normally have been a balance of invisible items against Australia. The excess of merchandise exports, which between 1902 and 1911 amounted in value to fifteen million pounds a year, may be looked upon as the offsetting factor counterbalancing this excess of invisible debits.

As would be expected, during the earlier years of her career, Australia normally imported goods to 
a greater value than she exported. From 1826, the earliest date for which records are available, onwards, for forty years the balance of trade was marked by an excess of imports. Through the discovery of gold in the fifties an enormous increase took place in both imports and exports. A reaction, however, appeared during the sixties, as a result of a succession of indifferent crop seasons in New South Wales and a decline of alluvial gold mining in Victoria. Subject to these circumstances the labor market became congested, and there arose as a consequence an agitation for a protective tariff to provide employment in manufactures. In the year 1866 the colony of Victoria adopted an act providing protection. It would appear from the trade statistics of the period that the tariff of $\mathbf{1 8 6 6}$ fulfilled one at least of the expectations of its framers, in that it contributed toward reducing the volume of foreign imports. For example, although imports during the five years 1862-66 had an average annual value of nearly $£ 21,000,000$, it was seven years after the passing of the act before imports again reached a total of $£ 20,000,000$. The balance of trade was marked by an excess of exports during the period 1867-75. From that time, however, down to 1892, save in a single year, there was an excess on the side of imports. As mentioned above, a further transition occurred in 1892, the new export balance continuing until 1912, and reappearing in 1916-17. In short, the Australian balance of trade prior 
to 1892 was on the side of imports, save for certain exceptional years in which temporary dislocations of trade intervened. And from that date down to nearly the time of the war an export balance prevailed. The excess of imports in the earlier period represents the introduction of foreign capital for government purposes, as well as for investment in private undertakings. In this respect the experience of Australia is but a counterpart of that of the United States down to 1873, and of Canada prior to 1914. The Australian excess of exports in the later period represents mainly the interest and profit on the earlier investments, repayment of loans to foreign security holders, and also freight charges on overseas trade, which is mainly carried by ships of the United Kingdom and foreign countries. Inasmuch as the introduction of new capital, the interest payments on earlier investments, and other payments on account of shipping and other services are constantly operating in opposite directions at the same time, it follows that in the statistics of trade it is the balance only of these transactions which is reflected in the excess of imports or exports.

While, as is well known, the capital-borrowing countries of the world normally have an excess of merchandise exports over imports, after the earlier stages of borrowing are passed, we nevertheless may count Australia a borrowing nation, notwithstanding the abrupt and rather unexpected disappearance in 1913 of the customary export balance. 


\section{AUSTRALIA, NEW ZEALAND, SOUTH AFRICA 191}

The excess of exports from 1892 onward came to be looked upon as the normal condition.

The change in the ratio of exports to imports, subsequent to 1912, was due mainly, in the opinion of Mr. G. H. Knibbs, the Commonwealth Statistician, to new loans raised in London by the governments of the various states of the country. "The proceeds of these loans, of course, swell the import returns, but, as no immediate payment beyond an installment of interest has to be made in return, the export figures are affected to a very minor degree, until such time as the principal of the debt is repaid." 1

That the various state governments greatly increased their foreign indebtedness about and subsequent to 1912 will be apparent at once from the following statement, which shows that portion of their aggregate public debt payable in London. ${ }^{2}$

\begin{tabular}{|c|c|c|}
\hline & Fiscal Year, ending June $\$ 0$ & Amount \\
\hline $\begin{array}{l}1906 \\
1907 \\
1908 \\
1909 \\
1910 \\
1911 \\
1912 \\
1913 \\
1914\end{array}$ & 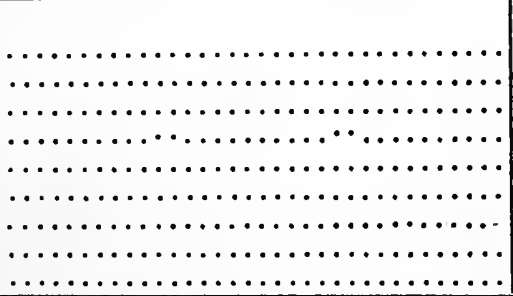 & $\begin{array}{c}£ 1,000 \\
190,887 \\
185,579 \\
183,321 \\
189,410 \\
191,972 \\
189,067 \\
192,190 \\
204,395 \\
224,061\end{array}$ \\
\hline
\end{tabular}

We note from the above table that, whereas the average of the London indebtedness of the several

${ }^{1}$ Australian Official Year Book, No. 10, p. 539.

2 "Summary of Australian Financial Statistics, 1906-1915," p. 21. 
states was approximately $£ 188,000,000$ during the years 1906 to 1911 inclusive, it had increased to $£ 207,000,000$ for the period 1912 to 1914 . Or, stating the case in still another form, it is apparent that while the London indebtedness of the states was increased by $£ 33,000,000$ during the eight years under consideration, $£ 31,000,000$ of this was incurred between 1912 and 1914. This indebtedness, be it noted, was wholly independent of the war, the calculations not proceeding beyond June, 1914.

The change in the ratio between exports and imports, subsequent to 1912 , was also affected to some extent by the introduction of capital incident to a sudden and large increase in the number of immigrants. It will be recalled that in the study of the Canadian balance of trade the capital carried into the country by immigrants formed an important invisible item. Likewise in the case of Australia the ebb and flow of the immigration tides cannot fail to exercise a more or less important influence.

In attempting to construct a balance sheet of the international debits and credits of the Commonwealth, attention will be directed first to the merchandise or visible exports and imports. These are tabulated in the statement, on page 193, for the three years 1911-13.

For the three years under consideration, therefore, the excess of exports had an average annual value of $f 4,000,000$. It is natural to expect to find a roughly corresponding excess of invisible debits.

Prominent among the invisible items are the 
AUSTRALIA, NEW ZEALAND, SOUTH AFRICA 193

Oversea Trade of Australia ${ }^{1}$

(Merchandise, bullion, and specie)

\begin{tabular}{c|c|c|c}
\hline & $\begin{array}{c}1911 \\
£ 1,000\end{array}$ & $\begin{array}{c}1912 \\
£ 1,000\end{array}$ & $\begin{array}{c}1913 \\
£ 1,000\end{array}$ \\
\hline $\begin{array}{c}\text { Exports } \ldots \ldots \ldots \\
\text { Imports } \ldots \ldots \ldots\end{array}$ & $\begin{array}{c}79,482 \\
66,968\end{array}$ & $\begin{array}{c}79,096 \\
78,159\end{array}$ & $\begin{array}{c}78,572 \\
79,749\end{array}$ \\
\hline $\begin{array}{r}\text { Net excess of Ex } \\
\text { ports ....... }\end{array}$ & 12,514 & 937 & $-1,177 \begin{array}{c}\text { (excess of } \\
\text { imports) }\end{array}$ \\
\hline
\end{tabular}

${ }^{1}$ Australian Official Year Book, No. 9, p. 543.

importation into Australia of foreign capital and the payment of interest and dividends to the owners of such capital. In the statement below there is presented the total of the public debts of the various Australian Governments payable in London, during a period of years.

Public Indebtedness of Australia

Payable IN London ${ }^{1}$

\begin{tabular}{|c|c|c|}
\hline Year ended June 30 & $\begin{array}{c}\text { Public Debt of the } \\
\text { Commonwealth } \\
\text { Government }\end{array}$ & $\begin{array}{l}\text { Combined Debts of } \\
\text { the Several State } \\
\text { Governments }\end{array}$ \\
\hline & $\mathfrak{f 1 , 0 0 0}$ & $£ 1,000$ \\
\hline$\ldots \ldots \ldots \ldots \ldots$ & & 191,972 \\
\hline $1911 \ldots \ldots \ldots \ldots$ & 3,815 & 189,067 \\
\hline $1912 \ldots \ldots \ldots \ldots$ & 3,815 & 192,190 \\
\hline$\ldots \ldots \ldots \ldots \ldots$ & 3,646 & 204,395 \\
\hline$\ldots \ldots \ldots$ & 3,510 & $224,06 \mathrm{~T}$ \\
\hline
\end{tabular}

1 "Summary of Australian Financial Statistics, 1906-15," pp. 15, 21.

It is at once necessary to take account of the fact that whereas the trade figures for exports and imports were recorded for calendar years, prior to 1914, the financial statistics, such as those above, are given for fiscal years, ending June 30th. As a 
consequence, allowance must be made for this condition. The estimate of public indebtedness will be computed on the basis of calendar years.

To this end, therefore, it may be assumed that the total at the opening of the calendar year 1911 stood approximately midway between the totals recorded above for June 30th of the years 1910 and 1911. Similarly the figure at the close of the calendar year 1913 may be assumed roughly to have been the average of the totals for the fiscal years 1913 and 1914. Proceeding on this assumption, the London indebtedness of the various State Governments may be estimated to have averaged during the three-year period in question about $£ 200,000$,000. The London indebtedness of the Commonwealth Government averaged nearly $£ 4,000,000$. Loans, moreover, were floated abroad by municipal authorities, although generally not in large amounts. The total of municipal loans current at the end of the year 1913 amounted to $£ 16,000,000 .{ }^{1}$ of this amount, one and a quarter million pounds had been secured from the Federal Government and approximately thirteen million pounds had been raised within the Commonwealth. The balance, therefore, of nearly $£ 2,000,000$ may be looked upon as the measure of foreign indebtedness of the local governments. By combining this figure with that representing the London indebtedness of the Federal and State Governments, we reach the conclusion that for the period in question the aggregate

${ }^{1}$ Ibid., p. 30. Also Australian Official Year Book, No. 8, p. 898. 
AUSTRALIA, NEW ZEALAND, SOUTH AFRICA 195

average foreign indebtedness of the various governing bodies in Australia was about $£ 206,000,000$.

We are in a position now to estimate both the annual public charges payable to foreign lenders in the form of interest and the contraction of new foreign loans on government account. It will be noted from the table above that the London indebtedness of the Commonwealth Government was slightly reduced between 1911 and 1913, whereas for the several states the London indebtedness was increased about $£ 24,000,000$. For the Commonwealth and State Governments, in the aggregate, therefore, the increase was approximately $£ 24$,000,000 . As an average annual increase for the period, 1911-13, this amounted to $£ 8,000,000$. Inasmuch as the net change in the foreign indebtedness of the municipal authorities during that period was of negligible proportions, we may quite fairly accept the figure $£ 8,000,000$ as representing the average annual volume of foreign capital flowing into Australia on government account.

In determining the amount of interest charges due to the foreign owners of capital thus loaned on public account in Australia we revert again to the figure, $£ 206,000,000$, which represents for the period in hand the foreign indebtedness of the various governments of the country. The average rate of interest payable on the Commonwealth public debt, in 1911-13, was somewhat over $31 / 2$ per cent, whereas for the State and Municipal Governments the average of the rates was slightly 
under 4 per cent. ${ }^{1}$ Proceeding on this basis we discover that, for the years under discussion, the annual interest payments abroad by the Federal Government averaged somewhat over $£ 130,000$, while for the other governing bodies of the country the foreign interest charges amounted to about $£ 8,000,000$. The aggregate annual interest payments abroad, therefore, on government account averaged slightly more than $£ 8,000,000$. If we now bring together this debit item representing interest charges and the credit item representing the importation of foreign capital, already estimated at $£ 8,000,000$, we note at once an equivalence. On government account, therefore, during the selected years, Australia was subject to neither a net credit nor debit.

An important item, concerning which unfortunately there is a dearth of official information, is that relating to the importation of foreign capital on private account. It appears from the evidence of Mr. Robert Nash before the Dominions Royal Commission, at Sydney in April, 1913, that the total of British capital invested in Australia amounted in 1912 to $£ 370,000,000 .^{2}$ The quantity of foreign capital other than British invested in Australia is so negligible that we may disregard it. As has been shown above, the total foreign indebtedness of the various governing bodies in Australia

1 "Summary of Australian Financial Statistics, 1906-1915," pp. 15, 23.

2 "Dominions Royal Commission Reports" (Cd. 7171), p. 292. 
amounted in 1912 to about $£ 206,000,000$. Therefore foreign capital privately invested in the country amounted at that time to roughly $£ 165,000,000$. Although the estimate of Mr. Nash was later questioned by Mr. Knibbs, the Commonwealth Statistician, yet, in the absence of official statistics of private investments, we may be justified in accepting the foregoing figures as approximately accurate. Proceeding on this assumption, we find that the average annual interest charge payable abroad on foreign capital invested privately amounted probably to $£ 8,250,000$. Inasmuch as it seemed to be $\mathrm{Mr}$. Nash's opinion that not only was capital on private account not being imported during the years immediately before the war but that it was probably going abroad in the repayment of loans, we shall probably be safe in assuming that during the years 1911-13 the annual importation of foreign capital for private investment did not average more than $£ 200,000$. As a consequence, a net debit, on account of interest payments, appears against Australia of about $£ 8,000,000$ a year.

It has already been mentioned that a considerable increase occurred in the tide of immigration during the years prior to the war. During our selected three-year period the net immigration, or excess of arrivals over departures, amounted to 236,000 persons. This represented an average net increase through immigration of nearly 80,000 per year. In the absence of official information as to the amount of capital carried into Australia by 
immigrants it will be necessary to form an estimate. From the investigations of the immigration authorities in Melbourne in 1912, it appears that the amount of funds carried in by immigrants into the state of Victoria averaged about $£ 9$ per head. ${ }^{1}$ A study by the United States Bureau of Immigration has led to the statement that during the years 1909-13 the per capita amount of capital held by immigrants arriving in the United States from the British Isles was $\$ 82 .^{2}$ This figure, be it noted, represented only the money shown by the newcomers. If the usual settlers' effects had been included, the amount doubtless would have been much larger. The American statement is mentioned on account of its direct bearing on the case in hand, in view of the fact that the great bulk of the immigrants into Australia are from the British Isles. It is, of course, not to be expected that the oversea immigrant into the Commonwealth is so abundantly equipped with capital as is the immigrant into Canada from the American West. Yet, if we take into consideration all who sought a new home in Australia, including both the well-to-do and the impecunious alike, we will probably not be subject to a wide margin of error if we estimate the average per capita holding of capital, including both money and settlers' effects, at $£ 25$. The net credit, therefore, arising out of the introduction of capital through the influx of immigrants may be

1 "Dominions Royal Commission Reports" (Cd. 7171), p. 297.

${ }^{2}$ This statement was contained in a letter to the writer. 
AUSTRALIA, NEW ZEALAND, SOUTH AFRICA 199

estimated at $£ 2,000,000$ a year during our selected period.

Another invisible item is that of private remittances both into and out of Australia. The value of money orders and postal notes issued in Australia during the years $1911-13$ averaged $£ 10,860$,000 a year. ${ }^{1}$ In the same period the money orders and postal notes paid in Australia had an average value of $£ 10,415,000$. It is a fair presumption that the difference between the two represented a balance payable abroad. Thus it formed a net

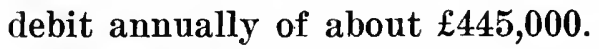

As has been the case with the United States, so with Australia, the service rendered by foreign ships in the carriage of overseas trade has constituted a debit item. A small part only of the foreign trade of the Commonwealth has been carried in Australian-owned vessels. During the threeyear period, 1911-13, the vessels which entered and cleared the ports of the Commonwealth had a total tonnage averaging $10,287,000$ tons per year. ${ }^{2}$ The tonnage of the Australian ships, amounting to 863,000 tons a year, formed slightly less than nine per cent of this total. However, the shipping charges growing out of the transportation of Australian goods in foreign bottoms are for the most part included in the official figures for

${ }^{1}$ Compiled from figures in the Australian Official Year Book, No. 10, p. 701.

" "Summary of Commonwealth Statistics of Transport and Communication, 1906-1916," p. 27. 
imports. This is so because of the fact that "the recorded value of goods imported from countries beyond the Commonwealth represents the amount on which the duty is payable, or would be payable if the duty were charged ad valorem. The value of goods is taken to be ten per cent in advance of the fair market value in the principal markets of the country whence the goods were exported, the increase being intended to represent roughly the insurance, freight, and other charges to the place of landing." 1 No further allowance need be made, therefore, on account of this debit. But inasmuch as other countries are called upon to pay the cost of transporting the goods which they purchase from the Commonwealth, there is a small credit item growing out of the service of Australian ships in carrying Australian exports. There is also a minor credit arising from the sale in Australian ports, to overseas ships, of coal and other ship stores, such articles not being recorded officially under exports. Taking into consideration all of the various factors in the situation, we may place to the account of Australia on the score of shipping a net credit of $\mathfrak{£ 1 , 5 0 0 , 0 0 0}$ a year during the period in question.

Certain minor items we are obliged to disregard, owing to the absence of official figures on which to base estimates, as for example the debit growing out of the expenditures abroad of Australian travelers. This and other such unrecorded items may

${ }^{1}$ Australian Official Year Book, No. 10, p. 535. 
AUSTRALIA, NEW ZEALAND, SOUTH AFRICA 201

be assumed roughly to have balanced. The results may now be presented in tabular form.

Approximate Balance Shemet of austratica

(Figures Represent Annual Averages for the Period 1911 to 1913)

Visible Credits and Debits:

$\boldsymbol{E}$

Average annual excess of visible credits ......4,000,000

Imvisible Credits and Debits:

New capital imported, and interest payments payable abroad on government account: estimated to balance

New capital imported, and interest payments payable abroad on private account: average net debit ... 8,000,000

Capital carried into Australia by immigrants and out by emigrants: average net credit ..........2,000,000

Payments effected through money orders and postal notes: average net debit $\ldots \ldots \ldots \ldots \ldots \ldots \ldots$.

Payments on account of ocean freights, sale of ships' stores, etc.: average net credit ............... 1,500,000

Expenditures abroad by Australians, in the Commonwealth by foreigners, private remittances, etc.: esti-

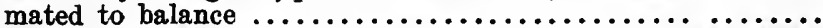

Average annual excess of invisible debits ........ 4,945,000

The discrepancy of nearly $£ 1,000,000$ between the visible credit balance and the invisible debit balance may very fairly be attributed to the margin of error admittedly present in certain of the foregoing estimates.

It has been stated above that the excess of exports attained unprecedented proportions during the fiscal year ended June 30, 1920. Including merchandise, specie, and bullion, this so-called favorable balance amounted to nearly $£ 50,000,000$. Almost at once, however, the position began to undergo change. An extraordinary increase in the value of imports has been accompanied by an actual decline in the value of exports. As a conse- 
quence, the balance of trade during the current fiscal year, which will close June 30, 1921, gives promise of showing an excess of imports, which likewise may reach record proportions. It is estimated that this so-called unfavorable balance will amount to not less than $£ 30,000,000$.

The principal cause of this abrupt change in the Australian trade balance is generally understood to have been the action of British and American manufacturers and exporters in diverting to Australia large consignments of goods, as soon as they discovered that the European, South American, and Eastern markets were largely closed to them owing to adverse exchanges. In part this enhanced inflow of imports represented a belated shipment of goods. During 1919, when trade throughout the world was generally brisk, imports were relatively difficult to obtain. At that time orders by Australian importers were only partially filled by British and other overseas firms. Suddenly, however, with the trade reaction incident to deflation and aggravated exchange difficulties the world over, manufacturers began to supply not only the new orders in full, but orders as well that were in arrears. An accompanying cause of the change in the trade balance has been the decline in exports, growing out of the demoralization of the European wool markets.

In addition to the large excess of imports which has so suddenly made its appearance during the current fiscal year, there are, of course, the in- 
AUSTRALIA, NEW ZEALAND, SOUTH AFRICA 203 visible debit charges, such as interest and freight, which likewise have to be paid for abroad. The result has been an exhaustion of the available funds held in London by most of the Australian banks. This in turn has led the banks to restrict oversea credits, with the further result that importers have been forced to realize as best they can on their stocks through the reduction of prices. With the marketing abroad of Australian wool, wheat, and other exports, the position in London of the Australian banks will become easier.

It will be recalled that one of the factors which rendered an excess of merchandise exports normally necessary in the case of Australia was the payment of interest abroad on foreign, chiefly British, capital. During the years prior to the war the annual interest charges payable in London on government account amounted to about $£ 8,000$,000 . Since 1914 the burden of public debt, as a result of the war, has been greatly increased. At the present time, the interest annually payable on the aggregate public debt of both the Commonwealth and the States amount to $£ 35,000,000$, of which $£ 15,000,000$ is payable abroad, in London. This invisible debit item, of interest on government account, is therefore nearly twice as large as formerly. Accordingly, it would appear that the need of a credit balance of merchandise exports has become correspondingly greater. With the return of normal conditions of trade both at home and abroad, it may be anticipated that the trade bal- 
ance will again come to be marked by an excess of exports.

\section{New Zealand}

The economic history of New Zealand is in large measure epitomized in the growth of the external trade of the country. The expansion of the foreign trade since 1853, the earliest date for which there are official figures, and the general relation between exports and imports are revealed for selected years in the table below.

Imports, Exports, and Total Trade of New Zealand ${ }^{1}$

\begin{tabular}{|c|c|c|c|c|}
\hline & \multirow{2}{*}{ Year } & \multicolumn{3}{|c|}{ Total Value } \\
\hline & & Imports & Exports & Total Trade \\
\hline & & $£ 1,000$ & $£ 1,000$ & $£ 1,000$ \\
\hline $\begin{array}{l}1853 \\
1873 \\
1883 \\
1903 \\
1912 \\
1913\end{array}$ & $\begin{array}{c}\cdots \cdots \\
\ldots \ldots \\
\cdots \cdots \\
\cdots \cdots \\
\cdots \cdots \\
\cdots \cdots\end{array}$ & $\begin{array}{r}587 \\
6,464 \\
6,911 \\
12,788 \\
20,976 \\
22,288\end{array}$ & $\begin{array}{r}303 \\
5,610 \\
8,985 \\
15,010 \\
21,770 \\
22,986\end{array}$ & $\begin{array}{r}901 \\
12,075 \\
15,896 \\
27,798 \\
42,747 \\
45,275\end{array}$ \\
\hline
\end{tabular}

${ }^{1}$ New Zealand Official Year Book, 1917, p. 262.

During the early years of European occupation the exports exceeded the imports. This fact finds its explanation in the weaker bargaining power of the Maori and the temporary residence of the traders. From 1840 on, however, with the permanent settlement of the colony, there appeared an inflation of imports occasioned by the introduction of capital by the colonists, for the purpose of land development. This excess of imports continued without interruption till 1870, although on 
AUSTRALIA, NEW ZEALAND, SOUTH AFRICA 205

a declining scale during the latter part of the period. For two years thereafter, the imports were surpassed by the exports. This temporary excess of exports, however, gave way in 1873 to an import balance, the great increase in imports being due to an enlarged policy of foreign borrowing. The expenditure of borrowed money brought on the land-boom, which led to a general increase of exports as well. Except for the single year 1880, imports continued thereafter to be greater than exports until 1886.

From that date down to the time of the war there was a continued excess of exports save for the two years, 1908 and 1911. This excess of exports was most pronounced between 1886 and 1895. Thereafter the lines representing these trade currents ran almost parallel, as may be seen from the diagram on page 206. It should be borne in mind, of course, that in this chart, in which five-year averages are indicated, the exceptional variations of single years do not appear.

As we should naturally expect, the excess of exports during the last thirty years has served mainly to offset such invisible debits as interest, profits, and other charges on foreign capital invested in New Zealand. There are other debit items, such as private remittances abroad and shipping charges, which would have the effect of swelling the balance of exports. Among the invisible credits the principal ones were the importation of foreign capital for investment and the 
capital carried into New Zealand by immigrants. As regards some of these items there is an absence of official data.

During the three years 1911-13, there was an average annual excess of merchandise exports, or visible credits, amounting to $£ 370,000$. Among the

Quinguennial Averages of Values of Imporids and Exports of New Zealand, 1853 to $1914^{1}$

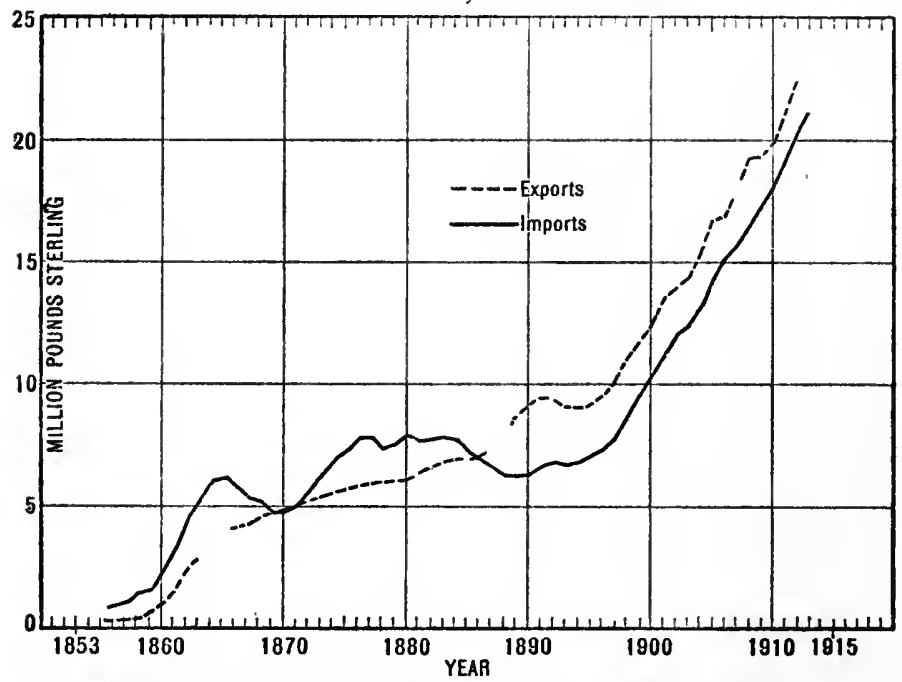

$\therefore$ New Zealand Official Year Book, 1916, p. 250.

invisible items there are two concerning which there is ample information. These are the annual interest payments on public indebtedness, and the introduction of new foreign capital on government account. The amount of interest payable abroad, chiefly in London and in Australia, on the public debt of New Zealand amounted during the years 
1911 to 1913 to about $£ 3,000,000$ a year, while on the foreign indebtedness of the local governing bodies it amounted to about $£ 350,000 .^{1}$ This total annual interest charge of $£ 3,300,000$ on public account was more than offset by the credit growing out of the importation of new foreign capital for government purposes. The aggregate foreign indebtedness of the New Zealand Government and the local governing bodies was increased during the years $1911-13$ by approximately $£ 5,000,000$ per year. On government account, therefore, it would appear that New Zealand during this time was receiving a net credit annually of about $£ 1,700,000$ over and above the interest payments. Bearing in mind the average annual credit balance of $£ 370,000$ on account of merchandise, we reach the conclusion that New Zealand, during the years 1911-13, was subject to a debit balance approximating $£ 2,000,000$ a year on account of private remittances, interest on foreign capital privately invested, shipping charges, and other lesser items.

The trade situation in New Zealand since the close of the war has been very similar to that in Australia. As a result of a very favorable trade balance during 1918 and 1919, a large quantity of funds was accumulated in London to the credit of banks operating in New Zealand. During the early part of the year 1920, however, imports into the country began to increase rapidly. Taking the year as a whole, the result was an excess of im${ }^{1}$ New Zealand Official Year Book, 1917, pp. 242, 672. 
ports amounting to $£ 15,000,000$. In addition to this adverse balance there were various payments, invisible and otherwise, due in London, all of which it was necessary to liquidate. The credit balance in London was soon exhausted as a consequence.

The explanation of the unexpected change in the character of the trade balance during 1920 may be found in the reasons already presented in the case of Australia. The underlying causes were substantially the same in both countries. And, in the main, the commercial recovery will probably proceed in both along generally similar lines. The return to normal conditions will be marked by the reappearance of an excess of exports.

\section{South Africa}

We have in South Africa a country which produces gold as a commodity for export. In such a case naturally there may be a steady outflow of gold as one of the means for the payment of imports. Gold, in fact, stands out as the principal product and export of South Africa. Thus, of the total value of exports, amounting in 1913 to $£ 66$,659,552 , gold alone, with a value of $£ 37,597,000$, constituted over fifty-six per cent. That country occupies a unique position among the civilized nations of the world, in the extent to which it is dependent upon the produce of the mines for its purchases of imported goods. The only country whose position is at all similar in this respect is Mexico, whose exports of copper, gold, and silver 
AUSTRALIA, NEW ZEALAND, SOUTH AFRICA 209

formed during 1913 about fifty-six per cent of the total exports, whereas in South Africa the exports of mining produce amounted in the same year to over eighty per cent of the total.

South Africa has formed an important field for foreign investment. The gold and diamond discoveries resulted in a great impetus to investment. Hundreds of mining enterprises were floated in the years following the discoveries and a large quantity of capital was invested. Mines necessitated railways, and this material development naturally reacted on the growth of population and the general economic expansion of the country.

The balance of trade of South Africa is marked by a pronounced excess of exports. In the statement which follows this appears for the years 1911-13.

Foreign Trade of South Africa ${ }^{1}$

(Merchandise, bullion, and specie)

\begin{tabular}{|c|c|c|c|c|}
\hline & Year & Imports & Exports & $\begin{array}{c}\text { Excess of } \\
\text { Exports }\end{array}$ \\
\hline $\begin{array}{l}1911 \\
1912 \\
1913\end{array}$ & $\begin{array}{c}\ldots \ldots \ldots \\
\ldots \ldots \ldots \ldots \\
\ldots \ldots \ldots\end{array}$ & $\begin{array}{c}\text { £ million } \\
38.0 \\
39.8 \\
42.8\end{array}$ & $\begin{array}{c}\text { f million } \\
57.3 \\
63.3 \\
66.6\end{array}$ & $\begin{array}{c}\text { f million } \\
19.3 \\
23.5 \\
23.8\end{array}$ \\
\hline \multicolumn{2}{|c|}{ Annual Average. } & 40.2 & 62.4 & 22.2 \\
\hline
\end{tabular}

${ }^{1}$ Statistical Year Book of the Union of South Africa, No. 4, 191516, pp. 188, 193.

It would appear that immediately prior to the war a sum of over twenty million pounds was required annually to meet the invisible obligations of South Africa. Or, in other words, the fore- 
going excess of visible credits, averaging $£ 22,200$, 000 a year, may be looked upon as the counterbalancing factor offsetting an approximately equivalent excess of invisible debits.

Undoubtedly the most important of the invisible items in the South African balance of trade is the interest charge payable to foreign owners of capital invested in the country. It was estimated by the London Statist in 1914 that South Africa had been supplied with about $\$ 450,000,000$ of foreign capital, most of which was British. ${ }^{1}$ The interest and dividends due the oversea owners of this capital amounted to more than $£ 20,000,000$ a year. This one invisible debit, therefore, was in itself alone approximately as large as the export balance.

There are two other important invisible items, one a debit and the other a credit, between which there is roughly an equivalence. It has been estimated by the London Economist that the diversion of British capital into South Africa during the years 1911-13 averaged nearly $£ 5,000,000$ per annum. ${ }^{2}$ The offsetting debit, mentioned above, is in the form of shipping charges. In South Africa, contrary to the practice in Australia and New Zealand, imports are recorded on the basis of their value at the place of shipment. ${ }^{3}$ Accordingly

1 The London Statist, May 23, 1914.

2 Compiled from the London Economist by E. Pulsford, "Commerce and the Empire, 1914 and After," p. 65.

s"Dominions Royal Commission Reports" (Cd. 7505), p. 4. 
the cost of ocean transportation is not included in the South African import statistics. It will be recalled that in Australia imports are entered at an increase of ten per cent on their market value in the country of export, for the purpose of including roughly the insurance, freight, and other like charges incident to transportation. It is to be noted that the ship tonnage belonging to South Africa itself is quite negligible and therefore may be left out of reckoning. Accordingly, by adopting the Australian ratio as a working basis, we may compute the approximate shipping charges to be debited against South Africa. Imports into South Africa as shown above had an average annual value of $£ 40,200,000$ during the years 1911-13. Assuming that the various shipping charges roughly amounted to ten per cent of the value of the imports, we may conclude that South Africa was annually subject, in our selected period, to a shipping debit of $£ 4,200,000$. If complete official information were available concerning the other invisible items, such as private remittances both into and out of the country, travelers' expenditures, and the capital holdings of immigrants, we should discover, doubtless, that these various credits and debits would approximately balance. Therefore, we should have remaining a total net invisible debit of something over $£ 20,000,000$ a year, consisting, as we have already discovered, chiefly of interest and dividends on foreign capital invested in South Africa. This debit would be offset by the excess 
of visible exports which, as shown above, averaged for the period in hand twenty-two million pounds per annum.

An agreement was reached during the summer of 1919, between the Bank of England and the gold mining companies of the Transvaal, certain consequences of which we may take account of, because of their bearing on international trade and exchange. The close and mutual relationships between foreign trade, international indebtedness, and exchange rates are illustrated. This agreement removed the restrictions on the export of gold from South Africa which prevailed during the war and thus reëstablished a free market for the gold of that country. During the war the gold producers were under contract to sell their gold to the Bank of England at $£ 3.17 s$. 9d. per ounce. Under the new scheme, which relieved the Transvaal companies from selling their metal at a fixed price and receiving their payment in British currency, they were enabled to send their gold to any market where it might be to their advantage to sell. It thus became possible at once to ship their gold to the United States, and to remit the proceeds to London through the purchase of sterling exchange. By reason of the depreciation of sterling rates in New York, such a transaction became unusually profitable.

The profit in this operation grew out of the discount on sterling exchange. It was announced in the London Times of July 25, 1919, that "already 
an experimental shipment of 50,000 ounces of gold has been made to the United States of America. Owing to the premium which dollars command in relation to sterling, the gold has realized about 85s. 6d. per standard ounce, as compared with $77 s$. 9d. (£3 17s. 9d.) paid to the companies by the Bank of England."

A more detailed statement of the manner in which the profit grew out of the discount on sterling exchange has appeared in the New York Annalist. ${ }^{1}$ When the Transvaal gold miners send their gold to the United States "they get the full United States mint price of $\$ 20.672$ per fine ounce for their fine gold," we are reminded by The Annalist.

"Payment is made in American money, and the amount figures out at the equivalent of $£ 317 \mathrm{~s} .9 \mathrm{~d}$. in London. But, having the money in New York, they are enabled to buy exchange on London, which is also payable in British currency, and they can buy pounds at the rate of exchange and make the difference between the current rate and the parity of exchange.

"In other words, if the Transvaal gold were to be originally figured in dollars, instead of in sterling, the miners under the old agreement, would have to produce $\$ 4,866,500$ in gold before they could get $£ 1,000,000$ in sterling in London. But with exchange at $\$ 4.40$ to the pound, they could export to the United States approximately only $\$ 4,400,000$ in gold and still buy $£ 1,000,000$ in British currency in London.

${ }^{1}$ The New York Annalist, August 4, 1919. 
"Expressed somewhat differently, under the old arrangement of a fixed price in British currency, it took $235,403 \%$ ounces of fine gold to get the $£ 1,000,000$ currency. Now by sending the metal to the United States, selling it to the American mint at the going rate here, and transferring the funds back to London by way of the foreign exchange market, only 212,838 ounces of fine gold would be needed. It would, of course, take a little more to complete the transaction, for there would be the loss of interest while the gold was in transit between South Africa and the United States, and there would be the costs of shipping and insurance. But in gold operations these are minor considerations, especially now that the war is over and there are no more U-boats operating along the shipping channels."

The foregoing is, of course, not to be interpreted as meaning that it was better for sterling exchange that South African gold be sold in New York, as outlined above, than directly to the Bank of England. The ultimate effect upon the sterling rate would have been the same whether a given quantity of gold were disposed of in New York for American currency, with which sterling would then be purchased, or sold, in the first instance, to the Bank of England and then used in paying British debts in New York. The same quantity of gold would ultimately have reached the United States, to contribute toward the reduction of Great Britain's indebtedness. 


\section{INDEX}

Amsterdam, as a financial center, 91

Anderson, B. M., on private loans to Europe, 72

Annalist, The New York, on South African gold to New York, 213

Argentine, trade balance and foreign borrowing, 21

Austin, O. P., on paper currencies, 32

Australia, merchandise balance, $187,188,189,190,192$; transition in trade balance in 1892,189 ; London indebtedness, 190, 191, 192, 194, 203 ; invisible items of balance, 188; interest payments abroad, 190, 195, 196, 203; immigrant funds, 198; private remittances, 199; shipping, 199, 200; trade balance sheet, 201; World War and trade, 203

Balance (equation) of international indebtedness, various elements of, 13 ; relation to merchandise balance, 18,19 , 20,21 ; international trade tends toward equation of indebtedness, $23,24,42,43$; influence upon foreign exchange, $22,34,35,38,39$; balance of payments of United States since the War, 76, 77

Balance of trade, elements of, 14 ; favorable, 4 ; adverse, 14 ; law of, 15; affected by depreciation of currency, 34,35 ,
38,39 ; condition of in Europe in 1917 to $1919,35,36$ Balance sheet, of United States, 63 ; of United Kingdom, 113; of Canada, 130; of India, 164, 167; of Australia, 201

Bastable, C. F., on the stable condition of trade, 5 ; on significance of international loans, 19

"Boarding" Expenses, factor in trade balance, 13, 112

Board of Trade, British, estimate of earnings of merchant marine, 111 ; basis of valuation of imports and exports, 110

Borrowing countries, immature, 8 ; mature, 8 ; their trade balance, 9, 81, 189, 190

British currency, internal and external value, 34

British foreign investments, volume of, 2, 81, 105, 115; geographical location, 106, 107

Cairnes, J. E., on condition of American trade balance, 51

Canada, balance of trade before War, 121, 131; immature borrower before $1914,8,119$; reaching stage of mature borrower, 9, 134, 137; British capital invested in, 120, 122, 132, 133; American capital invested in, 121, 125, 132, 133, 139 ; economic expansion before 1914, 122, 123; invisible items of balance, 125, 136; 
interest and dividends payable abroad, 125; capital of immigrants and emigrants, 126 ; private remittances, 128 ; trade balance sheet, 130 ; trade with United Kingdom and United States, 131, 132; balance of trade during War, 134; foreign borrowings since 1914, 139; gold points in exchange with United States, 142,143 ; war-time fluctuations of New York exchange, 143,145 ; sterling quotations in, 147,148 ; premium on American funds not result of manipulation, 150,151 ; customs regulations and the exchanges, 155,156

Civil War, effect of upon trade, 47 ; effect upon currency and prices, 48; upon American merchant marine, 49

Council drafts, importance in Indian exchange, 173, 177, 178,180 ; purpose of, 174, 177,178

Crammond, E., on invisible credits in British trade balance, 103

Credits, international, invisible and visible, 17 ; equivalence between total debits and, 23, $24,42,43$

Crises, United States, of 1837, 45 ; of $1873,46,47,52$; of $1893,53,54,56$

Currency inflation, and exchange fluctuations, $33,38,39$; its influence on foreign trade, 34 , $35,38,39$

Debits, international, invisible and visible, 17 ; equivalence between total eredits and, 23, $24,42,43$

Depreciated eurrency, influence on rate of exchange, 31,32 , $38,39,151$; influence upon exports and imports, 34,35 , $36,37,38$

Diagrams, Argentine trade balance and foreign borrowings, 22 ; American trade balance and sterling sight rates, 28; the internal and external depreciation of British pound, 36 ; trade balance of United States, 43 ; British balance of trade before $1820,83,84$; British trade balance, 1821 to 1878,99 ; British trade balance, 1879 to 1913,102 ; $\mathrm{Ca}$ nadian trade balance, 1867 to 1921, 135; fluctuations in American exchange rate in Canada, 1910 to 1919,146 ; fluctuations of American exchange in Canada, 1917 to 1921,147 ; Montreal quotations of both sterling and dollar exchange during 1920, 148 ; trade balance of India, 1864 to 1914,171 ; trade bal: ance of New Zealand, 1853 to 1914, 206

Dislocated exchanges, their cause, 31,32

Dutch, The, early eminence of merchant marine, 93, 94, 95; importance as money lenders, 89,90

Economist, London, on British capital in South Africa, 210 Elizabeth, Queen, borrowed capital from Dutch, 88; extended loan to Flanders, 89 ; stimulated growth of British shipping, 94

Emigrants, capital carried from United Kingdom by, 113, 198

Equation of indebtedness always approximated, 24,27

Expenditures abroad by travelers, 13, 55, 62

Exports, visible and invisible, 12 ; under a depreciated currency, $34,35,40,41$; nature 
of bounty on, $33,34,38,39$; influence of exchange fluctuations on Franco-American trade in 1919, 154; method of computing values of, 84

Field, F. W., on Canadian borrowing abroad, 122

Financial center of world moved westward, 87,89

Foreign exchange, relation to balance of trade, $25,26,27$, 152; fluctuations of under normal conditions, 24, 25, 33, $37,152,153$; under depreciated paper, $25,34,35,36$, 37,38 ; effect of fluctuations on trade, bounty on exports, $35,36,38,153,154$, 155; bounty on imports, 34, $35,36,38,153,154,155$; effect of War on exchange rates, 29,31 ; limit of fluctuations of, 29 ; international gold movements and, 30 ; exchange and state of the currency, $32,38,39$; value of exchange and supply and demand, $38,141,153,154$; exchange relations between Canada and the United States, 140,141 ; premium on exchange and its effect, 35,36 , 39,149 ; exchange fluctuations and customs regulations, 155 , 156; Indian exchange situation since $1893,175,176,180$, 184, 185, 186; price of silver and Indian exchange, 174, $175,176,178,179,180,184$, 185, 186; World War and Indian exchange, $180,181,182$, 183

Foreign investment of capital, origin of, 87 ; example of early lending, 88, 89

France, a lending and importing country, 82; exchange on New York during War and effect on trade, 154, 155
Gazetteer, The Imperial, of India, on Indian exchange and trade, 173

General prices, relation to balance of trade, $26,37,41,78$, 151; an automatic check on permanent inflow or outflow of gold, 15, 16; in United States after $1860,47,48$; and specie premium, $35,36,39,41$ Germany, pre-war, an importing country, 82

Giffen, Sir Robert, on the balance of trade, 6; on invisible exports and imports, 16; on earnings of British merchant marine, 110; on British receipt of interest from abroad, 105

Gold, international movement of, and conditions of trade, 25 ; effect, on foreign exchange rate, of suspension of gold shipments, 33 ; gold embargoes and foreign exchange, 31 , 32 ; gold imports into United States during War, 67,68

Gold (specie) points, their operation, 26, 27; cease to function with suspension of free gold movements, 29, 30; in exchange between Canada and United States, 142, 143

Gold (specie) premium, influenced by trade balance, 34 , 38 ; influenced by currency conditions, 35,36 ; its influence upon exports and imports, $34,35,36,39,40,41$, 155

Goschen, Viscount, on exchange fluctuations, under normal conditions, 25; under depreciated currency, 34

Hobson, C. K., on foreign eapital investment, 89,91 ; on private remittances to England, 112 
Holland, important source of capital during seventeenth and eighteenth centuries, 88 , 89,91

Immigrant, remittances, 13,55 , $57,62,71$; capital carried by immigrants entering Canada, 126, 127 ; entering Australia, 198

Imports, visible and invisible, 12 ; under a depreciated currency, 34, 35, 40, 41; under depreciating silver currency, 174,177 ; method of recording, 84

India, merchandise balance of trade, $159,160,180$; mature borrower, 8,9 ; balance sheet of, 164,167 ; dependence on foreign capital, $165,170,171$; invisible debits against, 159 , $160,161,167,169,170$; funded debt of, 166, 172; exchange system before 1893, 174,175 ; exchange system since $1893,175,176,178,179$, 180 ; War and exchange system, 181, 182, 183; currency system, $176,177,178,180$, 181,185 ; exchange stabilized after 1893, 175, 179, 180

Interest payments on eapital internationally invested, 6,7 ; influence of upon trade bal. ance, 5, 6, 9, 19, 20; interest to United States Government by European Governments postponed till 1923, 76, 77

International lending and borrowing, method, 12,13 ; lend. ing countries, mature and immature, 7,8 ; borrowing countries, mature and immature, 8 ; effect on commerce and trade balance, 12, 13, 23

Invisible items in trade balance, 16

Journal of Canadian Bankers Association, on exchange rates and balance of trade between Canada and United States, 143, 144

Keynes, J. M., on Indian exchange system, 177

Knibbs, G. H., on effect of Aus. tralian borrowing abroad, 191

Lending countries, mature and immature, 7,8 ; their trade balance, 9,80

Levi, L., on British balance of trade, 85,100

Litman, s., on American export balance, 67

London Economist, The, on British eapital in South Africa, 210

London Statist, The, on British capital in South Africa, 210

London Times, on Indian commereial outlook in 1920, 185, 186; on sale of South African gold in New York in 1919, 212,213

Mercantile Doctrine, The, 3, 14 Merchandise trade balance, of United States, 58; United Kingdom, 104; Canada, 124, 125; India, 159, 160; Australia, 187, 188, 193; New Zealand, 204; South Africa, 209

Merchant marine, earnings im. portant in British balance, 13, $94,95,110$; important in American balance before $1860,44,45,46$; of United States since War, 65, 70

Monetary Times, The, on effect of Canadian borrowings abroad, 137; on volume of American investments in Canada, 125

Nash, R., on volume of British capital in Australia, 196, 197 
National prosperity and the trade balance, 20

New Zealand, external trade of, 204, 205; balance of trade, 206, 207, 208; invisible items in balance of, 205, 206, 207; trade of since War, 208

Paish, Sir George, on British foreign investments, $3,81,82$, $105,108,116$; on the "'balance of trade," 5 ; on foreign capital in United States, 59; on expenditures abroad of American travelers, 61, 62; on British capital in Canada, 120

Paper currencies, when depreciated the predominant influence on exchange rate, 32 ; bewildering array in Europe of, 32,33

Patterson, E. L. Stewart, on New York as exchange center of continent, 141; on trade balance and exchange between Canada and United States, 143, 144

" Pegged" exchange, sterling pegged at New York, 37, 74; sterling value of rupee pegged, 179,184

Pittman Act, 182

Precious metals, early importance attached to, 14

Premium on exchange, influence upon exports, on imports, 35, $36,38,39,40$; influence in either direction, 34, 38, 39, 155

Reverse Councils, 179, 180, 184 Review of Economic Statistics, on American commerce and the trade balance, $48,49,55$, 61

Roberts, G. E., on capital investments, 83

Rupee, fluctuating value before 1893, 174; influence on Indian trade before 1893,173 ,
175 ; value before 1914 stabilized, 175, 179, 180; value since 1914, 181, 182, 184, 185, 186

Ship earnings, invisible factor in trade balance, $13,19,55$, $65,95,96,110,199,200,207$ Silver, values before 1893,173 , 174,175 ; importance in Indian exchange, $175,176,180$; War and value of, 181, 182, $183,184,185,186$

Smart, W., on importance attached formerly to precious metals, 14

Smith, Adam, on balance of trade, 15

South Africa, gold the principal export of, 208 ; balance of trade, 209; invisible items of balance, 210 ; restrictions removed on export of gold, 212

Specie payments, suspended in United States in 1861, 47, 48; resumed in 1879,53

Specie (gold) points, their operation, 25; cease to function with suspension of free gold movements, 29, 31; in exchange between Canada and United States, 142, 143

Specie (gold) premium, influenced by trade balance, 34,37 , 38 ; influenced by currency conditions, $34,35,39,40$; its influence upon exports and imports, 35, 36, 40, 41, 155, 156 Statist, London, on British capital in South Africa, 210

Sterling exchange, normal course in New York, 27, 28

Taussig, F. W., on effect of free movement internationally of gold, 27; on divergence between general prices and foreign exchange, 40

Times, London, on Indian commercial outlook in 1920,185 , 
186; on sale of South African gold in New York in 1919, 212,213

Todd, J. A., on method and purpose of foreign investment of capital, 12, 13; estimate of British income from foreign investments, 109

Trade balance, reflects net position of country as lender or borrower of capital, 2, 3; views embodied in Mercantile Doctrine concerning, 3 ; transition in balance to eonform to change in conditions, 4,5 , $6,18,20,21$; and national prosperity, 20

Travelers' expenditures abroad, invisible factor, $13,55,57,61$, 62,72

Tucker, Josiah, on foreign trade, 4

United Kingdom, great importing and creditor nation, 80 ; foreign investments of capital, $3,81,82,105,106$; immature lender and mature lender, $7,8,10$; exchange rate on New York, 27, 28; disparity between internal and external value of British pound, 36, 37; overturn in 1823 in trade balance, 84; mode of ascertaining import and export values, $84,96,97$; balance of trade, 85; early lending and borrowing operations, $88,89,92$; investments abroad after 1815, 93; shipping charges against before 1750,93 ; navigation acts, 94 ; invisible items of balance, 95 , 104, 105, 110, 111, 112; large credit balance of invisible items, 97, 116; significance of excess of merchandise imports, 98,100 ; merchandise balance, 1911-13, 107; export of capital, 106, 108; interest receipts from abroad, 104, 105, 107 ; location of British foreign investments, 107 ; earnings merchant marine, 95, 110; official basis of valuing imports and exports, 84; emigrants and capital export, 113; trade balance sheet, 113; War and trade of, 114; loans secured abroad during War, 115, 116; net position as lending country, 118; depreciation of sterling exchange since 1915 , 117

United States, transition in trade balance, $1874,21,52$, 64,119 ; preëminent as exporting nation, 42,77 ; excess of imports before 1820, 44; invisible items of balance, 43 , $49,55,57,58,59,63,70,71$, 75 ; trade balance sheet, 1911 13, 63, 64; early imports of foreign eapital, 59 ; foreign capital invested in, $44,49,50$, $53,54,55,58,61,75$; American capital invested abroad, $61,70,71,73,75$; merchant marine and Civil War, 47; merchant marine and World War, 65, 70; American lending during War, 65, 66, 73; American lending since Armistice, $71,72,76$; balance of indebtedness, 55 ; immature and mature borrower of capital, 8 , $9,10,52$; immature lender of capital since $1917,7,8$; trade balance and World War, 64 , $66,67,73$; gold imports and War, 68 ; reverse movement in securities, 54, 68; government loans and the World War, 69 , 71 ; travelers' expenditures abroad, 55, 57, 61, 70, 72, 78; immigrant remittances, 55,57 , $62,63,70,72,78$

Vanderlip, F. A., on exchange fluctuations, 152 
Walker, Sir Edmund, on Canada's foreign indebtedness, 120,125 ; on interest rate on foreign investments in Canada, 125

War, World, and connection between trade and international lending operations, 1 ; and trade, 31 ; effect on exchange rates, 29, 31; and American trade balance, 64,66 ; British commerce and trade balance, 114; Canadian commerce and trade balance, 134; Indian commerce, 181, 185, 186; Indian currency and exchange,
182, 183, 184; Australian trade, 203; New Zealand trade, 207; gold mining of South Africa, 212

Wells, D. A., on American trade, 50

White, Sir Thomas, on capital carried by immigrants into Canada, $126^{\circ}$

Williams, J. H., on British financial policy, 117, 118

Withers, Hartley, on nature and importance of invisible factors of trade balance, 17, 18; on British trade balance, 98. 


L

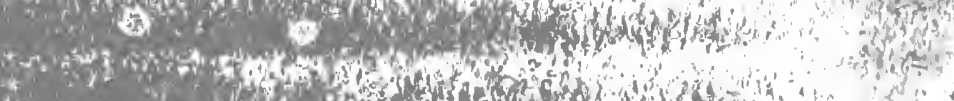

*3. 1. (x)
$\frac{4 y^{2}}{3}$
$+\frac{1}{2}$

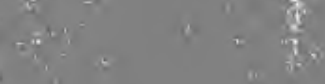
(8)
in
$\log ^{2} \times 2$
$\frac{2}{2}+\frac{1}{2}$
$\log ^{2}$
$\left(\operatorname{lin}_{1} \cdot\right.$

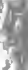
$10 x^{2}=10$
$\log ^{2}+2$
(it)

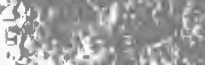

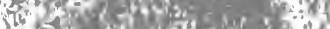

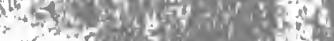

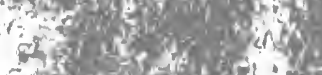

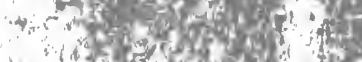

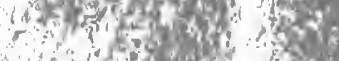
1.20is

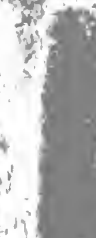
Q6izis

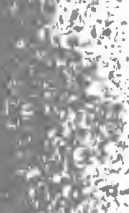
te
325, 15
Nishy
$7 x+35$
$=\frac{4}{24}$
$\therefore$ Fy
$p^{0}: \gamma^{2}$
.
sis
ave
ting
Sillth
ind 0.2
$4^{2} \cdot \mathrm{p}^{2}$
$-4.5 \%$
and

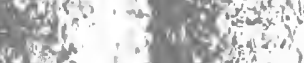

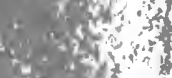
Hit. $x^{2}$

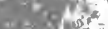
ARE
$102, x^{3} ;$
(a)

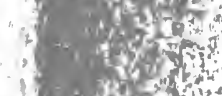

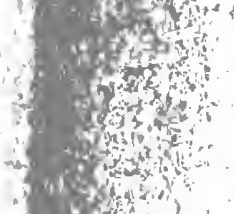

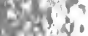
कon:

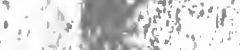
if

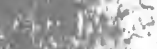

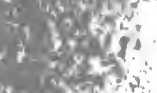

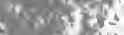
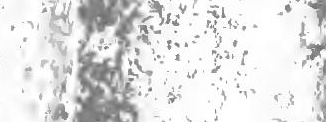
is:
is
P.titit

36

(3)

$\because 11=0$ s

iforom

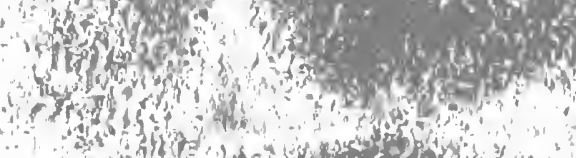

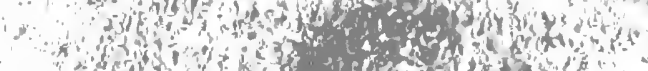

$\left.5 x^{3}\right\}^{2}$

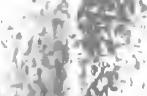

The $1: 1$ तो हो का को a.

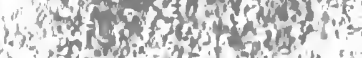
ing in sits

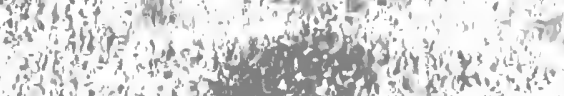




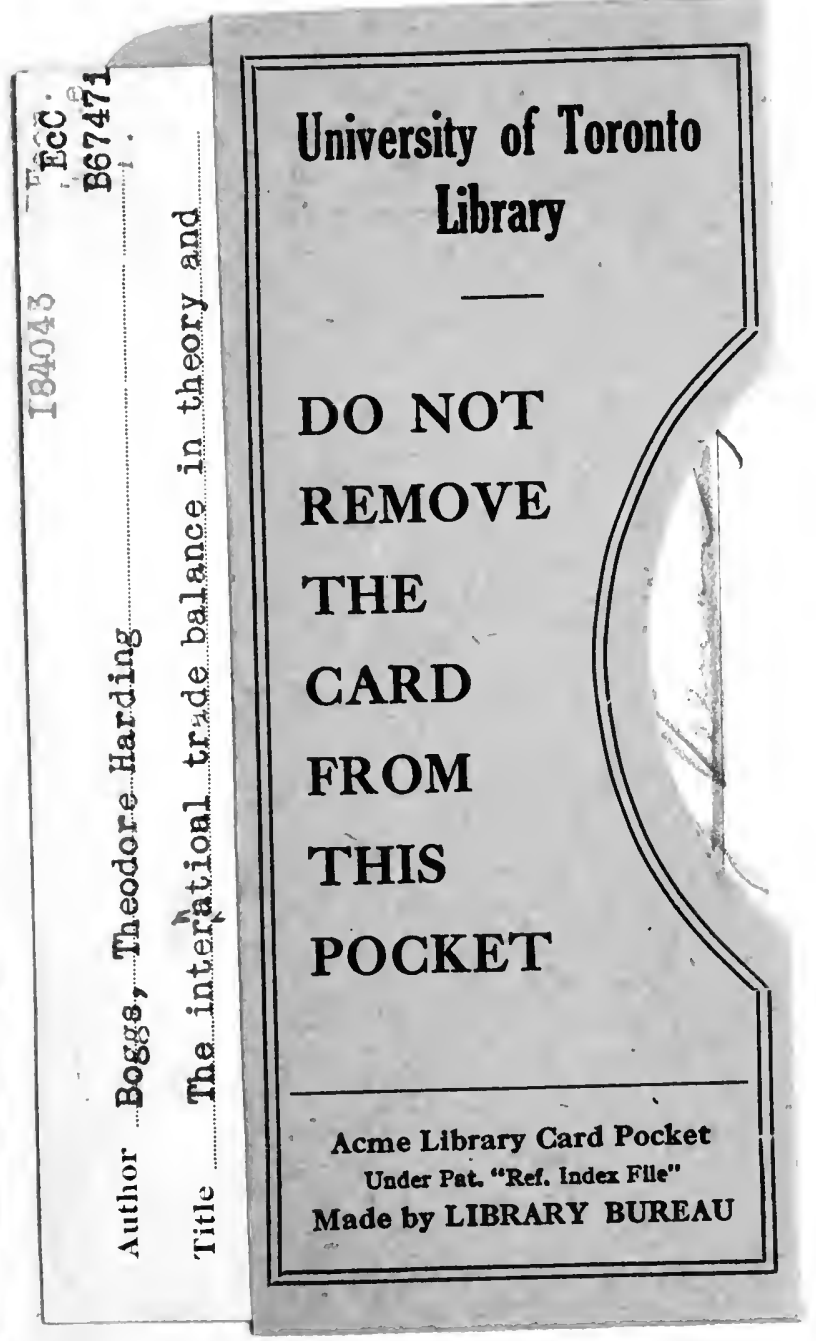




$$
\text { • }
$$

